\title{
ESTUDOS ECOLÓGICOS E GENÉTICOS NUMA PAISAGEM FRAGMENTADA VISANDO SUA CONECTIVIDADE, NO PONTAL DO PARANAPANEMA- SP
}

\section{JOÃO DAGOBERTO DOS SANTOS \\ Engenheiro Florestal}

\author{
Orientador: Prof .Dr. PAULO YOSHYO KAGEYAMA
}

Dissertação apresentada à Escola Superior de Agricultura "Luiz de Queiroz", Universidade de São Paulo, para obtenção do título de Mestre em Ciências , Área de Concentração:: Ciências Florestais.

PIRACICABA

Estado de São Paulo - Brasil

Fevereiro 2002 


\section{Dados Internacionais de Catalogação na Publicação (CIP) DIVISĀO DE BIBLIOTECA E DOCUMENTAÇĀO - ESALQ/USP}

\section{Santos, João Dagoberto dos}

Estudos ecológicos e genéticos numa paisagem fragmentada visando sua conectividade, no Pontal do Paranapanema - S.P. / João Dagoberto dos Santos. Piracicaba, 2002.

$101 \mathrm{p}$.

Dissertação (mestrado) - - Escola Superior de Agricultura Luiz de Queiroz, 2002. Bibliografia.

1. Ecologia da paisagem 2. Ecologia de populaçāo 3. Fragmento florestal 4. Variação genética de plantas I. Título

CDD 634.94 
"Enquanto a cor da pele for mais importante que o brilho dos olhos, sempre haverá guerra !!"

Bob Marley

Dedico a Dona Benedita; mulher, negra e guerreira que me criou.

E à Catarina que me fez reinventar o jeito de viver. 


\section{AGRADECIMENTOS}

Os agradecimentos pela possibilidade da realização deste trabalho são feitos com o mais profundo sentimento ...

- Ao Prof. Paulo Y. Kageyama, pela confiança, pelo exemplo de pesquisador, pelas cobranças e pelo modelo ético e acadêmico.

- Ao amigo P.K.- pelo entusiasmo, pelo tesão em fazer as coisas e pela lealdade....sempre apimentada.

- Ao LCF, local onde fui acolhido e onde construí amizades para uma vida toda.

- Ao LARGEA, local sob domínio de mulheres fortes...onde a convivência é um freqüente aprendizado.

$\bullet$

- A Dra. Fernanda Gaiotto, por me ajudar a mergulhar num mundo novo, o da genética.

- Meus sinceros agradecimentos ao Parque Estadual do Morro do Diado e seus funcionários, fiéis companheiros nas caminhadas na mata e nas escaladas dos emergentes jatobás.

- Ao Pontal do Paranapanema, que me ajudou a enchergar um pouco mais desse Brasil, desigual.

- A minha família, que sempre me deu apoio incondicional nos erros e acertos dessa vida.

- Finalmente, à minha mulher, companheira, amante......Renata, pelo apoio incondicional, pelo sacrifício das noites solitárias, por suportar meu temperamento e por ter gerado a Catalinda (minha cria) !! 


\section{SUMÁRIO}

Página

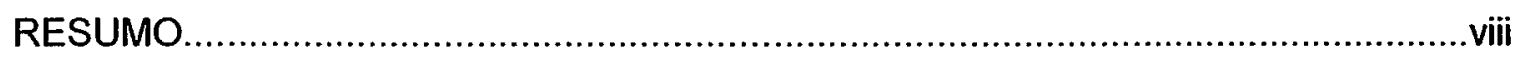

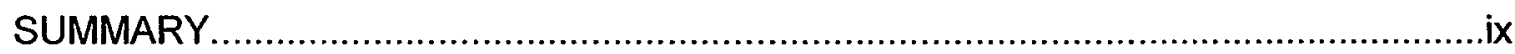

1 INTRODUÇÃO

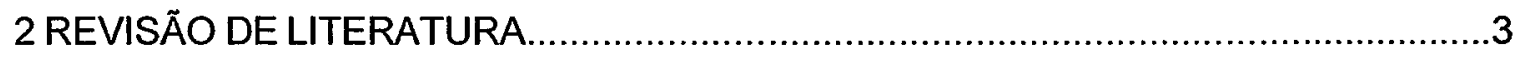

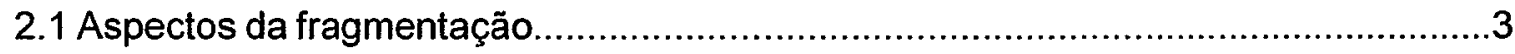

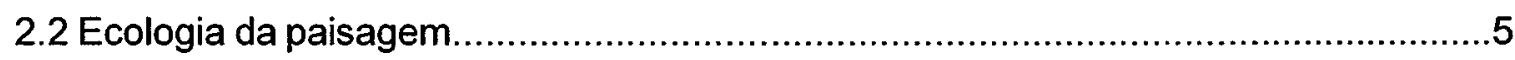

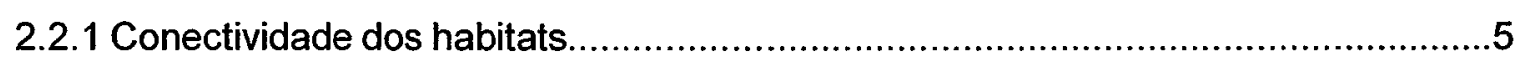

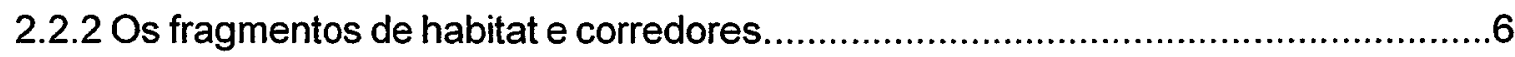

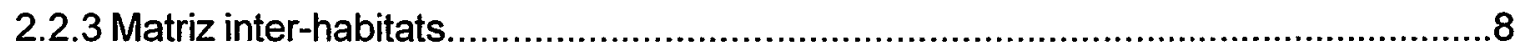

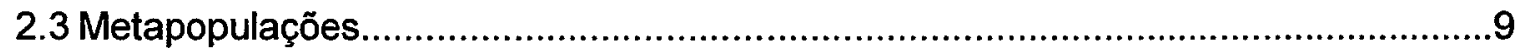

2.4 Conseqüências ecológicas da fragmentação........................................................12

2.5 Conseqüências genéticas da fragmentação.......................................................16

2.6 Variação genética em populações naturais.........................................................19

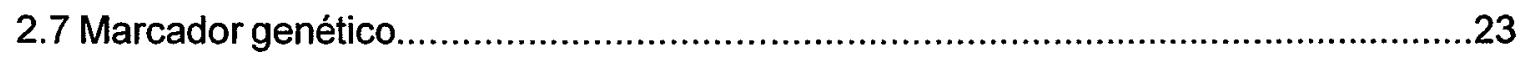

2.8 Diversidade de espécies arbóreas na floresta tropical.........................................24

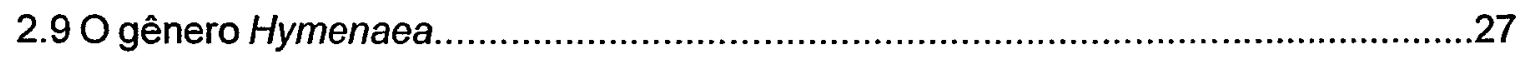

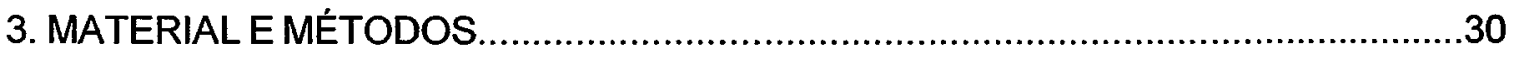

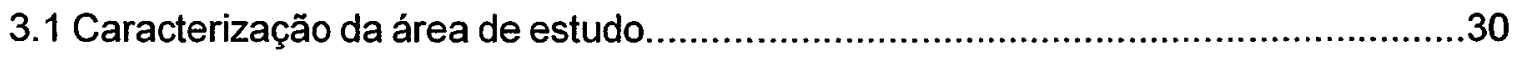

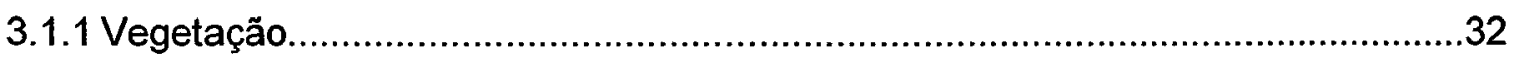




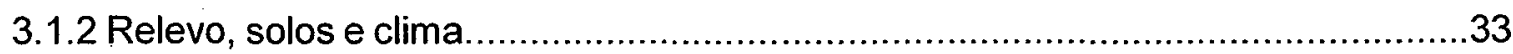

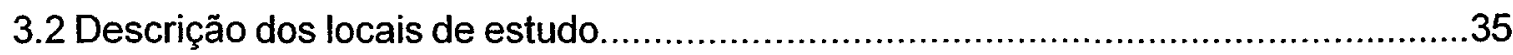

3.2.1 O Parque Estadual do Morro do Diabo (PEMD)...............................................35

3.2.2 Os fragmentos florestais do assentamento rural Água Sumida..........................35

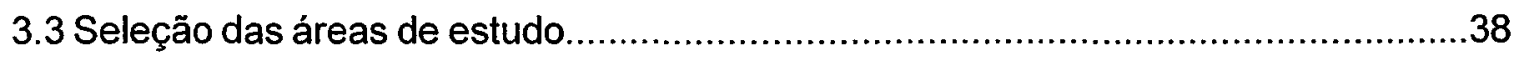

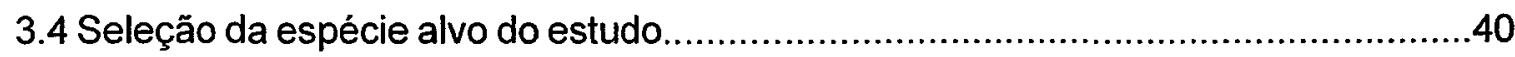

3.5 Levantamento das populações e coleta de material...............................................41

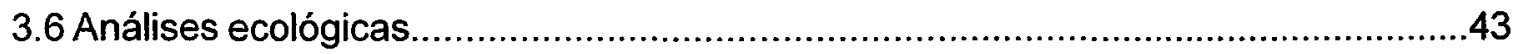

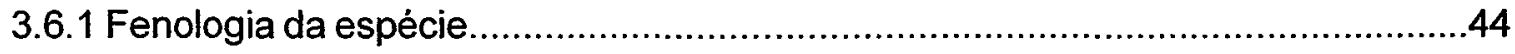

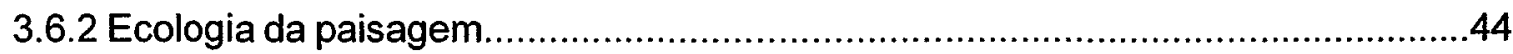

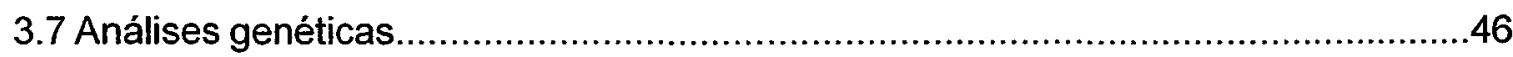

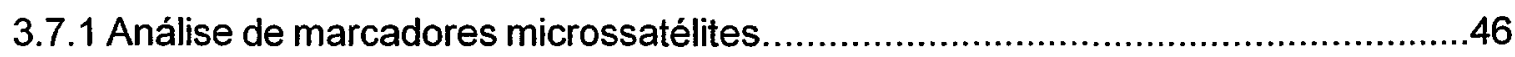

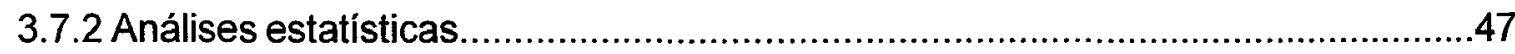

3.7.2.1 Diversidade genética intrapopulacional......................................................

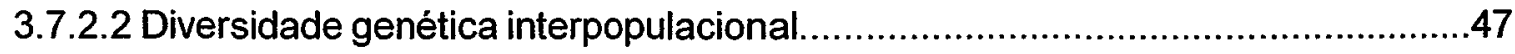

3.7.2.3 Sistema reprodutivo e fluxo gênico...............................................................48

3.7.2.4 Análise de paternidade (fluxo gênico interno)................................................48

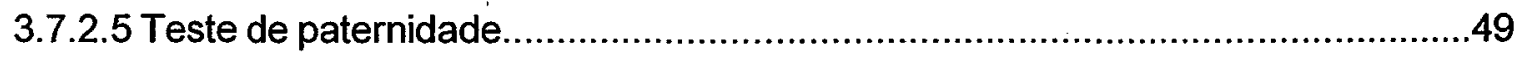

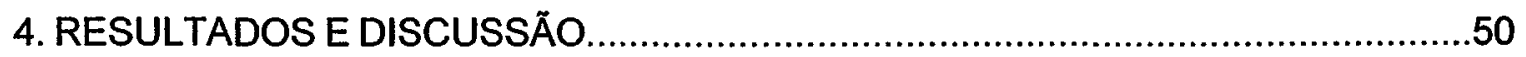

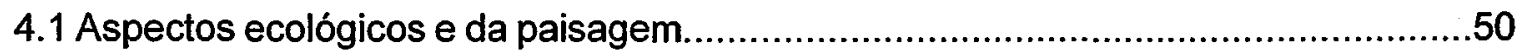

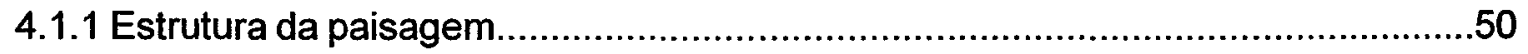

4.1.2 Levantamento do jatobá e distribuição espacial das populações..........................53

4.1.3 Fenologia reprodutiva da espécie nas populações .........................................60

4.1.4 Interações da espécie com a fauna; implicações na dispersão, predação e polinização de Hymenaea courbaril L..................................65 


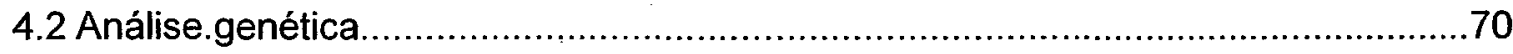

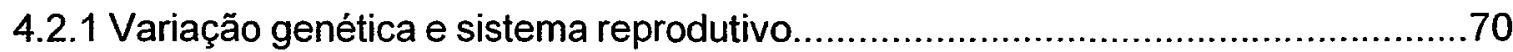

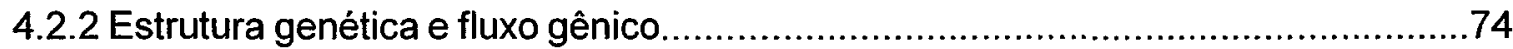

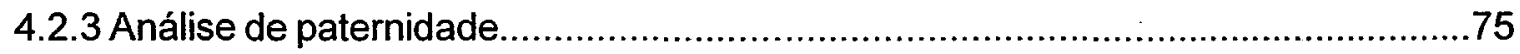

4.2.4 Aspectos relacionados a conectividade funcional e estrutural............................78

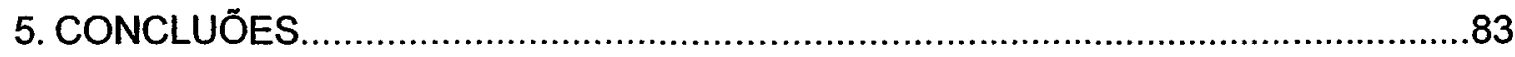

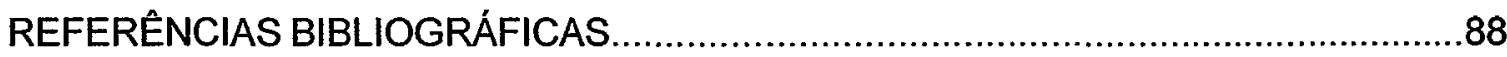




\title{
ESTUDOS ECOLÓGICOS E GENÉTICOS NUMA PAISAGEM FRAGMENTADA, VISANDO SUA CONECTIVIDADE, NO PONTAL DO PARANAPANEMA, SP
}

\author{
Autor: JOÃO DAGOBERTO DOS SANTOS \\ Orientador: Prof. Dr. PAULO YOSHYO KAGEYAMA
}

\section{RESUMO}

Este estudo analisa alguns aspectos da fragmentação florestal em uma paisagem sob domínio da Floresta Estacional Semidecidual no Municipio de Teodoro Sampaio, na região do Pontal do Paranapanema, extremo oeste do estado de São Paulo. O objetivo principal foi examinar as possiveis relações existentes entre as características da paisagem e a estrutura genética das populações contidas nas áreas de estudo, procurando inferir sobre a conectividade estrutural e funcional-e possiveis práticas de manejo da paisagem. Para investigar os efeitos da fragmentação florestal na variação genética de uma espécie de baixa densidade populacional, foram comparados os parâmetros ecológicos e genéticos de 03 (três) populações naturais, uma contida em um fragmento grande e pouco perturbado e outras duas contidas em fragmentos florestais, sendo um médio (553 ha) e outro grande (1175 ha), com diferentes graus de perturbação $\mathrm{e}$ isolamento, representativos dos remanescentes florestais na região. $\mathrm{A}$ área selecionada como fragmento de grande porte e pouco perturbado foi o Parque Estadual do Morro do Diabo. A escolha da espécie alvo do estudo baseou-se em levantamentos florísticos realizados nas áreas dos dois fragmentos, nos quais obtiveram-se as informações sobre a ocorrência e densidade das espécies existentes, onde o jatobá (Hymenaea courbaril L.) foi a escolhida. Nas três populações amostradas realizou-se o acompanhamento da fenologia dos indivíduos amostrados, sendo que no menor dos fragmentos realizou-se um 
censo total das árvores de Hymenaea courbaril existentes, com o objetivo de confirmar os dados do levantamento florístico e para tornar mais precisa a mensuração do fluxo gênico. O acompanhamento dos eventos reprodutivos (florescimento e frutificação) nas três áreas compreendeu 83 indivíduos; onde foram registrados os eventos de flores e frutos durante um periodo de 30 meses, a partir do que foi possivel inferir sobre os possiveis efeitos da fragmentação na fenologia da espécie e possibilitar a avaliação das contribuições relativas dos indivíduos na formação de sementes. Com relação à análise da paisagem, foram calculados os índices de conectividade. As análises genéticas indicam não haver estruturação nas populações de indivíduos adultos remanescentes contidas nos fragmentos analisados, refletindo a estrutura genética anterior à fragmentação. Os dados também demonstram grande número de heterozigotos, sendo que na menor das populações os índices de diversidade genética sugerem um favorecimento, se comparados ás outras duas populações analisadas, aos indivíduos heterozigotos. Registrou-se um alto índice de fluxo gênico por meio de estimativas aparentes e um fluxo real, por meio da análise de paternidade de $7,2 \mathrm{~km}$. Os dados obtidos nesse estudo são compativeis com uma espécie, de final de sucessão, com vetores de fluxo gênico capazes de se deslocar a grandes distâncias e longeva. Esses dados permitem que se façam inferências a respeito de práticas de manejo que visem proporcionar a manutenção das populações de espécies arbóreas raras na paisagem fragmentada do Pontal do Paranapanema. 


\title{
ECOLOGICAL AND GENETIC STUDIES IN A FRAGMENTED LANDSCAPE, "VISANDO" ITS CONNECTIVITY, IN PONTAL DO PARANAPANEMA, SP
}

\author{
Author: JOÃO DAGOBERTO DOS SANTOS \\ Adviser: Prof. Dr. PAULO YOSHYO KAGEYAMA
}

\section{SUMMARY}

This study analyses some aspects of forest fragmentation in a landscape dominated by "Floresta Estacional Semidecidual" in the municipality Teodoro Sampaio, in Pontal do Paranapanema, in the state São Paulo. The study aims to analyze the possible relations between landscape characteristics and genetic structure of plant populations existing in the area. Moreover, it aims to understand structural and functional connectivity. Ecological and genetic parameters of three natural plant populations were compared, in order to investigate the effects of forest fragmentation on genetic variation. These three populations are found in a relatively big and undisturbed forest remnant (Parque Estadual do Morro do Diabo - 35000 ha) and two forest fragments in different degree of isolation and disturbance (one - of $553 \mathrm{ha}$, and one of $1175 \mathrm{ha}$ ) respectively. The tree species Hymenaea courbaril $L$ (jatoba) was chosen for this study based on information about amongst others occurrence and density, which was collected during floristic studies in the two studied fragments,. In the three populations, phenological processes (flowering and fruiting) were observed for in total 83 individuals. over a period of 30 months. - The results were used to estimate the effects of fragmentation on the phenology and to estimate the relative contributions of each individual on seeds production / formation???. As for the landscape analysis,connectivity indices were calculated to estimate the structural connectivity between the three fragments. The structural connectivity was compared to the 
functional connectivity (gene flow). Genetic analyses of remnant adult trees, which can be considered to reflect the genetic structure that existed before fragmentation, show that there isn't a genetic structure within the three populations. . The results also show a high number of heterozygotes. The highest number of heterozygotes was found in the smallest population. The number of heterozygotes in the park was lower than in both the fragments. Analysis of gene flow based on the distribution of genetic diversity among populations showed high values for $\mathrm{N}_{\mathrm{e}} \mathrm{m}$. This was confirmed by the results of paternity analysis, which demonstrated gene flow over $7.2 \mathrm{~km}$. . All data found for this study are for a climax species, that presents a high longevity and have pollinators and seed dispersers able to move over large distances. These data can support sustainable land-use and forest management decisions and the development of specific management practices and techniques to maintain rare tree populations in the fragmented landscape of Pontal do Paranapanema. 


\section{INTRODUÇÃo}

A fragmentação da paisagem tem sido um dos aspectos mais marcantes da alteração ambiental causada pelo homem. No Brasil este processo iniciou-se com a colonização, tendo sido muito acelerado neste século (Dean, 1996). A modificação dos habitats tornou-se uma das principais causas da extinção de espécies e conseqüente perda de biodiversidade.

O manejo efetivo de ecossistemas tropicais para a preservação, conservação e obtenção de recursos florestais deve estar fundamentado em informações biológicas, como estudos em fenologia, biologia floral e reprodutiva das espécies, dinâmica de populações, biologia de sementes, regeneração e genética de populações. Há hoje um certo consenso de que o manejo dos recursos deve considerar a paisagem como um todo (Hobbs,. 1988).

É preciso entender a dinâmica das populações existentes nos fragmentos e sua interação com os elementos da paisagem para que as práticas de manejo e conservação sejam a mais eficiente quanto possivel. Entretanto, pouco se sabe sobre o impacto causado pela fragmentação, sobre a genética e o sistema reprodutivo das espécies arbóreas raras e de outras espécies, assim como das modificações na estrutura populacional e dinâmica dessas populaçōes.

Além disso, existe uma carência de dados ecológicos quantitativos nas florestas do Estado de São Paulo no que diz respeito aos aspectos da dinâmica destas formações, que envolvam estudos temporais de comunidades, estudos de biologia de populações, dos aspectos reprodutivos dessas formações e da sustentabilidade dessas áreas. 
Os poucos remanescentes da formação florestal característica do interior paulista são de grande valor ecológico e taxonômico, funcionando como uma coleção viva de espécies representativas da flora local e de sua diversidade genética, bem como bancos de informações acerca da estrutura e funcionamento deste tipo de ecossistema.

Portanto, existe a necessidade imediata de se desenvolver e adaptar técnicas de restauração de paisagens que promovam o fluxo gênico entre populações isoladas.

As perguntas colocadas são as seguintes: qual o impacto da alteração da densidade das populações, por meio da fragmentação, sobre a manutenção de diversidade genética, a taxa de fecundação cruzada e a movimentação de alelos dentro de populações de espécies arbóreas raras? Haverá um aumento da distância de fluxo de pólen ou um aumento da taxa de autofecundação?

Somados aos diversos aspectos da fragmentação (físicos e biológicos) existe o problema do extrativismo seletivo de diversas espécies arbóreas, onde Hymenaea courbaril (Jatobá) entre outras espécies são exploradas ilegalmente, intensificando os efeitos deletérios nas populações ainda existentes nesses remanescentes.

A hipótese que pode ser sugerida é a de que, mesmo no caso de espécies polinizadas por vetores capazes de se deslocar a grandes distâncias, como o Jatobá, 0 aumento da distância entre indivíduos reprodutivos em áreas isoladas (fragmentos) privilegia o forrageamento de diferentes espécies próximas, ao invés de provocar o deslocamento do polinizador (s) a grandes distâncias para procura de alimento. Sendo assim, haveria um aumento da taxa de autofecundação. Em conseqüência disso, haveria um diminuição no fluxo gênico entre populações isoladas em fragmentos.

Este trabalho tem por objetivo caracterizar a diversidade genética atual e determinar possíveis alterações nos padrões básicos de biologia populacional e ecologia reprodutiva do Jatobá (Hymenaea courbaril L.) em três fragmentos florestais, através da estimativa do fluxo gênico entre e dentro das populações. 


\section{REVISÃO BIBLIOGRÁFICA}

\subsection{Aspectos da fragmentação}

O processo de substituição da vegetação nativa, especialmente da cobertura florestal, ocasionou no interior de São Paulo a fragmentação dos ecossistemas florestais, condicionando-os a pequenas manchas ou fragmentos isolados. A cobertura florestal natural do Estado de São Paulo como um todo ocupa atualmente em torno de $7 \%$ de sua área original (Fonseca, 1998).

Apesar do processo de fragmentação florestal ser bem antigo no Brasil, os estudos que visam a compreensão do comportamento das espécies, do fluxo gênico, da migração e da extinção são bastante recentes.

A fragmentação é basicamente um processo de ruptura na continuidade de habitats naturais e que muitas vezes ocasiona também ruptura dos fluxos gênicos entre populações presentes nesses habitats. A destruição de habitats, e conseqüente fragmentação de populações naturais, tem levado muitas espécies a atingirem uma limitação evolutiva, decorrente da perda de variabilidade genética, que basicamente reduz a habilidade das populações de se adaptarem a mudanças ambientais (Lord \& Norton, 1990; Barret \& Kohn, 1991).

Ellstrand \& Ellan (1993) esclarecem que a fragmentação ocasiona o isolamento populacional, os efeitos de borda, a colonização de espécies exóticas, a diminuição do fluxo gênico e a reprodução entre indivíduos aparentados ou entre menor número de individuos. As principais causas da diminuição do tamanho populacional são a deriva genética e a endogamia. A primeira provoca perda de variação genética e a segunda é responsável pela perda de heterozigosidade. 
O efeito da fragmentação sobre a dinâmica das populações das espécies foi inicialmente estudado levando-se basicamente em conta parâmetros espaciais, sendo a área e o grau de isolamento os dois principais parâmetros estudados. Mais recentemente, com o desenvolvimento da ecologia da paisagem e da teoria de metapopulações, os fragmentos de habitat foram integrados dentro de um contexto mais realista, formado por paisagens heterogêneas, que influenciam a dinâmica de populações e a diversidade de comunidades fragmentadas.

A paisagem é uma unidade heterogênea, composta por um complexo de unidades interativas (ecossistemas, unidades de vegetação ou de uso e ocupação das terras), cuja estrutura pode ser definida pela área, forma e disposição espacial (por .exemplo, grau de proximidade e de fragmentação) destas unidade. A estrutura da paisagem interfere na dinâmica de populações, alterando os riscos de extinção e as possibilidades de deslocamento das populações pela paisagem (Metzger, 1997.). Entretanto, essas abordagens ainda carecem de informações ecológicas que possam possibilitar a compreensão da heterogeneidade ambiental.

Ao ocorrer o processo antrópico de fragmentação do habitat e de ruptura da continuidade da ou das unidades da paisagem (Lord \& Norton, 1990), que representam melhores qualidades de recursos para as populações estudadas (Metzger ,1997), a estrutura da paisagem é modificada. Aliando-se esse a diversos fatores históricos de uso e perturbação, o resultado são mudanças na composição e diversidade das comunidades.

Portanto, a importância das áreas remanescentes de vegetação nativa, como fonte de propágulos, habitat para polinizadores e dispersores, para a manutenção da biodiversidade e para a sustentabilidade das populações naturais (animais e vegetais) ao longo do tempo, torna-se um dos principais pontos a serem considerados.

Sabe-se que a maioria dos remanescentes da Floresta Atlântica está localizada nas encostas, com pouquíssimos remanescentes da região de platôs, onde a expansão agrícola tem resultado em perda de mais de $95 \%$ da cobertura florestal (DEPRN, 1991, SOS Mata Atlântica e INPE, 1993). As florestas Estacionais 
Semideciduais são os ecossistemas mais fragmentados e ameaçados do domínio da Floresta Atlântica.

\subsection{Ecologia da paisagem}

A fragmentação pode ser entendida como o grau de ruptura de uma unidade da paisagem, inicialmente contínua. Este grau de ruptura pode ser medido pelo número de fragmentos ou então por índices baseados na quantidade de borda entre a unidade estudada e as demais unidades da paisagem. Estes aspectos remetem à noção de conectividade, ressaltando, em particular, a importância de corredores e da matriz (Metzger, 1999).

No caso de fragmentos de habitats continentais, a noção de distância a uma área fonte de espécies (o equivalente ao "continente" da teoria das ilhas de MacArthur e Wilson) é muitas vezes inadequad. Neste caso, o isolamento depende das distâncias e das áreas de todos os fragmentos vizinhos, do arranjo espacial dos fragmentos de habitat, assim como das caracteristicas do ambiente entre os fragmentos (Metzger, 1997).

\subsubsection{Conectividade dos habitats}

Metzger (1997), citando diversos autores, sugere que a perda da diversidade num fragmento estaria ligada à disposição do fragmento em relação a outros fragmentos do mesmo tipo (em termos de isolamento, por exemplo) e às características das outras unidades vizinhas.

A conectividade pode ser definida como a capacidade da paisagem de facilitar os fluxos biológicos de organismos, sementes e grãos de pólen (Urban \& Shugart, 2000). Esta definição apresenta um aspecto estrutural e outro funcional. O aspecto estrutural (ou espacial) refere-se à fisionomia da paisagem (Forman, 1983) em termos de i) arranjo espacial dos fragmentos de habitat (considerando, por exemplo, a distribuição de tamanhos dos fragmentos ou o isolamento de fragmentos de um mesmo tipo); ii)densidade e complexidade dos corredores de habitat (que depende, 
entre outros, da frequência e do tipo de interações na rede de corredores, ou do tamanho da malha formada por esta rede); e iii) permeabilidade da matriz(relacionada, em parte, à resistência das unidades da matriz aos fluxos biológicos). Este aspecto estrutural é chamado de conectância ou de conectividade estrutural . O aspecto funcional refere-se à resposta biológica de uma espécie à estrutura da paisagem (Metzger, 1997). A conectividade funcional é uma medida da intensidade da união das sub-populações numa unidade demográfica: a metapopulação (Merriam, 1984) citados por (Metzger, 1997). Ela é avaliada pelos fluxos de disseminação (Opdam, 1991) ou pela intensidade de movimento inter-habitat dos organismos (Merrian, 1984; Taylor et al., 1993). A conectividade estrutural pode ser utilizada para inferir sobre a conectividade funcional (Metzger, 1997).

O conceito de conectividade é essencial na medida em que a sobrevivência de muitas espécies em habitats fragmentados (ou distribuídos de forma heterogênea na paisagem) depende da capacidade destas espécies de atravessarem as unidades da matriz (Metzger, 1999).

\subsubsection{Os fragmentos de habitat e corredores}

O arranjo espacial dos fragmentos de habitat na paisagem pode ser estudado a partir das propriedades de percolação. Diz-se que uma paisagem "percola" quando um fragmento permite a uma espécies, restrita a este habitat, atravessar a paisagem de uma ponta a outra (Turner, 1989).

Os corredores correspondem a estruturas lineares da paisagem que diferem das unidades vizinhas e que ligam pelo menos dois fragmentos de habitat anteriormente unidos (Soulé, Gilpin, 1991; Saunders, Hobbs, 1991). Vários tipos de corredores são distinguidos em função de suas origens (Forman, 1983; Forman, Godron, 1986). Eles podem ser naturais, como, por exemplo, as matas de galeria, ou artificiais, como as cercas vivas. Em paisagens fragmentadas, os corredores são freqüentemente formados por vegetação remanescente (Metzger, 1999). 
Metzger 1997, citando diversos autores, discute a importância dos corredores . Os corredores são reconhecidos por serem essenciais no controle de fluxos hídricos e biológicos na paisagem, em geral facilitando estes fluxos.

Reis (1996) analisa a movimentação de alelos entre as populações de espécies arbóreas, onde essa movimentação é resultado de eventos de polinização elou dispersão dos propágulos a longa distância. Desta forma inclui os eventos relacionados com fluxo gênico, ou alélico, e portanto envolve diferentes modelos ou formas básicas de ocorrência. Estes modelos decorrem principalmente da distribuição geográfica dos indivíduos de cada espécie, predominando, em plantas, os modelos contínuos como o de isolamento por distância e o de alpondras ("stepping stones").

Uma forma de tornar a matriz mais permeável seria aumentando a densidade de "stepping-stones". Os "stepping-stones", chamados de "pontos de ligação" (Metzger, 1999 ), são áreas reduzidas de habitat inseridas na matriz. Assim, considerando uma área florestal como habitat, uma árvore isolada numa paisagem pode ser considerada como um "stepping".

O valor biológico dos corredores depende também das características das espécies e dos tipos de vegetação considerados. Atualmente a maior parte dos estudos existentes consideram principalmente pequenos vertebrados e coleópteros. (Metzger, 1997)

A função dos corredores ainda não está demonstrada em escalas mais amplas e se limita ainda a um número restrito de espécies. Em particular, a importância de corredores para as plantas vasculares é pouco conhecida. (Forman et al.,1986) não evidenciaram um deslocamento continuo das espécies herbáceas, de interior da mata, ao longo dos corredores, mas sim um deslocamento por saltos, supostamente relacionado à disseminação de sementes pelos vertebrados. Esta hipótese é reforçada pelos dados de Van Dorp et al. (1987) que mostraram uma correlação entre a densidade de plantas com sementes e a densidade de aves frugivoras, que, por sua vez, está correlacionada à densidade de corredores na paisagem. Segundo estes dados, a conectividade influencia indiretamente a abundância e distribuição de plantas com sementes, agindo basicamente na locomoção de agentes de disseminação. 


\subsubsection{Matriz inter-habitat}

Derivada da teoria da biogeografia de ilhas: a paisagem é percebida como um conjunto de fragmentos de habitat dispersos numa matriz homogênea e inóspita ( Gilpin, Hanski, 1991). De uma forma mais realista, a matriz é antes de mais nada uma área heterogênea, contendo uma variedade de unidades de não-habitats que representam condições mais ou menos favoráveis às espécies do habitat estudado (Metzger,1999). As unidades da matriz podem, muitas vezes, ser fonte de perturbação e favorecer o desenvolvimento de espécies generalistas, predadoras e parasitas invasoras (Rolstad, 1991) que agem principalmente nas bordas dos fragmentos de habitat e participam na extinção de espécies deste habitat. Desta forma, a matriz-interhabitat inibe em geral os deslocamentos dos organismos do habitat estudado, e esta ação é mais ou menos intensa em função da sua permeabilidade e das capacidades de deslocamento das espécies.

Na regulação da locomoção através da paisagem, os corredores e a matriz têm funções complementares (Metzger, 1999). As espécies que não conseguem se deslocar fora das áreas de seu habitat são favorecidas pela presença de corredores largos. Por outro lado, as espécies que podem se deslocar em outras unidades da paisagem serão mais sensíveis às características da matriz. A permeabilidade da matriz é, desta forma, mais um parâmetro que influi sobre os deslocamentos das espécies na paisagem e pode, consequentemente, influir na probabilidade de extinção de populações fragmentadas. No entanto, observações no campo para avaliação desta relação são ainda escassas (Metzger, 1997).

São muito poucos os estudos sobre o efeito da diversidade da paisagem sobre a dinâmica de populações fragmentadas e, como conseqüência, este efeito é ainda mal compreendido (Metzger, 1997) principalmente para especies arbóreas. 


\subsection{Metapopulações}

O conceito de metapopulação foi originalmente concebido por Levins (1969). Metapopulação é definida como um conjunto de populações conectadas por individuos que se movem entre elas (Hanski, 1991; Hanski, 1997). Terminologicamente o prefixo meta quer dizer além de. Portanto, uma metapopulação é um conjunto de populações, e não de sub-populações. A formação de metapopulações tem sido favorecida pela cada vez mais intensa fragmentação de habitats ; cada população ocorre em um fragmento de mata, por exemplo, dentro de um conjunto de tais fragmentos. No entretanto, metapopulações podem também ocorrer em habitats contínuos, em casos em que a distribuição espacial agregada seja uma característica intrínseca da espécie em questão.

Em uma metapopulação, populações podem ser ganhas por colonização de manchas vazias de habitats e podem ser perdidas por extinção local. Levins (1969, $19970,1974)$ formulou o primeiro e mais simples modelo para lidar com a variação no tempo do número de populações em uma metapopulação.

No modelo de Levins, o tamanho de uma metapopulação é definido como a proporção de manchas ocupadas. Uma metapopulação é pequena ou porque existe poucas manchas com características que permitam que sejam ocupadas ou porque apenas uma pequena fração das manchas existentes está ocupada, apesar de muitas outras serem passiveis de ocupação. No primeiro caso, existe uma restrição do ambiente; no segundo, a própria biologia dos organismos restringe o tamanho da metapopulação. Os conceitos de Levins enfatizam fortemente o ganho e a perda de populações. Conceitos mais recentes de metapopulações têm colocado mais ênfase no padrão especial, ou seja, na existência de várias populações, claramente diferenciadas e ocupando locais distintos, mas havendo ocasionais movimentos de indivíduos entre diferentes populações (Gilpin e Hanski, 1991; Simberloff, 1998). Tais conceitos mais modernos são mais abrangentes que 0 de Levins. Tanto metapopulações altamente fluidas (com freqüentes recolonizações e extinções locais) como conjuntos de populações perenes (que não se extinguem nem colonizem novas 
áreas no tempo ecológico) constituem metapopulações dentro dessa definição, enquanto que apenas o primeiro caso corresponde à visão que Levins tinha de metapopulações.

Em uma revisão de estudos empíricos sobre metapopulações, Harrison (1991) argumenta que o conceito clássico raramente se aplica na natureza. Na visão clássica de Levins, uma metapopulação era composta de conjunto de populações mais ou menos equivalentes em suas probabilidades de colonização e de extinção . Além disso, o modelo de Levins pressupõe que as manchas de habitat são similares em tamanho e fisionomia, o que não acontece na realidade.

Harrison 1991, verificou que a maioria das metapopulações encontradas na natureza encaixam-se melhor em modelos alternativos:

1. Continente-ilha (mainland-island): há uma população dita nuclear maior que nunca se extingue, e que serve de fonte de colonizadores para as populações-satélite periféricas e menores, que se extinguem com freqüência, mas que estão continuamente substituídas por recolonizações

2. Populações em manchas: um conjunto de populações entre as quais movimentos de indivíduos são tão freqüentes que nunca chega a ocorrer extinção. O conceito encaixa-se na definição de metapopuläção dada acima, mas tende em direção ao extremo de população única de um dado contínuo

3. Metapopulação em desequilibrio (non-equilibrium metapopulation): na qual não há fluxo de indivíduos entre os fragmentos; populações são perdidas pouco a pouco por extinção que não pode ser compensada por recolonização. $\mathrm{Na}$ verdade, nesse caso não se trata de uma metapopulação, mas sim de populações relictuais.

Um caso intermediário que combina as primeiras duas situações antes referidas. Há um núcleo formado por um conjunto de populações pequenas, mas conectadas com tanta freqüência que o núcleo como um todo nunca se extingue e 
serve como fonte de recolonização para várias populações periféricas, mais isoladas, que estão sempre se extinguindo e sendo substituídas.

Hanski (1992) apresentou um modelo estocástico simples, no qual explícita a distribuição espacial das manchas de habitat e aplicou-o em metapopulações de borboletas (Hanski, 1994). O modelo é baseado nas funções de incidência descritas por Diamond (1976) e requer dados relativamente fáceis de serem coletados. Apenas a presença ou a ausência de uma espécie é modelada.

A probabilidade de extinção é função da área do fragmento, uma vez que o tamanho populacional depende da área. A probabilidade de colonização é função do número de imigrantes que chegam ao fragmento num intervalo de tempo. Admite-se que número de migrantes que chegam ao fragmento é constante entre intervalos de tempo ou que a variação entre anos é suficiente pequena para ser ignorada. $O$ problema é estimar o número de migrantes que chegam a um fragmento. Hanski continua então assumindo uma visão fenológica de calcular a chegada de imigrantes como função apenas da área do fragmento e da distância entre os fragmentos. A probabilidade de colonização, aqui interpretada como a probabilidade de persistência da população após a chegada no fragmento, é função do número de migrantes que podem atingir um fragmento.

Esse número, por sua vez, depende da distância entre os fragmentos, assim como da área total do fragmento de destino. O modelo pode ser ajustado para dados de presença ou ausência de determinada espécie em um fragmento.

Uma alternativa aos modelos de metapopulação é o chamado sistema fonteescoadouro (source-sink system). Para uma determinada espécie um habitat de boa qualidade ambiental produz um excesso demográfico. Esse habitat é chamado de fonte, onde.habitats pobres têm um déficit demográfico e são chamados escoadouros. As populações que vivem nesses últimos podem não persistir sem migração vinda dos habitat-fonte 
O sistema source-sink é freqüentemente considerado como um caso particular de metapopulação. Realmente comporta os processos de extinção e recolonização e se enquadraria bem no modelo continente-illha.

Entretanto duas diferenças podem ser levantadas, A primeira é o que distingue um habitat-fonte de um escoadouro são características intrínsecas, isto é, um hábitat é considerado bom em virtude de aspectos de recursos, diversidade, etc. Os modelos metapopulacionais não levam em conta as diferenças fisionômicas entre as manchas de hábitat.

A outra diferença é que a extinção das populações sink ocorre de forma deterministica, na ausência de imigração da fonte. No modelo original de metapopulação (de Levins), todas as populações são equivalentes e a extinção ocorre principalmente devido a fatores probabilisticos.

Apenas as taxas de nascimento e morte não são suficientes para determinar se uma população é fonte ou escoadouro (Watkinson e Sutherland, 1995).Além disso, essas taxas não são fáceis de se estimar no campo. Por exemplo, uma população que vive em um ambiente-escoadouro pode ser considera como fonte se for amostrada em um periodo subsequente a uma catástrofe natural. Outro problema é que não é facil determinar o que é um habitat bom para uma determinada espécie.

Outros parâmetros populacionais, como variação da densidade populacional e das taxas de reposição da população, devem, ser utilizadas para essa caracterização.

O conceito de sistema fonte-escoadouro é importante para conservação, podendo fornecer subsidios para a tomada de decisões mais eficazes do que baseadas apenas na teoria clássica de metapopulações. Identificar habitats fonte e priorizar sua conservação é fundamental para a manutenção de populações regionais.

\subsection{Consequências Ecológicas da Fragmentação}

A velocidade dos desmatamentos é sem procedentes na história evolutiva das florestas tropicais e, assim, tem efeitos profundos no ecossistema (Bierregaard et al., 1992). Contudo, os efeitos biológicos e físicos da fragmentação florestal são pouco 
conhecidos. Algumas mudanças são facilmente predizieis, pelo menos qualitativamente.

A floresta tropical tem um papel protetor fundamental no balanço do ecossistema global, regional e local e para a conservação dos recursos hídricos e da biota. As condições microclimáticas poderão sofrer mudanças, principalmente nas bordas, e padrões macroclimáticos locais poderão ser alterados (Kapos, 1989), assim como a composição de espécies; os tamanhos das populações serão reduzidos, o que pode ter conseqüências deletérias (Bierregaard et al., 1992).

Um ponto relevante relacionado com os efeitos da fragmentação florestal refere-se aos agentes de dispersão de propágulos sexuados ou assexuados, seja por ação do vento, de animais ou por mecanismos da própria espécie. O grau com que a fragmentação pode afetar o sucesso da polinização e da reprodução varia amplamente, dependendo de seus polinizadores e da sensibilidade dos mesmos à disjunção do habitat, podendo favorecer algumas espécies de plantas e desfavorecer outras, além de afetar a dinâmica da vegetação e a composição dentro e fora do fragmento.

Conseqüências mais complexas poderão ocorrer devido à fragmentação florestal; por exemplo, mosaicos de habitats incluindo manchas de habitat nativo, fragmentos antropogênicos e áreas agrícolas e urbanas apresentam probabilidades reduzidas de dispersão e estabelecimento de adultos e juvenis de parte da fauna (Santos, 1995), fauna esta responsável por grande parte do fluxo gênico das plantas, ao atuarem como polinizadores e/ou dispersores de sementes.

Terborgh (1990) comparou a densidades de animais que são presas de grandes felinos na floresta de Barro Colorado Island $(\mathrm{BCl})$ - Panamá, onde os grandes predadores foram extintos, com a de Cosha Cashu - Peru, onde há populações preservadas destes, e encontrou valores 10 à 20 vezes maiores para $\mathrm{BCl}$. Terborgh (1990) lembra que, como os grandes predadores necessitam de grandes espaços para encontrar suas presas em número suficiente, eles desaparecerão em florestas fragmentadas à partir de um tamanho mínimo, e isso terá um efeito desestabilizador em populações de consumidores primários, entre eles os predadores e eventuais 
dispersores de sementes, que por sua vez deverá afetar a composição de árvores da floresta.

Diversos estudos analisam as implicações da dispersão de sementes por animais para o manejo da floresta tropical e encontrou que muitas árvores tropicais têm frutos adaptados para o consumo animal, e muitos animais tropicais dependem das frutas para alimento por pelo menos parte do ano; alguns destes sistemas de dispersão mutualistas são pivotais para a comunidade, pois algumas destas árvores frutificam no período de escassez e, assim, mantém espécies de pássaros e mamíferos frugívoros que são vetores para a dispersão e recrutamento de muitas espécies em outras épocas do ano.

Na abordagem clássica sobre fragmentação (Diamond, 1976; Wilson, 1993), onde fragmentos isolados de um determinado tipo de vegetação poderiam ser considerados como equivalentes a ilhas. Existem dois aspectos a serem considerados: em primeiro lugar, nem todas as ilhas estarão necessariamente em equilibrio em relação a um dado grupo de espécies, ilhas na plataforma continental sendo consequência de paisagens afogadas e sua riqueza de espécies podendo resultar de um processo de redução ao invés do equilíbrio imigração/extinção. Outro aspecto é que a denominada "matriz" em torno de um fragmento pode ser ou não equivalente a água que cerca uma ilha $e$, portanto, num mesmo taxon algumas espécies estarão ilhadas e outras . Mesmo neste caso, o grau de isolamento determinado pela matriz possibilitado a existência de gradientes de maior ou menor porosidade para o movimento das diversas espécies. Por outro lado, o isolamento de um fragmento pode levar a uma mudança na composição de uma ou diversas espécies, dependendo, por exemplo, da existência de competidores potenciais na matriz e na necessidade de área minima para a existência de uma dada espécie.

Costa (1992) afirma que quando uma área de floresta é isolada, a importância das espécies arbóreas é ainda mais relevante, pois a continuidade da integridade estrutural e biológica da comunidade depende em grande parte das suas características vitais: organismos fixos, autotróficos e de grande longevidade, que conferem às espécies arbóreas um papel preponderante no ecossistema, já que a presença das espécies arbóreas formando o dossel $e$, consequentemente, os 
microclimas do subbosque ${ }_{2}$ proporciona inúmeros nichos ecológicos, relações mutualísticas e simbióticas à floresta tropical. Por outro lado, por essas mesmas características, é difícil de ser avaliado à curto e médio prazos o impacto do isolamento nas espécies arbóreas dos fragmentos.

Mesmo quando não existe uma população reprodutiva de uma espécies arbórea capaz de mante-la presente na comunidade, o fato não é imediatamente evidente, devido 'a presença de indivíduos adultos daquela espécie; assim uma espécie pode estar efetivamente extinta anos antes da morte do último indivíduo (Costa, 1992).

Os fragmentos florestais de uma região podem dar a impressão inicial que ainda existe uma amostra da comunidade original que irá se perpetuar, mas as mudanças na composição em espécies dos fragmentos provavelmente serão muito grandes. Quase sem exceção, a endogamia forçada, que pode ocorrer pela falta de indivíduos da mesma espécie ou pela falta do agente polinizador, ou ainda pelo cruzamento de indivíduos muito aparentados, resulta em deterioração geral do vigor e o aparecimento de outros efeitos adversos.

Viana et al. (1997), estudando fragmentos florestais do interior do Estado de São Paulo, conclui que: 1) grande parte dos fragmentos são pequenos e isolados; 2) a ocorrência de cipós em alta densidade dificulta a regeneração natural da espécies arbóreas; 3) a freqüência de árvores mortas é alta; 4) o efeito de borda é significativo e complexo e 5) os fragmentos necessitam de manejo para evitar o prosseguimento do processo atual de degradação e perda de biodiversidade.

Metzger (1997) faz uma ampla revisão, onde diversos autores analisam os efeitos da fragmentação na redução da biodiversidade através dos seguintes fatores: Perda de área, Isolamento, distância entre remanescentes, mudança na paisagem , efeito de borda, Extinções Secundária. As conseqüências biológicas da fragmentação da paisagem tem sido consideradas no contexto biogeográfico da habitat e perda de espécies. Entretanto, a fragmentação também resulta em mudanças nos processos ecológicos, resultando em maior degradação do habitat e perda de espécies, sendo tão importantes como as mudanças biogeográficas. 


\subsection{Consequências Genéticas da Fragmentação sobre populações de Espécies Arbóreas}

Em função da alta riqueza de espécies arbóreas da maior parte das florestas tropicais, é importante que se defina quais espécies devem ser consideradas, tomando a população dessas como espécies referência. Para tanto é preciso não só considerar os aspectos demográficos e incluir os parâmetros genéticos dessas populações, já que nem sempre um número grande de indivíduos identifica uma população normal ou geneticamente viável.

Grant (1980) afirma que a entrada constante e alta de genes em uma população através do fluxo gênico é o fator mais importante na manutenção da coesão genética entre as populações de uma espécie. A principal conseqüência da fragmentação florestal no tocante à genética é que as espécies têm sua sobrevivência comprometida devido às alterações nos padrões de troca de genes.

A fragmentação florestal leva a redução do tamanho populacional, criando gargalos genéticos ("bottlenecks"), já que os indivíduos que ficam contem apenas uma pequena amostra do "pool" gênico original. Quando se tem poucas gerações, os resultados observados se devem ao efeito de gargalo genético (Young et al., 1996). Como conseqüência, a pequena população remanescente, caso permaneça isolada por muitas gerações, terá continua perda de alelos devido à deriva genética , diminuindo a variabilidade dentro de populações e aumentando a diferenciação entre populaçōes (Barret \& Kohn, 1991). As conseqüências da deriva dependem do número de gerações que se passaram nos remanescentes.

Tais efeitos apresentam implicações em relação à persistência da espécie. A curto prazo, a perda de heterozigozidade pode reduzir a aptidão individual da espécie, inviabilizando o remanescente populacional. A longo prazo, a redução da riqueza alélica pode limitar a habilidade das espécies a responderem às mudanças devidas à ação de forças seletivas, (Ellstrand \& Ellan, 1993). Outra conseqüência é a depressão 
endogâmica, ou seja, a redução da performance reprodutiva da espécie devida ao cruzamento entre indivíduos aparentados.

Trabalhos que comparem a estrutura genética de populações da mesma espécie em locais com intensidades de perturbação antrópica diferentes ainda são raros.

Souza (1997) estudou os efeitos da fragmentação florestal na variabilidade genética de Chorisia speciosa. A deriva genética ficou evidenciada pela perda, fixação e oscilação aleatória de alelos e também pela alta divergência interpopulacional. Nos fragmentos pequenos e perturbados foram detectados três fenômenos característicos da deriva genética: perda e fixação de alelos e oscilações aleatórias das freqüências alélicas.

Seoane (1998) estudou, através da técnica de eletroforese de aloenzimas, os efeitos da fragmentação florestal na variabilidade genética de Esenbeckia leiocarpa, uma espécie do grupo sucessional clímax, em duas populaçoes contidas em fragmentos florestais. As diferenças encontradas indicam maior homogeneidade nos niveis de fixação alélica das subpopulações do fragmento menor e a homogeneização de sua população. O fluxo gênico é mais intenso entre as duas subpopulações amostradas do fragmento menor, já que está restrito a poucas subpopulações. Assim, quanto menos subpopulações existirem em um fragmento, mais a população estaria sujeita a perda de variabilidade genética, o que poderá comprometer a sobrevivência local da espécie, a longo prazo.

As espécies arbóreas das florestas tropicais são em sua maioria alógamas (Bawa et al., 1984), sendo que a polinização é fundamentalmente realizada por animais (Bawa, 1985b), destacando-se insetos, morcegos e aves. Além do mais, muitas espécies arbóreas tropicais têm dispersão de sementes zoocórica. A fragmentaçao pode impossibiltar que esses agentes se desloquem, alterando o potencial de deslocamento dos genes (fluxo gênico)

As alterações decorrentes da fragmentação contribuem para a erosão da variação genética e aumento da divergência genética por meio do: aumento da deriva 
genética, aumento da endogamia, redução do fluxo gênico e aumento da probabilidade de extinção local, reduzindo a aptidão individual da espécie, podendo inviabilizar o remanescente populacional. (Young at al., 1996).

$\mathrm{Na}$ floresta Estacional Semidecidual, poucos são os exemplos de análise do efeito de fragmentação e perturbação antrópica em populações de espécies arbóreas tropicais.

As predições teóricas indicam que as conseqüências da deriva genética dependem do número de gerações que ocorrem nos remanescentes desde a fragmentação. Por exemplo, as espécies de ciclo de vida curto, tais como as herbáceas, mostram rapidamente grande perda de variação oriunda da deriva. Quando se têm poucas gerações, caso das espécies de ciclo longo (arbóreas), os resultados observados devem-se aos feitos de gargalo genético (Yong et al., 1996).

A perda do vigor decorrente da endogamia é conhecida como depressão endogâmica. A endogamia acarreta uma diminuição dos níveis de variação genética resultando numa baixa taxa de recrutamento e potencial risco de extinção (Hamrick \& Lovelles, 1998)

Muitas espécies possuem meios efetivos de dispersão de genes e com isso mantém altos niveis de variação genética dentro de populações com pouca diferenciação genética entre populaçõe. Entretanto a diversidade genética e estrutura podem ser alteradas se a fragmentação florestal modificar os padrões de dispersão de pólen e sementes (Ballal et al., 1992).

Segundo Souza (1997), a fragmentação de habitats também pode colaborar para modificações no sistema de cruzamento, alterando a composição dos agentes polinizadores ou mesmo em seus comportamentos individuais. Sendo assim, estas mudanças também podem se refletir nos parâmetros relativos aos sistema de cruzamento. 


\subsection{Variação genética em populações naturais}

Hamrick \& Godt (1992) detectaram algumas tendências gerais de variação genética relacionadas a algumas características da história de vida das espécies, com algumas poucas exceções.

Perecim (2000) analisa que, após décadas de estudos em genética de populações de plantas, uma das conclusões mais claras que emergiram desses estudos foi que as espécies diferem muito em seus níveis de variação genética.

- Estrutura genética das Populações

A estrutura genética de uma espécie pode ser definida como a distribuição da variabilidade genética entre e dentro de populações. Esta estrutura resulta da combinação entre mutação, migração, seleção e deriva genética, as quais definem a distribuição da variabilidade genética nas populações. Em populações naturais, a distribuição da variabilidade genética é influenciada pelo modo de reprodução, sistema de acasalamento, tamanho da população, distribuição geográfica e fluxo gênico (Hamrick et al, 1993), além de ser estruturada no tempo e espaço.

Os parâmetros mais utilizados para quantificar a variação genética são as proporções de locos polimórficos dentro de espécies $\left(P_{e}\right)$ e dentro de populações $\left(P_{p}\right)$ e a diversidade geral de espécie $\left(H_{e}\right)$ e de populações $\left(H_{p}\right)$. A distribuição dessa variação dentro e entre populações pode ser estimada pelas estatísticas $\mathbf{F}$ de Wright ou $\mathbf{G}_{\mathbf{S T}}$ de Ney. No entanto, a escala na qual a estrutura genética é considerada é importante, pois diferentes padrões podem ser obtidos dependendo da importância relativa dos fatores que afetam a estrutura genética em determinada escala espacial. Modelos de autocorrelação espacial também podem ser usados para avaliar a estrutura genética de populações ( Slatkin, 1985b).

Para algumas espécies arbóreas tropicais, Hamrick et al., (1993) encontrou que vizinhos próximos têm mais alelos em comum do que aqueles mais distantes, porém a estrutura de família tende a desaparecer nos estágios mais avançados do ciclo de vida. 
Estudos de autocorrelação espacial de Cecropia obtusifolia revelaram uma marcada estrutura genética de plântulas dentro de clareiras, enquanto que esta estrutura foi menos evidente nos estágios de vida mais avançado, embora fosse mantido até a idade adulta (Alvarez-Buylla et al., 1996). Os autores atribuíram esses resultados à limitada ou correlacionada dispersão de sementes. Padrões da estrutura genética local para esta espécie, avaliado por estimativas de $\mathrm{F}_{\mathrm{ST}}$, mostraram que a diferenciação genética entre agupamentos foi alta, sugerindo que a dinâmica de clareiras teve efeito significativo sobre a estrutura genética microespacial da espécie (Alvarez-Buylla et al., 1994). O padrão local desta espécie contrasta fortemente com o padrão macroregional (até $130 \mathrm{Km}$ ), o qual apresentou $F_{\mathrm{ST}}=0,029$, mostrando ausência de estrutura genética (Alvarez-Buylla \& Garay, 1994).

Outro fator de grande importância, que afeta a variação genética e sua distribuição entre e dentro de populações, é o sistema de acasalamento da espécie. $O$ sistema de acasalamento determina o modo de transmissão dos genes de uma geração para outra, o qual pode ser por autofecundação, fecundação cruzada ou misto. A taxa de cruzamento pode influenciar no grau de isolamento entre demes de uma população contínua devido ao seu efeito sobre a área de vizinhança, pois baixas taxas de cruzamento ( $t$ ) reduz a área de vizinhança, enquanto que para $t=1$ essa área é máxima (Crow, 1970).

A relação entre o sistema de acasalamento e deriva genética, principalmente no que diz respeito à depressão por endogamia, é uma importante questão a ser considerada na conservação de recursos genéticos, pois populações pequenas geralmente sofrem endogamia. Endogamia significa o acasalamento de individuos que são relacionados por ascendência , ou seja, diz respeito a homozigotos que possuem alelos idênticos por ascendência. Altos niveis de endogamia não resultam necessariamente em depressão, pois a depressão por endogamia depende principalmente de mecanismos genéticos e da história de vida da espécie (Barret \& Kohn, 1991).

$\mathrm{Na}$ floresta tropical encontra-se muitas espécies dióicas, auto-incompativeis e hermafroditas, o que dá uma idéia de que árvores tropicais são predominantemente de fecundação cruzada (Bawa, 1974). Estimativas da quantidade de cruzamento, para 
muitas espécies arbóreas tropicais, têm revelado altas taxas de cruzamento (Boshier et al., 1995; O'Malley \& Bawa, 1987; O'Malley et al., 1988), porém gêneros amplos tem revelado variação nas taxas de cruzamento entre suas espécies.

- Considerações sobre fluxo gênico

Fluxo gênico é definido por Futuyma (1992) como o intercruzamento entre indivíduos de uma população local e imigrantes de outras populações, sendo que a taxa de fluxo gênico mij de uma população j para uma população i é a proporção de indivíduos que se reproduzem na população $\mathbf{i}$, que imigram da população $\mathbf{j}$, naquela geração. O mesmo autor descreve, também, quatro modelos de fluxo gênico, sendo eles: (i) o de "continente-ilha", no qual ocorre um movimento de genes unidirecional de uma população grande para outra menor e isolada; (ii) o modelo de ithas, no qual a migração ocorre ao acaso entre um grupo de pequenas populações; (iii) 0 de alpondras ("stepping-stone"), em que cada população recebe migrantes somente de populações vizinhas e, (iv) o de "isolamento pela distância", no qual o fluxo gênico ocorre localmente entre os vizinhos, em uma população de distribuição contínua. O mesmo autor ressalta que o fluxo gênico depende não somente da distância de dispersão dos genes, através dos vetores de dispersão de pólen e sementes, mas também das vantagens seletivas ou desvantagens que eles conferem aos indivíduos, pois 0 estabelecimento irá depender do vigor e da viabilidade do zigoto.

O'Malley \& Bawa, 1987; reuniram um conjunto de informações sobre o comportamento de visita dos polinizadores e conseqüente fluxo de pólen em plantas zoófilas, fluxo de pólen em plantas anemófilas, dispersão de sementes e fluxo gênico. Neste estudo os autores citados distinguem as considerações entre "fluxo gênico potencial", que é considerado como a deposição de pólen e sementes à partir de uma população fonte, em função da distância, e o 'fluxo gênico afetivo", que se refere à incidência de fertilização (no caso do pólen) e ao estabelecimento de indivíduos reprodutivos (no caso sementes), como uma função da distância da população fonte. Ainda segundo os mesmo autores, podem haver grandes diferenças entre fluxo gênico potencial e o efetivo. No entanto, as avaliações sobre o movimento de pólen e sementes fornecem valiosas informações para o entendimento da dispersão de genes na natureza, especialmente na ausência de marcadores genéticos apropriados e do 
conhecimento das freqüências gênicas. Os mesmos autores argumentam que com base em dados de dispersão de uma única geração, não considerando a dispersão através do tempo, sendo que as distâncias de dispersão são acumulativas com o tempo, podendo resultar em longas distâncias de dispersão através dos anos.

Uma outra metodologia que vem sendo utilizada recentemente é a análise de paternidade, que fornece uma descrição detalhada da estrutura reprodutiva da população. A resolução desta metodologia é dependente do número de locos polimórficos, do número de alelos por locos, da frequência destes alelos e do número de pais potenciais. Uma vez que o pai de cada progênie está identificado, os padrões de movimento de pólen dentro da área de estudo podem ser determinados, e a proporção de pólen efetivamente oriundo de fora de área de estudo pode se identificada ( Godt \& Hamrick, 1992), os mesmos autores colocam que a análise de paternidade tem, ainda, a vantagem de fornecer uma medida direta da transferência de gametas entre populações, fornecendo portanto estimativas das taxas de fluxo gênico.

Kageyama \& Gandara (1994) ressalta que a distância de vôo do polinizador tem importantes conseqüências genéticas para as populações, pois existem grandes diferenças entre os animais polinizadores quanto ao hábito na visita das flores, o que tem relação direta com a distância efetiva que o pólen alcançaria na floresta.

\section{- Tamanho efetivo das populações}

Na maioria dos casos, o Ne é menor que o número de indivíduos da população $(\mathbf{N})$, o que significa que a representatividade genética é menor quanto menor o $\mathrm{Ne}$. Este é afetado pela densidade populacional, pelo fluxo gênico, pela endogamia, pelas flutuações populacionais, pelas diferentes proporções sexuais e pela variância no número de progênies entre os indivíduos que se reproduzem.

Vencosvsky (1994) propõe um procedimento para estimar o Ne baseado no conceito de Cockerham (1969), utilizando a metodologia de análise de variância dos alelos em cada loco obtidos com marcadores bioquímicos ou moleculares. O método é vantajoso porque, para a sua obtenção, não são necessários conhecimentos prévios do sistema de acasalamento, podendo ser utilizado em casos onde diversos níveis 
hierárquicos foram amostrados e a estimativa pode ser baseada em qualquer número de locos e alelos. $\mathrm{O}$ autor discute dois casos específicos, onde $\mathrm{Ne}$ é estimado para representar a população amostrada ou quando estimamos a representatividade genética da espécie como um todo, supondo a existência de infinitas populações (Vencovsky, 1997).

\subsection{Marcador genético (Microsatélite)}

Atualmente uma série de marcadores moleculares detectam a variabilidade genética baseados na análise de proteínas ou DNA. Segundo Milligan (1994), determinados marcadores nos proporcionam meios para classificar indivíduos em categorias genotípicas nominais. Este tipo de marcadores abrange alozimas detectadas por eletroforese de proteína, RFLP e marcadores de DNA, como RAPD e microsatélites.

Microsatélites ou sequências simples repetidas (SSR- Simple Sequance Repeats) são seqüências presentes em genomas de eucariotos. Marcadores genéticos codominantes, multialélicos baseados em PCR foram observados inicialmente em humanos (Litte Luty, 1989) e nos últimos anos têm sido desenvolvidos para diversas espécies de animais e plantas, explorando o polimorfismo no número de unidades repetidas de di, tri e tetra nucleotídeos. Segundo Ciampi (1999), Microsatélites têm se constituido em uma ferramenta poderosa para análise genética por uma série de características: (1) ocorrência em grande quantidade e distribuição ao acaso em genomas de eucariotos; (2) natureza multialélica e co-dominante; (3) facilidade de detecção via PCR; (4) possibilidade de análise com quantidades limitadas de DNA; (5) possibilidade de transferibilidade dos locos entre espécies do mesmo gênero e às vezes entre familias; (6) possibilidade de intercâmbio de dados com base no compartilhamento de sequências de "primers" entre laboratórios e (7) possibilidade de semi-automatização da análise com uso de "primers" marcados com fluorescência e detecção a laser.Essas regiōes contendo seqüências repetidas têm atraído grande interesse para os estudos de genética de população, por se apresentar altamente 
polimórficas dentro de populações, permitindo realizar estudos de parentesco, fluxo gênico e do nível e manutenção da diversidade genética.

Ciampi (1999), comenta sobre a maior facilidade nos últimos anos no desenvolvimento de marcadores SSR devido às novas estratégias de enriquecimento de bibliotecas genômicas e à rapidez no seqüenciamento automático baseado na fluorescência, e que ainda que o desenvolvimento de marcadores SSR demande tecnologias moleculares refinadas, esse torna-se compensador pela quantidade de informações genéticas que podem ser geradas.

\subsection{Diversidade de espécies arbóreas na floresta tropical}

- Espécies raras na floresta tropical

Gandara (1996) menciona a dificuldade na definição de parâmetros no estabelecimento de reservas para conservação e da escolha de espécies referência para este propósito $\mathrm{O}$ mesmo autor afirma que as espécies raras, ou aquelas que ocorrem a uma baixa densidade, têm sido apontadas como as mais indicadas para este fim pela exigência de grandes áreas para manutenção de suas populações.

A noção de raridade está fundada em causas diferentes: Uma que reflete padrões geográficos naturais de distribuição e padrões e de densidade populacional, outra, que reflete alteraçōes antrópicas ocasionando destruição ou modificação de habitats (Lepsch-Cunha 1996.)

Lepsch-Cunha (1996), analisa a dificuldade de precisar o conceito de raridade, ressaltando a necessidade do entendimento dos tipos de raridade que existem e como as espécies raras diferem uma das outras. A mesma autora distingue 3 caracteristicas que todas as espécies possuem e que se relacionam a: extensão geográfica, especificidade de habitat e tamanho populacional.

Estudos realizados por, com espécies arbóreas arbustivas na ilha de Barro Colorado - Panamá (1500 ha), mostraram que de 409 espécies, somente 306 ocorreram em uma parcela de 50 ha estudada. Os mesmos autores questionaram 
sobre que caracteristicas espaciais fariam com que 103 espécies não ocorressem na parcela, $61 \%$ das espécies que estavam na parcela são listadas como muito raras, Gandara (1995), em levantamento de uma parcela de 400 ha na Amazônia, encontrou que uma das espécies mais raras (Ceiba pentandra -Bombacaceae) ocorria a uma densidade de 1 individuo a cada 33 ha.

Bawa \& Ashton (1991) distingem 4 tipos de raridade em espécies arbóreas tropicais e ressaltam que as conseqüências genéticas dependerão do tipo de raridade.

1. Espécies uniformemente raras, ou seja, espécies que ocorrem tipicamente em . populações com baixa densidade, ou menos que um indivíduo reprodutivo por hectare, geralmente têm mecanismos de dispersão à longa distância de sementes e pólen com fluxo gênico amplo. Existem evidências que muitas são exogâmicas com taxas altas de cruzamento, sendo que a espectativa quanto a raridade à não divergência genética e depreção da variação genética.

2. Espécies que são comuns em alguns lugares e raras em outros. As conseqüências genéticas dependerão grandemente da densidade populacional que prevalece. Reduções de tamanho populacional podem levar à diminuição do nivel de heterozigosidade, a sua permanência por várias gerações pode levar à fixação gênica endogamia e deriva genética aleatória

3. Espécie endêmicas, ou seja, espécies com distribuição geográfica restrita; o tamanho populacional pode ser pequeno ou grande. Quando as populações são grandes, elas devem manter considerável variação genética a não ser que tenham sofrido algum estrangulamento.

4. Espécies com distribuição agrupada, mas que apresentam uma densidade populacional baixa. Se a população for baixa e persistir por várias gerações pode ocorrer perda de variação genética.

Em uma compilação de levantamentos florísticos em florestas tropicais do Estado de São Paulo, Kageyama et al (1991), encontraram que $30 \%$ das espécies arbóreas eram raras (uma árvore por levantamento), $28 \%$ dos indivíduos eram 
pertencentes somente a 3 espécies mais comuns e o restante das espécies se encontrava em freqüências intermediárias.

A raridade é influenciada por 3 aspectos da distribuição espacial: se a extensão geográfica é ampla ou restrita, sobre a amplitude ou restrição da extensão ecológica e se as populações sempre existem em densidade efetiva baixa através de suas extensões geográficas. (Lepsch-Cunha, 1996)

A viabilidade das populações, principalmente das espécies arbóreas raras, sofre muito mais os efeitos da fragmentação (Kageyama et al., 1999; Souza, 1997) podendo por isso essas espécies raras serem consideradas como referências para estudo e monitoramento genético (Kageyama \& Gandara, 1994).

Generalizações quanto às espécies raras ainda não podem ser traçadas, considerando a não delimitação dos diferentes tipos de raridade; constata-se que as amostragem são poucas para detectar padrões nessas espécies, existindo a necessidade de estudos em espaços maiores de tempo e em maior escala geográfica.

Para um ecossistema com altíssimo número de espécies, tal como a floresta tropical, a escolha das espécies para estudo passa a ter cada vez mais importância, principalmente se quisermos extrapolar os resultados para espécies com características semelhantes, fundamentados no conceito de espécies-modelo apresentado por Terborgh (1976). 


\subsection{O Gênero Hymenaea}

O gênero Hymenaea L. pertence à familia leguminosae, sub-familia Caesalpinioideae, tribo Detarieae.

$\mathrm{Na}$ última revisão sobre o gênero são descritas 14 espécies, a maior parte delas com distribuição neotropical, estendendo-se desde o centro do México, Antilhas, até ao norte da Argentina (Lee \& Langenheim, 1975). Acredita-se que o centro de origem do grupo tenha sido na África, e o de diversidade na região Amazônica (Langenhein \& Lee, 1974; Lee \& Langenheim, 1975).

Apesar dos inúmeros estudos tanto ao nivel puramente químico, como taxonômico, a delimitação dos taxa nem sempre é simples. Algumas espécies apresentam uma grande variação morfológica sobretudo em certas áreas de suas distribuições. Algumas destas variações foram consideradas suficientemente estáveis ao ponto de se criarem variedades dentro de uma espécie. Em outros casos, certos taxa, anteriormente considerados espécies boas, passaram à categoria de variedade de uma espécie mais ampla. Esse é o caso de $H$. stilbocarpa Hayne, $H$. altissimi Ducke e $H$. longifolia Benth, que foram incluídas como variedades de $H$. courbaril L. (Rocha ,1988).

Todas as espécies do gênero têm hábito arbóreo; sendo que o porte varia consideravelmente, desde árvores de menos de $3 \mathrm{~m}(H$. stigonocarpa) até individuos emergentes com mais de $40 \mathrm{~m}$ em Mata Atlântica ( $H$. coubaril var. altissima). Entretanto, diversas espécies apresentam considerável variação de porte, entre localidades diferentes, e de acordo com condiçőes locais particulares.

As diversas espécies de Hymenaea ocorrem em uma diversidade de habitats e comunidades que variam desde Floresta Ombrófila Densa $(H$. courbaril, $H$ ablongifolia, $H$. intermedia, H. parvifolia) até Cerrado $(H$. stigonocarpa, $H$. martiana) e Caatinga $(H$. eriogyne). 
Do mesmo modo, a extensão de suas distribuições geográficas também é muito variável, desde uma espécies ( $H$. courbari) que abrange praticamente toda a extensão americana do gênero, até várias espécies de distribuição restrita e fortemente endêmicas ( $\mathrm{H}$. torrei, $\mathrm{H}$. aurea, $\mathrm{H}$. rubriflora, $\mathrm{H}$ velutina), de acordo com os registros existentes (Lee e Langenheim, 1975).

Para este estudo, os indivíduos foram classificados como Hymenaea courbaril Linnaeus var. stilbocarpa (Hayne) Y.T. Lee \& Langenheim. Esta variedade é encontrada desde o Paraná até a Bahia e Goiás; e segundo alguns autores alcança até - Piauí. Comumente ocorre em capões de mata seca (ou mesófila) semidecídua, considerada por vários autores como espécie característica desta formação .

Trata-se de árvore perenifólia a semicaducifólia, podendo atingir até $\mathbf{2 5}$ metros de altura e $120 \mathrm{~cm}$ de DAP, com tronco reto, cilindrico e fuste com até $15 \mathrm{~m}$ de altura. Apresenta ramificação racemosa, irregular; copa grande e arredondada, com folhagem densa. Possui casca externa cinzenta-clara, quase lisa a áspera, com pequenos sulcos superficiais; e espessa com até $10 \mathrm{~mm}$. A casca interna é rosada, e exsuda resina cor de vinho. Suas folhas são alternas, compostas, coriáceas, brilhantes, com dois folíolos, de bases desiguais e com até $12 \mathrm{~cm}$ de comprimento por $5 \mathrm{~cm}$ de largura. As flores são hermafroditas, brancas e creme, reunidas em corimbo, tendo em média 14 flores terminais. $O$ fruto é do tipo vagem lenhosa, indeiscente, meio cilindrica, dura, pouco comprida, de coloração marrom brilhante, internamente revestida por polpa carnosa, farinácea, com odor adocicado característico e comestivel. Mede de $12 \mathrm{~cm}$ a $17 \mathrm{~cm}$ de comprimento a 5 de largura, e contém 2 a 8 sementes em média. As sementes são cor de vinho, ovaladas, com tamanho e formas varáveis, em média com $2 \mathrm{~cm}$ de comprimento.

Quanto ao sistema reprodutivo, há evidências de protoginia e alogamia, sendo que a polinização é feita principalmente por quiropterofilia. Os morcegos são visitantes noturnos e o seu comportamento está adequado ao de um polinizador efetivo; verificase um período de sobreposição entre visitantes diurnos e noturnos, durante o qual os beija-flores podem estar exercendo ação polinizadora (Crestana 1986). 
A dispersão de sementes é barocórica e zoocórica; a semente passa pelo trato digestivo dos animais superando a dormência, e muitas vezes nem chega a ser ingerida, somente deslocada, vindo a germinar sem ter sofrido algum tipo de escarificação.

A espécie pode ser enquadrada dentro do grupo sucessional como espécie secundária tardia /clímax; espécies característica do interior da floresta primária, podendo ocorrer em áreas secundárias com mais alta densidade .

Atualmente, $\mathrm{o}$ aproveitamento das árvores deste gênero tem dois destinos. As espécies de mata, especialmente $H$. courbaril, são conhecidas pela produção de resina, que é extraída do tronco através de "sangria" ou derrubada, ou então escavada no solo, onde às vezes se acumulam quantidades de resina provenientes do tronco e de galhos. Esta resina é conhecida como "Jutaicira", ou copal americano, sendo aproveitada como verniz em marcenaria (Rizzini 1971), além disso goza de fama medicinal no interior do pais, onde, sob o nome de "vinho" ou "licor de jatoba", é prescrita para doenças pulmonares ou como tônico .

A madeira de jatobá possui massa especifica aparente de 0,90 a $1,10 \mathrm{~g} / \mathrm{cm} 3$ (pesada a muito pesada), massa especifica básica de $0,75 \mathrm{~g} / \mathrm{cm} 3$ (madeira pesada), com baixa retratibilidade e alta resistência mecânica. 


\section{MATERIAL E MÉTODOS}

\subsection{Caracterização da área}

A região onde se desenvolveu o presente estudo, denominada "Pontal do Paranapanema", possui a mesma delimitação da antiga "Grande Reserva do Pontal do Paranapanema", criada em 1942 pelo governador do Estado de São Paulo. De acordo com Ferrari-Leite (1998), os limites dessa reserva são constituídos ao norte pelo Ribeirão Anhumas, ao sul pelo Rio Paranapanema, a oeste pelo Rio Paraná e a leste pelo espigão divisor de águas do Paraná-Panema e Ribeirão Cachoeira do Estreito.

Os limites considerados hoje pelo Governo do Estado, ao lidar com questão de regularização fundiária e assentamentos, vão além daqueles da Grande Reserva, estendendo-se ao norte até o Rio do Peixe e a leste até o Rio Laranja Doce e Ribeirão dos Guachos (Ditt, 2000.)

Entre 1941 e 1942, o governador de São Paulo decretou que toda a área a oeste do Pontal passaria a ser uma Reserva de Fauna e Flora (Valladares-Pádua 1987). Nos anos 50, todavia, o então governador Ademar de Barros distribuiu as terras da reserva entre seus amigos e correligionários, que iniciaram um processo voraz de ocupação do solo. Devido a essa ocupação sem critérios, o Pontal do Paranapanema sofreu drástica redução em sua cobertura florestal.

Ainda como conseqüência desse modo de ocupação, houve grande concentração de terras devolutas em poder de poucos fazendeiros - $8 \%$ dos proprietários rurais detêm a posse de $75 \%$ dos 246.840 ha da grande Reserva do Pontal (IPÊ, 2000). 
Mais recentemente, ocorreu um segundo processo de ocupação territorial por parte de grupos de agricultores, organizados nos últimos anos, no Movimento dos Trabalhadores Rurais Sem Terra (MST).

Os números atuais mostram a existência de 4.500 familias assentadas em glebas no Pontal, ocupando um total de 38.000 ha, sendo que cada lote das respectivas glebas tem em média 15 ha. As projeções futuras para a região são de assentar 50.000 famílias em um total de 1 milhão de ha de terras devolutas na região.

Devido ao processo de ocupação, a paisagem do Pontal do Paranapanema foi alterada, formando-se um novo mosaico na região, cuja matriz é constituída predominantemente por pastagens, onde os fragmentos podem ser considerados ilhas de biodiversidade.

A maior parte das áreas florestais que restam (aproximadamente $1,85 \%$ da cobertura original) concentram-se no Parque Estadual do Morro do Diabo (35.000 ha) e em alguns fragmentos localizados em propriedades privadas (Dean 1996), que soman aproximadamente 15.000 ha.

Tabela 1. Número de fragmentos em cada classe de tamanho no Pontal do Paranapanema

\begin{tabular}{ccc}
\hline $\begin{array}{c}\text { Área } \\
\text { (ha) }\end{array}$ & Número de fragmentos & $\%$ de área \\
\hline $5-50$ & 273 & $79,13 \%$ \\
$50-100$ & 32 & $9,28 \%$ \\
$100-150$ & 14 & $4,00 \%$ \\
$150-200$ & 6 & $1,74 \%$ \\
$200-250$ & 5 & $1,45 \%$ \\
$250-300$ & 2 & $0,6 \%$ \\
$300-500$ & 4 & 1,16 \\
$500-600$ & 4 & 1,16 \\
$850-900$ & 1 & $0,3 \%$ \\
$1150-1200$ & 1 & $0,3 \%$ \\
$1300-1350$ & 1 & $0,3 \%$ \\
$1850-1900$ & 1 & $0,3 \%$ \\
$1950-2000$ & 1 & $0,3 \%$ \\
\hline
\end{tabular}

(adaptado de Ditt 2000) 
Para esse estudo considera-se o tamanho do fragmento Sumida como médio e o fragmento Alcidia como grande, classificação baseada em Bawa, (1991).

\subsubsection{Vegetação}

A região denominada Pontal do Paranapanema era originalmente coberta por florestas, entremeadas por pequenas manchas de cerrado, em um mosaico que Veloso et al., (1991) denominam "zona de tensão ecológica", com transição na forma de ecótono ou encrave.

A vegetação da região foi classificada como mesófila semidecidual (Rizzini ,1971) ; floresta estacional semidecidual (Veloso et al., 1991) e mata de planalto (Leitão Filho, 1995).

Para este estudo adotou-se a classificação de Veloso et al. (1991), que além de utilizarem critérios fisionômicos e ecológicos, baseiam-se numa revisão abrangente dos principais trabalhos já realizados de fitogeografia no Brasil. Segundo esses autores, a vegetação do Pontal é denominada floresta estacional semidecidual, caracterizada pela presença de duas estações climáticas: tropical, com intensas chuvas de verão seguidas de estiagens acentuadas; e subtropical, sem periodo seco, mas com seca fisiológica provocada pelo frio do inverno. De 20 a $50 \%$ das árvores são caducifólias. Os mesmos autores afirmam que essa cobertura florística originou-se na flora do escudo Atlântico, refugiada no Pliopleistoceno (Schliter, 1990).

Joly et al. (1999) apresentam argumentos para solidificar o conceito amplo de Mata Atlântica, que incorpora as florestas estacionais dos estados de São Paulo, além de outros 09 estados e de países vizinhos como Paraguai e Argentina.

É dentro deste bioma, que tem sido considerado uma das áreas prioritárias para a conservação no panorama global com base em diversidade biológica e grau de ameaça, que se inserem as áreas deste estudo.

Pelo menos duas paisagens fitogeográficas se distinguem na região: a vegetação dos espigões e a vegetação da várzea (Schliter, 1990). O primeiro conjunto 
apresenta variações no porte e exuberância das espécies existente no topo dos espigões e nos vales presentes entre eles. A comunidade dos vales apresenta-se mais rica e variada, indicando talvez solos de melhor qualidade e com mais umidade.

Cabe ressaltar que em função do processo de ocupação a maior parte dos fragmentos encontra-se nas áreas dos espigões pois, ao ser derrubada a mata, o critério de escolha era a qualidade do solo, tendo o tipo de cobertura como indicador de fertilidade (porte e espécies arbóreas). A exceção são os maiores fragmentos, nos quais é possivel ainda encontrar várias fisionomias relacionadas à fertilidade dos solos e à topografia.

\subsubsection{Relevo, solos e clima}

O Pontal do Paranapanema insere-se na província geomorfológica conhecida como Planalto Ocidental de São Paulo. Colinas amplas são as formas de relevo locais, com baixas declividades (menos de $15 \%$ ) e interflúvios com mais de $4 \mathrm{Km}^{2}$.

Seu solo é originário de rochas do grupo Bauru, sendo latossolo o tipo predominante na região. Além da elevada concentração de areias, destacam-se como principais características a baixa fertilidade natural, boa permeabilidade e drenagem excessiva.

De acordo com os mapas produzidos em 1998 pela Secretaria do Meio Ambiente do Estado de São Paulo, para o "Zoneamento Ecológico Econômico do Estado de São Paulo", a fragilidade natural do solo à erosão é considerada média ou alta em toda a região.

A aptidão agrícola das terras do pontal, de acordo com esses mapas, é regular para lavouras com cultivo de baixa tecnologia e restrita para médias e altas tecnologias empregadas.

A alternância de periodo seco e frio (de maio a agosto, com média de $17 \mathrm{C} \mathrm{em}$ junho) e período quente e úmido (de novembro a fevereiro, com média de $25 \mathrm{C}$ ), 
caracteriza o clima do pontal, com concentração de chuvas de dezembro a janeiro e precipiłação anual média de $1300 \mathrm{~mm}$.

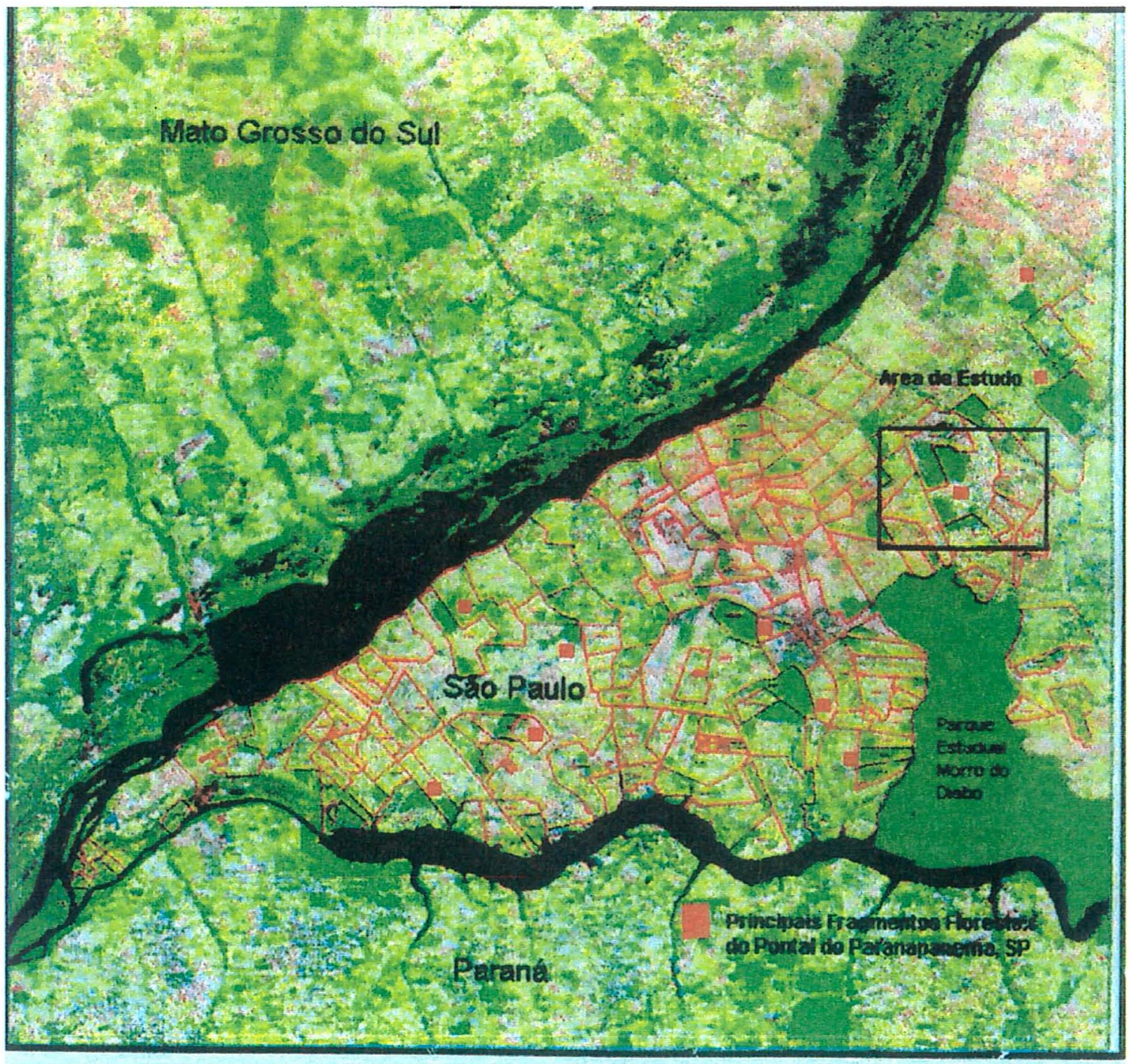

Figira 1- Imagem de satélite da região do Pontal do Paranapanema. Linhas vermelhas delimitam áreas cadastradas pelo INCRA. Quadrado delimita área deste estudo. 


\subsection{Descrição dos locais de estudo}

\subsubsection{O Parque Estadual do Morro do Diabo}

O Parque Estadual do Morro do Diabo (PEMD), possui uma área de aproximadamente 35.000 ha.

$\mathrm{Na}$ década de 40 foram abertas algumas clareiras no interior da mata por posseiros, que mais tarde foram retirados. Três estradas de rodagem, duas municipais e uma estadual (a SP -563, asfaltada) cortam as áreas do parque no sentido lesteoeste. Na década de 60 construiu-se o ramal ferroviário de Dourados, pertencente à FEPASA, que cortou toda a extensão leste-oeste do parque, sendo que hoje encontrase desativado.

Em 1986 a Companhia Energética de São Paulo (CESP), desmatou aproximadamente $8 \%$ da área, devido ao represamento do Rio Paranapanema, quando da construção da Hidrelétrica de Rosana. Em algumas áreas a mata foi totalmente derrubada, dando lugar a clareiras invadidas por gramineas, algumas introduzidas pelos posseiros. Em outros locais, o corte seletivo, à procura de madeiras nobres, foi tão intenso que descaracterizou a vegetação como tipo florestal.

Existem, porém, grandes áreas ainda preservadas e que podem ser consideradas como representativas da floresta outrora existente em toda a região do Pontal.

A altitude média é da ordem de $320 \mathrm{~m}$, com relevo suave ondulado ou plano, com exceção do "Morro do Diabo", cuja altitude alcança $570 \mathrm{~m}$.

Os solos ocorrentes no parque são em sua maior parte da formação Caiuá, do tipo Lea ou Latossolo vermelho-Escuro, fase arenosa (Schliliter, 1990).

\subsubsection{Os fragmentos florestais do Assentamento Rural Água Sumida.}

Em 1990 cerca de 120 famílias foram assentadas entre e no entorno de dois dos fragmentos florestais mais significativos da região do Pontal. 
O Assentamento Rural Água Sumida no Pontal do Paranapanema é um bom exemplo da dinâmica da ocupação das terras na região. Cada família possui um lote de 15 ha sendo que um terço é normalmente usada para agricultura de subsistência (milho, algodão, mandioca, arroz, feijão e outros) e o restante para uma pecuária leiteira de pequena escala.

Os fragmentos contidos nos limites do Assentamento Água Sumida, utilizados para este estudo juntamente com a área do PEMD, serão denominados de "Sumida" e "Alcídia".

Observações de campo (Ditt, 2000) indicaram que o fragmento ao norte do Assentamento Água Sumida, o "Alcídia", com seus 1.150 ha, ainda abriga populações viáveis de algumas espécies vegetais consideradas raras na região. Por outro lado, nos 553 ha do fragmento localizado ao sul do assentamento ("Sumida"), as mesmas observações indicaram a presença de populações isoladas e bastante reduzidas.

O "Sumida" tem toda sua área delimitada dentro do Assentamento, fazendo parte da área de reserva legal. Possui um histórico de perturbação bastante intenso; suas bordas são constantemente afetadas pela entrada de fogo (a última ocorrência foi em janeiro de 2000), e há pelo menos 06 anos algumas áreas do seu interior foram queimadas. Não existe datação precisa do início das retiradas de madeira da área, mas é possivel afirmar a ocorrência dessas retiradas, em função dos diferentes estádios de regeneração na área e resíduos (tocos) em diferentes estágios de degradação - o que denota cortes em épocas diferentes. Aparentemente nenhum corte aconteceu há menos de 5 anos.

$\mathrm{Na}$ área ocorrem relativamente poucas espécies da fauna local (IPÊ, 1999), destacando-se os grandes ongulados e os pássaros (residentes e em deslocamento), onde principalmente os mamíferos podem ser relevantes para a dinâmica da espécie selecionada para este estudo (o jatobá), por se tratarem, em alguns casos, de importantes dispersores e predadores de sementes e plântulas. A ocorrência dessas espécies pode ser atribuida à proximidade desse fragmento com os 35.000 ha do PEMD, que dista 2.900 metros (distância entre as bordas mais externas em linha reta, calculado através de projeção com base em foto aérea) 
O fragmento "Alcídia" é considerado um dos mais importantes fragmentos florestais do Pontal do Paranapanema (Ditt, 2000), tanto por suas dimensões quanto por seu relativo bom estado de conservação e posição estratégica que ocupa na paisagem. Dista 5320 metros do PEMD(distância entre as bordas mais externas em linha reta, calculado através de projeção com base em foto aérea)

Aproximadamente metade da área do fragmento Alcídia faz parte da Fazenda Alcídia do Bolet, de propriedade da Usina Alcídia, de cana-de-açúcar. A outra metade consiste em área de reserva legal do assentamento "Água Sumida", do INCRA. Os relatos dos antigos e atuais proprietários registram o processo de derrubada da mata nos últimos 40 anos (Ditt, 200) - que resultou na forma e tamanho do fragmento atual. O último registro de fogo na área é de 10 anos, tendo atingido apenas uma pequena área de borda.

O fragmento possui duas estradas (inativas) construídas há aproximadamente 25 anos, cortando a área longitudinalmente, que serviam de passagem tanto para o gado quanto para o trânsito de pessoas entre fazendas vizinhas. Atualmente são vias de acesso para a extração ilegal, onde são extraídas diversas espécies de valor econômico (jatobá, cedro, peroba, ipês, sobrasil, canafístula, etc.), preferencialmente com diâmetros reduzidos em função do desdobramento das toras ser feito dentro da mata e do transporte ser realizado em pequena quantidade e de forma escalonada, por se tratar de atividade ilegal.

Da mesma forma que o "Sumida", o "Alcidia" ainda propicia a existência de uma fauna representativa do ecossistema local (IPÉ, 1999).

De maneira geral as duas áreas encontram-se sob intensa pressão antrópica, o que pode ser considerado como situação generalizada entre os fragmentos da região, com exceção de algumas poucas áreas localizadas em propriedades particulares e que hoje são relativamente bem protegidas. 


\subsection{Seleção das áreas}

A escolha dos fragmentos para o presente estudo seguiu os seguintes critérios:

- possuírem "população" da espécie alvo do estudo - Hymenaea courbaril L.

- estarem inseridos numa porção da paisagem que represente a maior parte da configuração atual do Pontal ( padrão de uso e cobertura do solo);

- possuírem dados sobre sua diversidade biológica e histórico de perturbação;

- haver facilidade de contato e comunicação entre as comunidades do entorno;

A escolha dos fragmentos florestais baseou-se ainda na localização das subpopulações da espécie escolhida. Foram estudadas três populações, uma distribuída em fragmento florestal cujas falhas permitem a movimentação dos vetores da reprodução da espécie a ser estudada ("floresta contínua" - PEMD); e outra distribuída em fragmentos florestais separados por barreiras para a movimentação dos vetores de reprodução (fragmentos isolados - "Sumida e Alcídia"). 


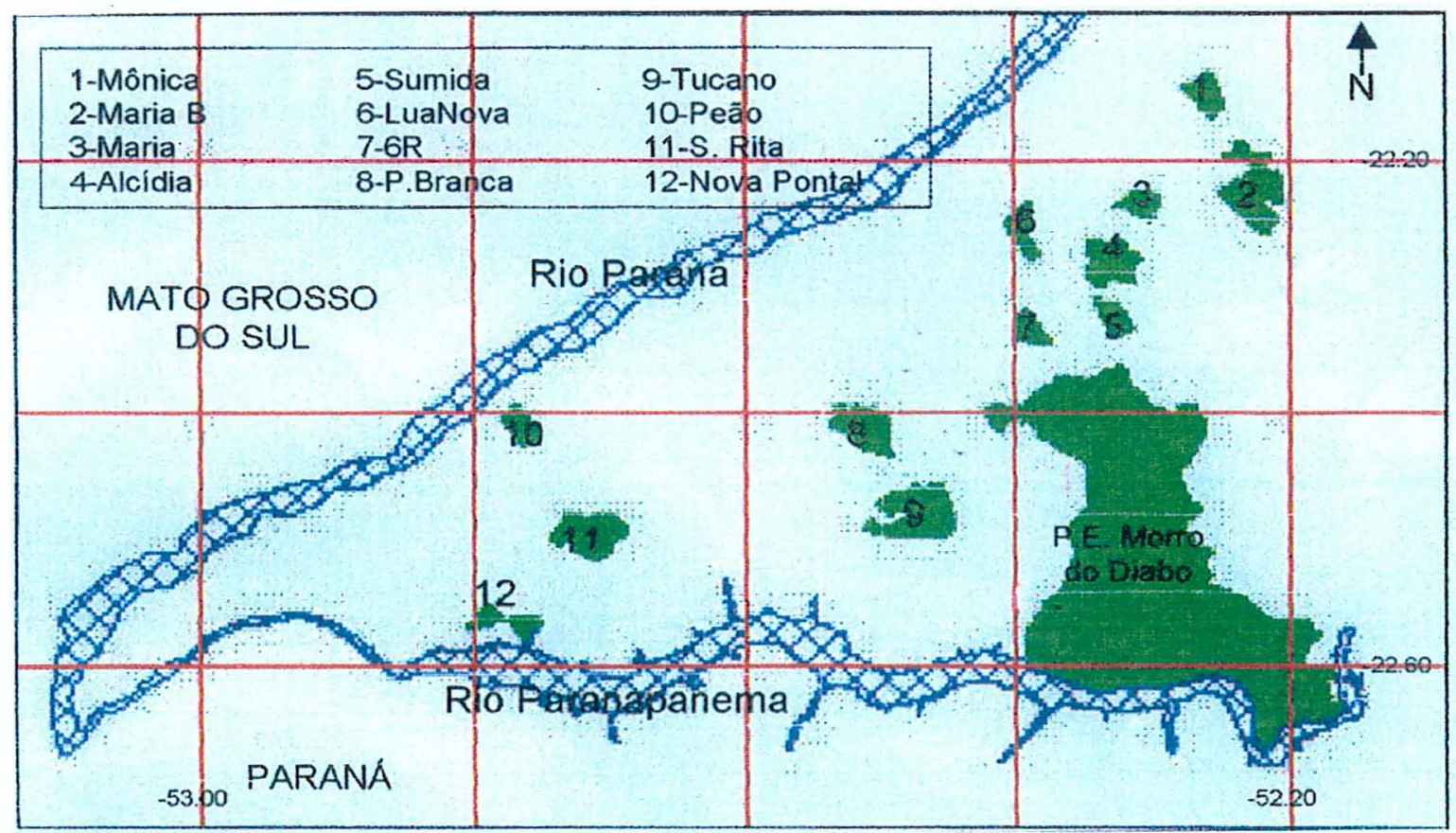

(Fonte, Ditt ,2000)

Figura 2- Esquematização dos principais fragmentos florestais do Pontal do Paranapanapanema com área superior à 300 ha. 


\subsection{Seleção da espécie}

Para um ecossistema com altíssimo número de espécies, como a floresta tropical, a escolha das espécies para estudo passa a ter cada vez mais importância, principalmente se quisermos extrapolar os resultados para espécies com características semelhantes, fundamentados no conceito de espécies-modelo apresentado por Terborgh (1986).

De acordo com Hamrick et al. (1986), caracteristicas de história vital e o tipo de estrutura demográfica podem determinar diversos padrões de estrutura genética. Supondo que esta hipótese seja confirmada, seria possível utilizar espécies modelo que caracterizam grupos de espécies com características ecológico-demográficas semelhantes para predizer a estrutura genética das demais espécies deste grupo, e os possiveis efeitos da fragmentação sobre estas estruturas, conforme sugerido por Kageyama e Gandara (1994).

A escolha da espécie alvo obedeceu os seguintes critérios:

- estar presente nas áreas de estudo, no parque e nos dois fragmentos;

- possuir baixa densidade natural ;

- possuir informações ecológicas;

- possuir protocolos genéticos prontos ou possíveis de serem desenvolvidos;

- ter o movimento de seus vetores de reprodução possivelmente incapacitados por barreiras que quebram a continuidade da paisagem florestal na região (por exemplo agricultura, estradas, pastagens)

O jatobá (Hymenaea courbaril L.) é uma espécie de elevado valor comercial, com distribuição geográfica abrangendo quase toda a América Latina, e com baixa densidade natural em florestas primárias. Está presente em todas as áreas de estudo (conforme levantamentos fitossociológicos realizados nos Fragmentos por Durigan et al 
(submetido) e no PEMD por Schlitter (1990) e Baitello at al. (1988). Os mesmos trabalhos demonstram que a espécie ocorre em relativa baixa densidade natural nas três áreas.

Desta forma, Hymenaea courbaril L. foi utilizada como uma espécie modelo que poderá representar espécies de final de sucessão e de baixa densidade, de polinização a longa distância e dispersão de sementes por animais.

\subsection{Levantamento das populações, Coleta de Materiais a produção de Mudas (Progênies)}

Para este estudo foram amostradas três populações de Hymenaea courbaril localizadas: no Parque Estadual do Morro do Diabo, no Fragmento Alcídia e no Fragmento Sumida.

A localização dos indivíduos da espécie dentro das áreas de coleta se deu por caminhamento sistemático, onde foram feitos transectos lineares em média com 1000 metros cada um, distantes entre si 50 metros, onde todos os indivíduos da espécie com diâmetro acima de $40 \mathrm{~cm}$ de DAP foram amostrados. Foram considerados indivíduos adultos, árvores com DAP mínimo de $40 \mathrm{~cm}$.

As áreas de coleta dentro do PEMD e no Fragmento Alcídia foram delimitadas pela ocorrência dos indivíduos adultos, sendo que o limite de cada uma foi determinado pela distribuição espacial dos indivíduos arbóreos. Para localização do primeiro individuo em cada área, foram escolhidos locais dentro de cada área que representassem a estrutura mais bem conservada de cada uma. No PEMD procurouse amostrar uma área onde não tivesse havido exploração madereira ou descaracterização da fisionomia por outro tipo de intervenção antrópica.

A princípio, foram programadas coletadas de folhas de 30 indivíduos em cada uma das três áreas (nos dois Fragmentos e no PEMD), totalizando 90 indivíduos adultos. 
No menor dos fragmentos (Sumida) não foram encontrados os 30 indivíduos;assim, apenas 23 árvores compõem a população de individuos adultos e reprodutivos. Nas outras duas áreas foram mapeados os 30 indivíduos.

As árvores foram mapeadas com 0 auxílio de trena e bússola, e georeferenciados com GPS. Estes individuos estão distribuídos de forma contínua no espaço, evitou-se deixar indivíduos não coletados entre individuos coletados. Esta precaução é importante para que se possa estimar com maior precisão o fluxo gênico e a paternidade. A exceção foi a população do Sumida, onde, devido à mesma ser restrita, todos os indivíduos encontrados no censo foram coletados, não levando-se em conta a continuidade o que compreendeu toda a área do fragmento.

As folhas coletadas de cada individuo foram desidratadas em frascos adequados contendo sílica gel, e transportadas para o Laboratório de Reprodução e Genética de Espécies Arbóreas (LARGEA), do Departamento de Ciências Florestais da ESALQ/USP em Piracicaba - SP, onde foram feitas as análises laboratoriais.

Foram coletados frutos somente das 23 matrizes da população Sumida para a execução das análises de progênies. As sementes coletadas das matrizes foram colocadas para germinar, após a quebra de dormência, no Laboratório de Sementes do Departamento de Ciências Florestais (ESALQ/USP). As plântulas assim obtidas foram repicadas para obtenção das mudas, das quais foram coletadas folhas para a extração de DNA. Cada família foi constituída por 11 indivíduos, sendo um indivíduo adulto e 10 progênies, para tanto os indivíduos foram classificados conforme área de ocorrência, onde fora denominada o número da matriz(progenitor materno) a área de onde fora amostrada (PEMD -1, Alcídia - 2 e Sumida - 3) da mesmas forma classificados as sementes que deram origem às progênies. 


\subsection{Análises ecológicas}

Foram mapeadas as árvores existentes nos fragmentos "Sumida" e "Alcídia" e na área do PEMD, para acompanhamento e coleta de material para análise genética, assim como para identificação e acompanhamento dos indivíduos.

Vários foram os aspectos observados para que se pudesse inferir sobre possiveis conseqüências da frạgmentação, sendo eles:

acompanhamento da fenologia do jatobá nos três locais de estudo, onde foram acompanhados sistematicamente a floração e frutificação de todos os 83 indivíduos adultos objeto deste estudo, no periodo de outubro de 1998 a janeiro de 2001.

- presença dos possiveis dispersores das sementes da espécie por meio de observações diretas e indiretas, assim como pelo acompanhamento de relatos de outros pesquisadores;

- Registro sistemático dos eventos ocorridos nas áreas (fogo, geada, etc.);durante o período do estudo , assim como levantamento dos históricos de eventos passados.

- Avaliação das características da paisagem, a fim de investigar as diferenças que existem entre os fragmentos, quanto às suas áreas e às distâncias dos fragmentos que se localizam no seu entorno, e quanto às suas distâncias em relação ao PEMD . 


\subsubsection{Fenologia da espécie}

Para este estudo foram feitas observações quinzenais, nas épocas de pico de floração e mensais após a queda das flores, para acompanhar a frutificação das árvores.

O acompanhamento foi efetuado em todos os indivíduos do Fragmento Sumida num total de vinte e três (23), em trinta (30) árvores no "Alcídia" e em trinta (30) individuos no PEMD.

Em função da relativa baixa densidade de indivíduos, os estudos fenológicos feitos com a espécie estão baseados em poucos indivíduos (30 - PEMD, 30 - Alcídia e 23 no Sumida), sendo que os objetivos principais do acompanhamento foram: obter sementes (progênies) para análise do sistema reprodutivo da espécie; descrever a fenologia reprodutiva da espécie nas áreas de estudo e sua possível relação com os efeitos da fragmentação.

\subsubsection{Ecologia da paisagem}

A análise da paisagem do Pontal do Paranapanema foi feita visando investigar as diferenças que existem entre os fragmentos florestais da região, quanto às possiveis dificuldades enfrentadas pelos organismos que neles habitam, para se movimentar em direção dos fragmentos vizinhos.

No início desse estudo, os mapas em escala 1:50.000, com data de 1988, pertencentes ao Instituto Florestal, que foram utilizados na confecção do Inventário Florestal do Estado de São Paulo (Kronka et al.,1993), eram os mais recentes e em melhor escala a respeito da cobertura florestal da região do Pontal. Os contornos dos fragmentos florestais contidos nestes mapas foram digitalizados através do software Camris, possibilitando um cálculo aproximado e preliminar de suas áreas. 


\section{- Avaliação da conectividade estrutural}

A conectividade caracteriza a capacidade da paisagem facilitar ou impedir movimentos entre as manchas (Taylor et al., 1993).

Na avaliação da conectividade estrutural, Metzger e Décamps (1997) sugerem que sejam consideradas a continuidade no arranjo espacial das manchas florestais, a complexidade e a qualidade da rede de corredores e de pontos de ligação e a permeabilidade da matriz. A quantificação desses componentes pode ser feita medindo-se: a percolação ; as distâncias e densidades dos diversos tipos de corredores e de pontos de ligação; e as distâncias funcionais ente os fragmentos.

Dois parâmetros foram adotados nessa pesquisa para quantificar a conectividade das áreas do entorno de cada um dos dois fragmentos objeto deste estudo em relação a área do PEMD. O primeiro deles refere-se à percolação. Para avaliar a percolação, utilizou-se a metodologia sugerida por Ditt (2000), onde desenharam-se no mapa de cobertura florestal treze quadrados de $16 \mathrm{Km}$ de lado, cada um contendo no seu interior uma das grandes manchas florestais estudadas. Em cada quadrado os limites de todos os fragmentos florestais presentes sofreram dilatações sucessivas, transferindo-se para os pixels adjacentes que faziam parte da matriz. Foi determinado, em cada quadrado, o número de dilatações dos fragmentos necessário para que houvesse percolação.

O segundo parâmetro de conectividade avaliado refere-se à influência das distâncias entre as manchas sobre a movimentação dos organismos pela paisagem. No modelo assumi-se arbitrariamente que determinados organismos conseguem atravessar uma distância máxima pela matriz, para este estudo adotou-se uma distância de mil metros $(1 \mathrm{Km})$ no espaço entre as manchas, calculou-se a máxima distância possivel de ser percorrida. Posteriormente foram comparados os dados obtidos com as mesmas métricas para outros 11 fragmentos na mesma paisagem efetuados em outros estudos. 


\subsection{Análises genéticas}

\subsubsection{Análise de Marcadores Microssatélites}

Entre as classes de marcadores moleculares existentes, os marcadores baseados em Seqüências Simples Repetitivas (SSR) ou microssatélites são, certamente, os que mais se aproximam do marcador ideal para estudos de estrutura $e$ dinâmica de populações assim como do fluxo gênico.

Os pares de "primers" utilizados para a amplificação de regiões de microssatélites dinucleotídeos (AG/CT) em $H$. courbaril foram desenvolvidos e caraterizados por cinco locos foram utilizados na determinação de todos os parâmetros genéticos. O coquetel $(13 \mu l)$ para a realização da reação da polimerase em cadeia (PCR) foi composto por : Tp 10x (com Mgcl2), dntp (2,5mM), BSA(2,5 mg/ml), Mgcl2 (25 mM), Primer e Taq-polimerase.

As amplificações foram realizadas em termociclador através do seguinte protocolo: $96^{\circ} \mathrm{C}$ por 2 minutos; 30 ciclos de $94^{\circ} \mathrm{C}$ por 1 minuto, temperatura de anelamento $\left(58 \mathrm{C}\right.$ ) para todos os primers por 1 minuto $72^{\circ} \mathrm{C}$ por 1 minuto e terminando com $72^{\circ} \mathrm{C}$ por 7 minutos.

O desenvolvimento dos marcadores SSR foi realizado no Laboratório de Genética de Plantas do Centro Nacional de Recursos Genéticos e Biotecnologia (CENARGEN/EMBRAPA). 


\subsubsection{Análises Estatísticas}

\subsubsection{Diversidade Genética Intrapopulacional}

A variabilidade genética dentro das populações foi caracterizada através das freqüências alélicas de cada população e através dos índices de diversidade.

Os índices de diversidade estimados foram: heterozigosidade média observada, heterozigosidade média esperada $\left(\hat{H}_{e}\right)$ segundo expectativas do equilíbrio de HardyWeinberg, número médio de alelos por loco $(\hat{A})$, porcentagem de locos polimórficos $(\hat{P})$ e índice de fixação de Wright $(\hat{f})$. As estimativas foram obtidas utilizando-se o programa GDA (Lewis \& Zaykin, 2002).

\subsubsection{Diversidade Genética Interpopulacional}

A estrutura genética das populações foi abordada por análise de variância das freqüências alélicas (Cockerham, 1969; Vencovsky, 1994) e estatística $F$ de Wright (Wright, 1965). A análise de variância fornece a distribuição da variabilidade genética nos vários niveis hierárquicos em que está estruturada a amostragem; os niveis de fixação alélica dentro e total das populações; o tamanho efetivo populacional $\left(\hat{N}_{e}\right)$; e ainda informa sobre as melhores estratégias de amostragem.

Para o cálculo do Tamanho Efetivo Populacional $\left(N_{e}^{\prime}\right.$ de cada população considerada isoladamente, utilizou-se a expressão apresentada por Vencovsky, (1994):

$\left.N_{\mathrm{e}}=\mathrm{N} /(1+f)\right)$

Sendo:

$\mathrm{N}=$ número de indivíduos adultos

$f=$ coeficiente de endogamia intrapulacional. 


\subsubsection{Sistema Reprodutivo ou taxa de cruzamento}

A taxa de cruzamento foi caracterizada usando-se as progênies de uma das populações, a partir da taxa de cruzamento unilocos $\left(\hat{t}_{s}\right)$ e multilocos $\left(\hat{t}_{m}\right)$, estimadas por meio de estimativas de máxima verossimilhança ( Ritland e El-Kassaby, 1985).

Estas taxas de cruzamentos foram obtidas para a população - Sumida , utilizando-se o programa MLTR ("Multilocos R") de Ritland (1990), para marcadores codominantes. $O$ programa estima $\hat{t}_{s}, \hat{t}_{m}$ e $\hat{t}_{m}-\hat{t}_{s}$, sendo que este último corresponde à proporção de acasalamentos entre individuos aparentados. A correlação entre as taxa de cruzamento dentro das progênies $\left(r_{t}\right)$ e a correlação entre parentais de individuos resultantes de cruzamento dentro das progênies $\left(r_{p}\right)$ que é a probabilidade de um par de indivíduos de uma progênie se constituído de irmãos germanos. Os desvios padrão das estimativas foram determinados por 10.000 reamostragens (bootstraps) entre indivíduos)

Para estimar o erro padrão das estimativas de cruzamento unilocos e multilocos para a população, o programa utiliza o método de reamostragem, onde as unidades de amostragem são as plantas dentro das familias. Foram utilizadas 100 reamostragens dentro das famílias.

\subsubsection{Análise de Paternidade (fluxo gênico interno)}

A determinação de paternidade das sementes produzidas por polinização aberta será feita através de exclusão de paternidade pelo cálculo do índice de paternidade, Probabilidade de Paternidade e Probabilidade de Exclusão (Ellstrand, 1998; Stacy et al.,1996). Com a análise de genótipos multilocos de 5 microssatélites das árvores parentais e das progênies de polinização aberta, espera-se atingir uma probabilidade de paternidade média de $99 \%$. Os dados sobre as distâncias dos fluxos de pólen serão relacionados à distribuição espacial das árvores. 


\subsubsection{Teste de Paternidade}

Os testes de paternidade foram realizados através do método de exclusão, descrito por Weir (1996) e aperfeiçoado por (Gaiotto et al., 2001 a). A análise de exclusão de paternidade foi realizada através da comparação dos genótipos de todos os indivíduos contra cada uma das progênies analisadas. $\mathrm{O}$ indice de paternidade ( $\mathrm{PI})$ foi estimado para cada loco e o índice de paternidade combinado (CPI) entre os locos em desequilíbrio de ligação (Gaiotto et al., 2001)' foi utilizada para inferrir a probabilidade de paternidade (PP).

Foram utilizadas três diferentes probabilidades a priori $(P)$ para as estimativas de (PP): i) 0,5 que é prioridade a priori (Gaiotto, et al 2001). As razões de verossimilhança para cálculos de paternidade foram obtidas a partir das frequência alélicas estimadas para a base de dados compostas pelos 83 indivíduos adultos amostrados, utilizando uma freqüência mínima de alelos de $5 / 2 n$, ou seja, 0,030 ( Modelo de estimação propostos por Gaiotto et al, 2001). 


\section{RESULTADOS E DISCUSSÃO}

\subsection{Aspectos ecológicos e da paisagem}

\subsubsection{Estrutura da paisagem}

$\mathrm{Na}$ tabela 02, apresentam-se os resultados numéricos das avaliações de parâmetros da paisagem: distância dos fragmentos ao parque, área dos fragmentos, percolação e conectividade.

Tabela 2. Valores obtidos para os fragmentos florestais na avaliação de parâmetros da paisagem. DPEMD = distância dos fragmentos ao Parque Estadual do Morro do Diabo.

\begin{tabular}{ccccc}
\hline Fragmento & $\begin{array}{c}\text { DPEMD } \\
(\mathrm{km})\end{array}$ & $\begin{array}{c}\text { Área } \\
(\mathrm{ha})\end{array}$ & Percolação & Conectividade \\
\hline Alcidia & 7.4 & 1175 & 18 & 5200 \\
Sumida & 3.5 & 553 & 15 & 5212 \\
\hline
\end{tabular}

Com relação à distâncias entre os fragmentos estudados, os mesmo encontram-se relativamente perto do PEMD, comparados aos demais fragmentos existentes na paisagem, onde existem áreas que distam até $39 \mathrm{~km}$ do PEMD,

A amplitude de área entre os fragmentos de mata na região é muito grande; o menor fragmento tem aproximadamente 5 hectares e o maior 2000 hectares. Sendo assim, as áreas dos fragmentos objeto deste estudo não podem ser consideradas como representativas da paisagem como um todo, mas servem como parâmetro a respeito da sustentabilidade dessas áreas e das demais, com relação à capacidade de conterem populações viáveis de espécies arbóreas raras. 
Os índices de percolação podem ser considerados bons, se comparados aos mesmos obtidos por Ditt (2000), que encontrou para percolação um índice de 20 para o Fragmento Alcídia e 17 (amplitude de 17 a 44) para o Fragmento Sumida, que representa o número de dilatações necessárias para que haja continuidade espacial unindo dois lados extremos dos polígonos de dilatação. Para o parâmetro conectividade os resultados foram considerados baixos, 5357 para Alcídia e 5948 para Sumida (amplitude de 4534 a 39806).

Isso quer dizer que o fragmento Sumida apresenta uma condição um pouco masi mais favorável da matriz com relação à movimentação de organismos, apesar de possuir uma área menor que o Alcidia e estar mais degradado. As diferenças entre os índices encontrados nesse trabalho, com relação aos dados obtidos por Ditt (2000), devem estar relacionadas aos arredondamentos referentes à amplitude de amostragem, tendo em vista que o autor citado calculou os mesmos índices para 13 fragmentos e para este estudo foram calculados os índices apenas para 02 fragmentos.

As características da paisagem podem ser consideradas favoráveis ao desenvolvimento e manutenção das florestas dos fragmentos Alcídia e Sumida, ao se comparar os dados com outros fragmentos na mesma paisagem em Ditt (2000). Os valores obtidos indicam que as configurações na paisagem são favoráveis à movimentação dos organismos no entorno desses fragmentos e a chegada de propágulos e de pólen. Apesar do índice de conectividade ter sido considerado baixo.

Cabe ressaltar que esses resultados não expressam a situação da região como um todo, tendo em vista que os fragmentos estudados representam um porção muito pequena do número de fragmentos existentes na paisagem.

Por outro lado, o aprofundamento do conhecimento sobre essas áreas remanescentes, assim como sobre suas interações com os demais componentes da paisagem, pode ser indicativo de como se deveria conduzir o manejo e restauração dessa paisagem fragmentada, levando-se em conta que as mesmas podem abrigar populações representativas de Hymenaea courbaril L. e de diversas outras espécies raras. 
Reis (1996), mencionando diversos autores, afirma que o tamanho efetivo populacional tem sido uma abordagem empregada para estimar o número mínimo de indivíduos requeridos para a sustentação de uma população (população mínima viável). Contudo, o mesmo autor, que chama atenção para as variações obtidas nas estimativas, enfatizando a dependência desses valores a aspectos demográficos das populações; o que está relacionado numa conjuntura de paisagens fragmentada ao arranjo espacial dos fragmentos, assim como a área dos mesmo e o estado de conservação.

O grau de isolamento de um fragmento pode afetar o fluxo de animais, pólen e sementes e, portanto, a diversidade biológica e a dinâmica das populações de plantas e animais. É um fator importante na determinação do tamanho efetivo de um fragmento. Fragmentos separados por pequenas distâncias e/ou por vegetação permeável ao fluxo de animais, pólen e sementes, tem o seu tamanho efetivo aumentado.

Portanto, no caso específico dos dois fragmentos objeto deste estudo, as distância entre os mesmos e o PEMD, e entre os demais fragmentos da paisagem, podem estar influindo na polinização e na dispersão de sementes do jatobá, e de outras espécies, sejam essas zoocóricas ou não.

A maior parte dos trabalhos referentes ao deslocamento de organismos em áreas antropizadas se referem à estudos com animais, por exemplo. (Estrada et al.,1993).

A conectividade estrutural pode ser utilizada para inferir sobre a conectividade funcional (Metzger, 1997). Assim, as medidas dos parâmetros genéticos das populações amostradas neste trabalho podem ser considerados como parâmetro de funcionalidade e sobrepostos aos dados de conectividade estrutural, onde pode-se inferir a respeito do sucesso do polinizador em transitar pela matriz, o que pode subsidiar tomadas de decisão quanto ao manejo dessas áreas.

Apesar dos crescentes usos que vem-se fazendo das análises espaciais, não se possui hoje um consenso a respeito de uma análise que possa abranger os diversos 
parâmetros da paisagem em conjunto. Ditt (2000), refere-se aos aspectos das dificuldades das análises tendo em vista que os parâmetros são quantificados separadamente, não havendo uma medida que abranja todos os aspectos da fragmentação.

O tamanho dos fragmentos estudados pode ser considerado grande, se for considera apenas as áreas dos mesmos, se forem comparados à amplitude de áreas dos demais fragmentos existentes na paisagem do Pontal do Paranapanema. Ao considerar as áreas dos mesmos com ralação à capacidade de conter populações viáveis de espécies arbóreas raras, os fragmentos estudados podem ser classificados como médio (Sumida) e grande (Alcídia), considerando como fragmentos pequenos as áreas que estão na faixa das dezenas de hectares ( 1 a $100 \mathrm{ha}$ ), como médios os fragmentos com áreas entre centenas de hectares ( 100 a $1000 \mathrm{ha}$ ) e fragmentos grandes os com mais de um mil hectares ( $>1000$ ha ), conforme sugerido por Bawa, (1991).

\subsubsection{Levantamento do jatobá e distribuição espacial das populações}

$\mathrm{Na}$ análise da distribuição espacial foram amostradas três populações, sendo uma em cada área de estudo. A área amostrada no fragmento Sumida compreende 553 hectares. Considerando que foi realizado um censo em toda a área do fragmento, a localização aproximada das árvores pode ser visualizada na figura 03 .

O método de caminhamento utilizado para o levantamento da população no Sumida parece ter sido eficiente, levando-se em conta que todas as árvores amostradas possuiam mais de 15 metros de altura e quase que na totalidade são emergentes, facilitando sua localização. Foram localizadas árvores em quase toda a área do fragmento, cujo DAP variou entre 60 e $157 \mathrm{~cm}$.

A população do fragmento Sumida, é muito pequena proporcionalmente à densidade encontrada por Durigan et al (submetido), através de método combinado de quadrantes e parcelas, na mesma área. Foram encontrados por meio de censo apenas 23 individuos adultos em idade reprodutiva (considerando-se adultos os indivíduos com 
mais de $40 \mathrm{~cm}$ de DAP); o que eqüivale a 01 indivíduo a cada 24 hectares. Os dados encontrados por Durigan et al apontam 02 individuos/ha. Todas as 23 árvores foram usadas nas análises estatístico-genéticas.

A maior distância entre as árvores amostradas foi de $3,7 \mathrm{~km}$. A distribuição das árvores e a localização da população amostrada podem ser visualizadas na figura 03 . Observa-se no fragmento um grande número de indivíduos jovens, em diferentes classes de tamanho e distribuição diamétrica, principalmente nas bordas e nas grandes clareias existentes no interior do fragmento. Durante o periodo de coleta de dados não foi registrado nenhum evento reprodutivo entre esses indivíduos, que no caso desse estudo são considerados regenerantes pós fragmentação. Cabe ressaltar que espécie aparentemente tem aumentado seu sucesso, no que refere ao recrutamento de novos indivíduos, principalmente em áreas secundárias onde observa-se um grande número de regenerantes, que para este estudo não são considerados reprodutivos.

No fragmento Alcídia foram amostrados 30 indivíduos, sendo que os diâmetros das árvores amostradas variaram entre 41 e $196 \mathrm{~cm}$. A maior distância entre as árvores amostradas foi de $2.6 \mathrm{Km}$. Todas as demais estão contidas num perimetro que totaliza uma área de aproximadamente 90 hectares, o que eqüivale a uma densidade de aproximadamente 1 árvore a cada 3 ha. A distribuição das árvores e a localização da população amostrada podem ser visualizadas na figura 04 .

$\mathrm{Na}$ área amostrada do PEMD foram localizadas 30 matrizes, cujo DAP variou entre 50 e $194 \mathrm{~cm}$, sendo que as 30 árvores foram usadas para as análises estatísticogenéticas. A distância máxima entre as árvores da população amostrada no Parque foi de $2,9 \mathrm{Km}$. As demais estão circunscritas num perímetro aproximado que totaliza 111 hectares, o que permite determinar a densidade no parque em 1 árvore a cada 3,7 ha.

O conjunto de indivíduos amostrado localiza-se numa área do parque onde supõe-se não ter havido impacto antrópico na estrutura da população, baseado tanto na fisionomia da área como pêlos relatos e registros históricos e oficiais da região. Aparentemente a distribuição espacial das árvores sugere uma tendência de agregação, figura 05. Observou-se que a espécie aparentemente apresenta um padrão de distribuição onde existe uma "aglutinação" em média de três indivíduos distantes 
entre si 60 metros, e uma distância média entre esses "agrupamentos" de 500 metros. Essa parece ser uma tendência.

Levando-se em conta as distâncias médias das árvores amostradas na área do fragmento Alcídia e do PEMD, aparentemente a população do fragmento Sumida representa apenas uma porção dos indivíduos que existia na área anteriormente ao processo de fragmentação, onde os 23 indivíduos presentes no fragmento Sumida estão numa área de 553 hectares. Tendo em vista os 90 ha para 30 indivíduos, no Alcídia e 111 ha para 30 indivíduos no PEMD, os dados sugerem que muitos indivíduos ou já foram extraídos por meio de corte ou já morreram. A alta heterogeneidade ambiental da região também pode ser a causa da discrepância entre os dados.

O padrão de distribuição espacial pode vir a influir na dinâmica das populações analisadas. A distância entre as árvores no fragmento Sumida, em muitos casos eqüivale à distância máxima de alguns "agrupamento" de árvores de jatobá amostradas no fragmento Alcidia. O mesmo se aplica às árvores amostradas no PEMD. Além desses aspectos, a localização das árvores nas bordas, em clareiras ou no interior da mata pode influir na dinâmica de polinização e dispersão e variar conforme o tamanho das áreas.

A análise dos dados de autocorrelação espacial possibilitará que se verifique se os genótipos apresentam distribuição aleatória ou estruturada, ou seja, neste último caso se as árvores que estão próximas podem ser mais semelhantes ou completamente diferentes geneticamente umas das outras.

O jatobá (Himenaea courbaril L.) nesse estudo pode ser considerado uma espécie rara com distribuição aparentemente agrupada, que tem sua dinâmica alterada em áreas secundárias, onde é favorecida. Esses fatores provavelmente tem relação direta com os padrões de dispersão de sementes e de pólen ou seja com o fluxo gênico. 


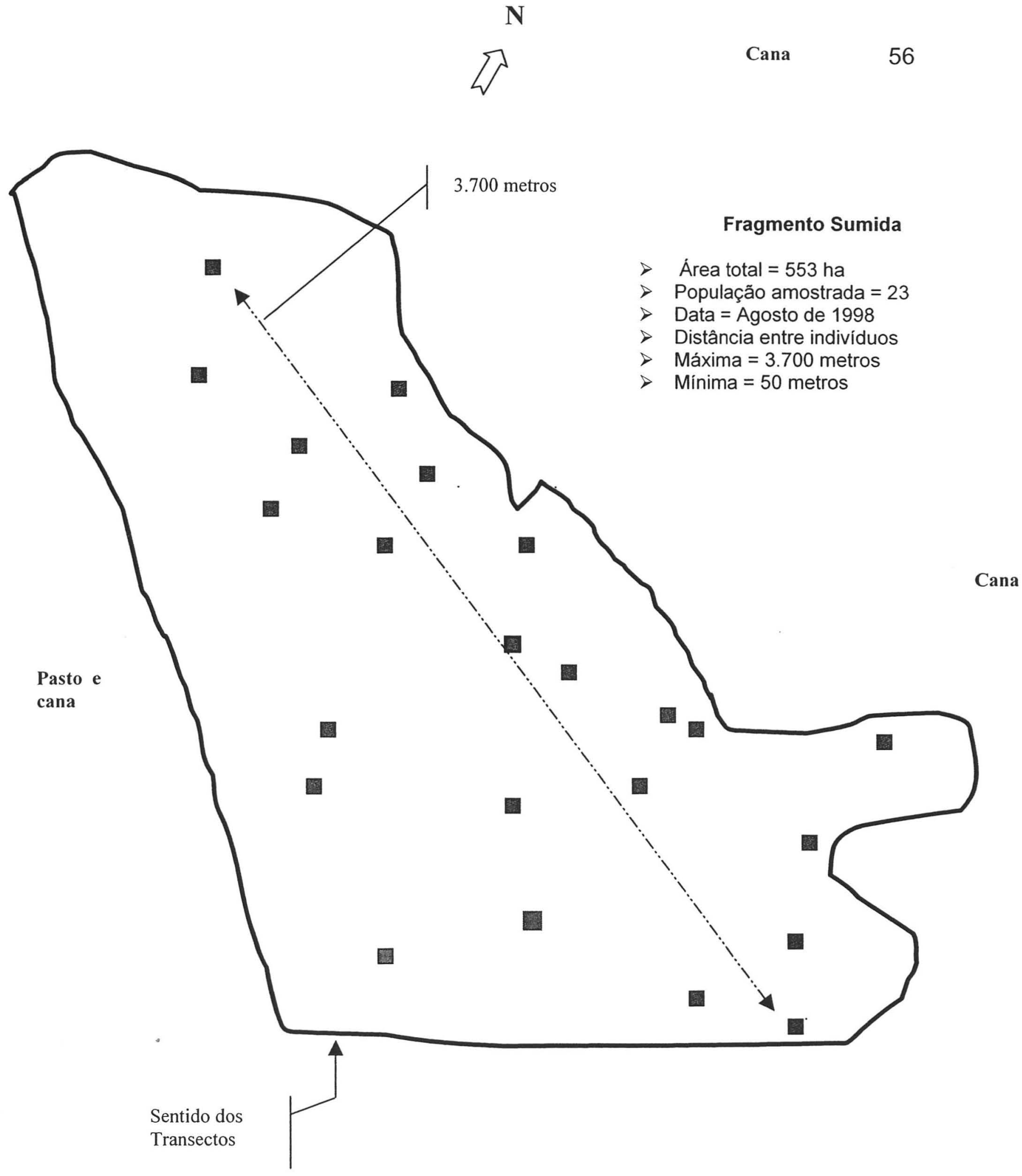

Distância entre os transectos (50 metros)

Figura.3 - Distribuição espacial de Hymenaea courbaril L. no fragmento Sumida 


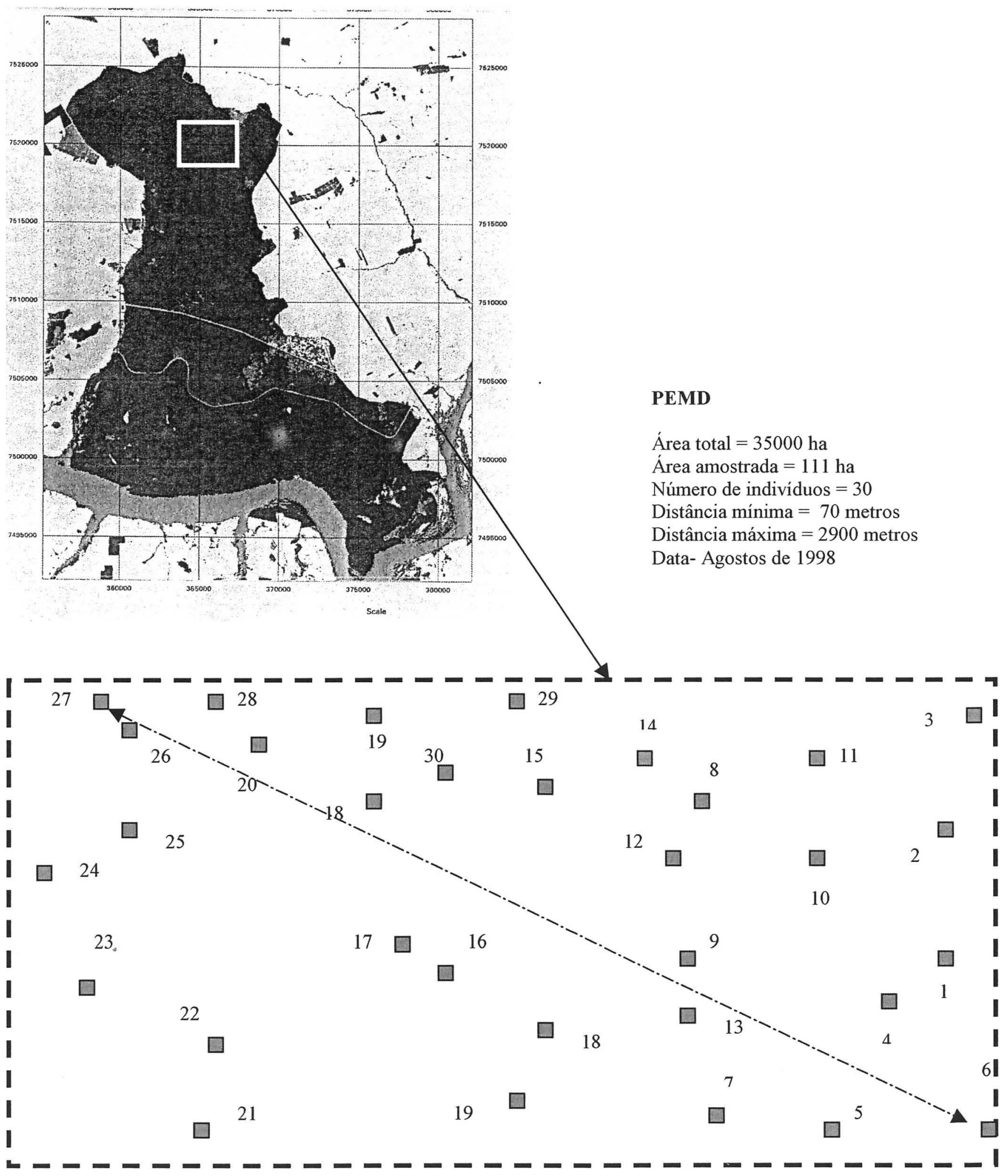

Figura 4 - Croqui com a distribuição espacial dos indivíduos adultos de $\mathrm{H}$. courbaril, no Parque Estadual do Morro do Diabo (PEMD) 


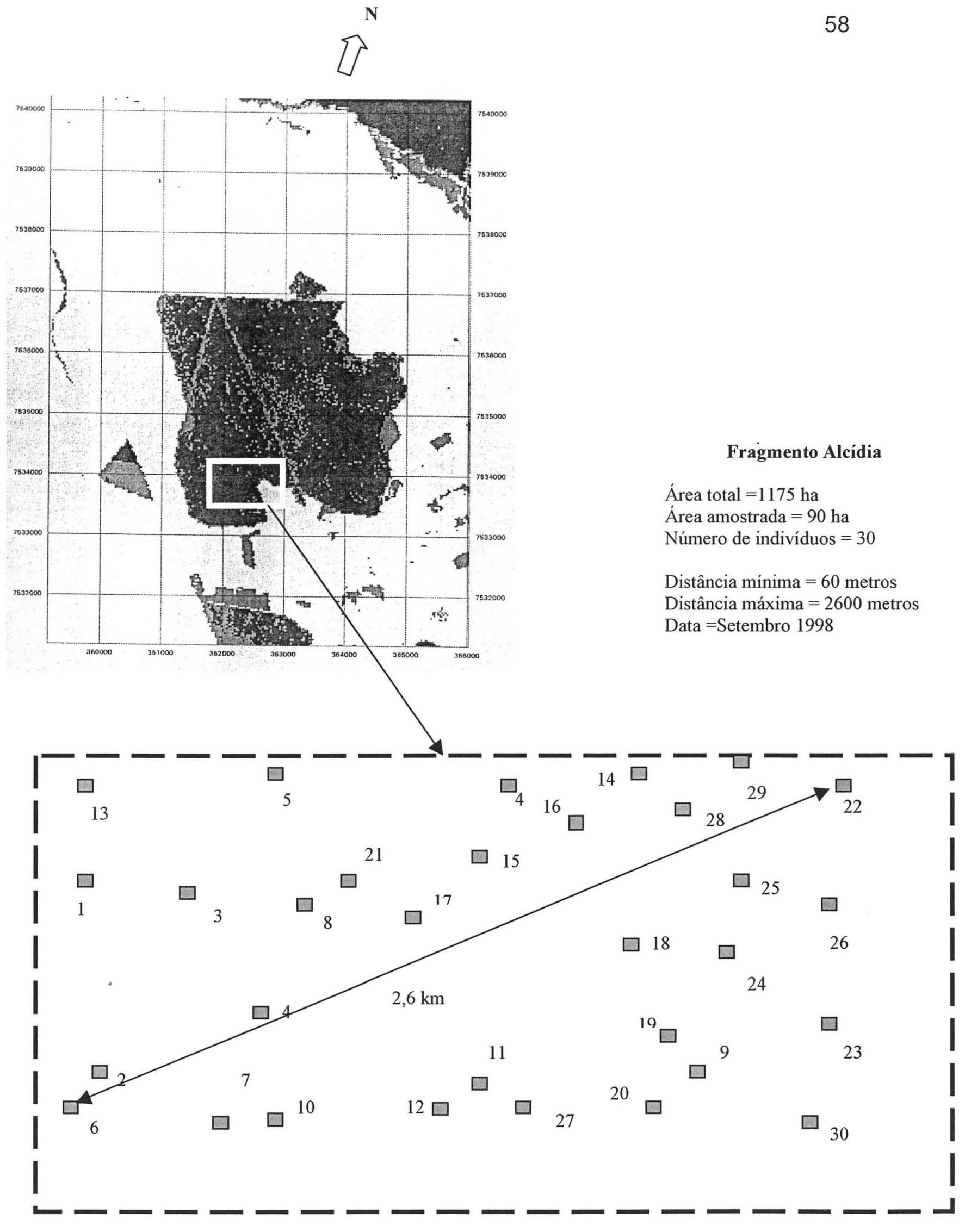

Figura 5 - Croqui com a distribuição espacial dos indivíduos adultos de $\mathrm{H}$. courbaril. no fragmento Alcídia. 
Fragmento Sumida -553 ha

Amostra da população do Fragmento Alcídia - 90 ha
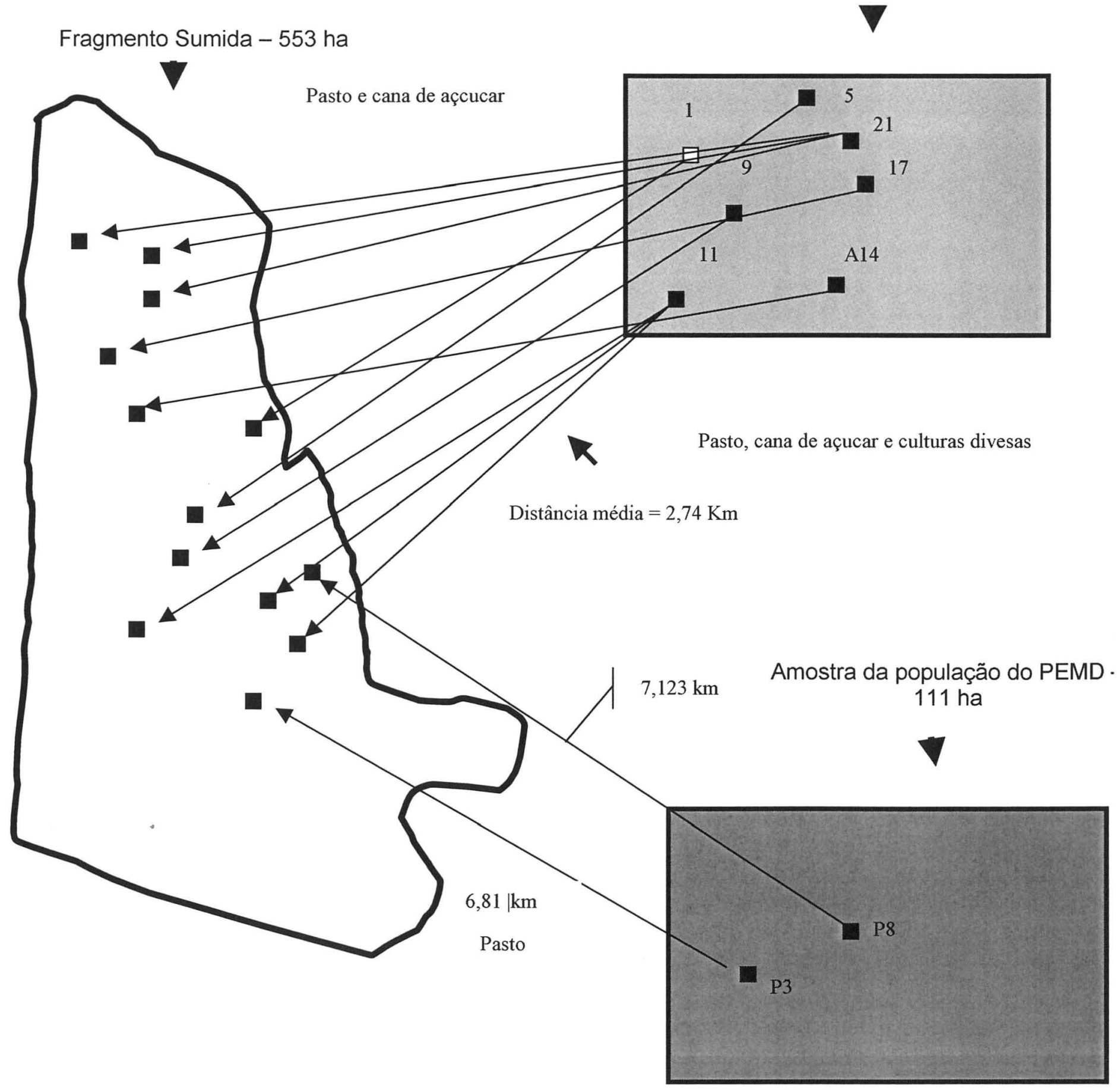

Figura 6 - Representação das distâncias de fluxo gênico entre as três populações estudadas (PEMD, Alcídia e Sumida, obtidas por meio de análise de paternidade. 


\subsubsection{Fenologia reprodutiva da espécie nas populações estudadas}

Aparentemente os intervalos de observação para os eventos da fenologia reprodutiva foram suficientes. Foi possivel, dentro do periodo de estudo, acompanhar os eventos de florescimento e frutificação de todas as árvores analisadas, tornando possivel fazer algumas inferências a respeito dos eventos reprodutivos das populações de jatobá (Hymenaea courbaril L.) existente nas três áreas estudadas.

Para os estudos em fenologia, o intervalo entre as observações de uma espécie ou de uma comunidade pode ser semanal ou quinzenal, sendo que alguns trabalhos usam observações mensais. Intervalos superiores a estes são desaconselháveis, pois corre-se o risco de não se observar eventos que se manifestem em curto espaço de tempo (Amaral, 1998).

Não foram encontradas referências a respeito de dados fenológicos do jatobá na região,sendo que as informações existentes se referem à outras áreas do estado de São Paulo ou de outras regiões do pais.

Parece ter existido uma certa sincronia na floração na região; no período estudado. O pico de floração nas três áreas estudadas foi entre os sete primeiros dias de maio para todos os anos analisados com exceção de 2001 , onde a florada ocorreu em janeiro. A frutificação permaneceu (frutos formados) entre os meses de setembro a dezembro, sendo que em dezembro só permaneceram com frutos árvores amostradas nos fragmentos; no PEMD todas as árvores monitoradas perderam todos os frutos em novembro.

As épocas de floração e queda dos frutos de jatobá (Hymenaea courbaril L.) são mencionadas, respectivamente, como novembro-janeiro, e setembro; por Lee \& Langenheim (1975); dezembro-janeiro, e outubro-novembro por Rizzini (1971) comenta que apesar de não haverem registros fenológicos extensos, aparentemente a frutificação ocorre em intervalos plurianuais irregulares (2 a 4 anos), e são sincronizados para a maioria da população, excetuando-se árvores isoladas ou ribeirinhas, que segundo o autor tendem a frutificar anualmente. Estes dados não 
condizem com a realidade da região, no que diz respeito ao periodo de amostragem, sendo que estes dados podem representar características específicas da região ou refletirem apenas eventos sazonais e discrepantes das referências existentes.

É possivel observar a alternância dos eventos reprodutivos (florescimento e frutificação ) dentro das áreas amostradas assim como entre os períodos de amostragem. Destacam-se as árvores que floriram e frutificaram durante todo o período de observação - frutificaram 4 vezes em quatro períodos de observação.

Foram coletadas sementes dos 23 indivíduos monitorados no fragmento Sumida. O pico de frutificação foi no segundo período de monitoramento (1999), sendo que $43,48 \%$ das árvores produziram frutos. O restante das sementes foi coletado nos demais períodos de observação.

A proporção de árvores que floresceram nas três áreas durante todo o período de amostragem pode ser visualizada na tabela 03.

Tabela 3. Número de indivíduos que floresceram nas três áreas (Sumida, Alcídia e PEMD) em 1999,2000 e 2001.

\begin{tabular}{cccc}
\hline Ano & Sumida & Alcídia & PEMD \\
\hline 1999 & $15(65,21 \%)$ & $21(69,8 \%)$ & $22(73,00 \%)$ \\
2000 & $12(52,17 \%)$ & $18(60 \%)$ & $16(53,33 \%)$ \\
2001 & $18(78,26 \%)$ & $20(66 \%)$ & $9(30,00 \%)$ \\
\hline
\end{tabular}


Só é possivel fazer uma correlação entre as árvores que floriram e frutificaram e as possiveis relações com o local onde cada uma se localiza, a partir do ano de 1999, tendo em vista que as árvores com fruto observadas no ano de 1998 não tiveram a floração observada Quando se iniciou a coleta de dados, no referido ano, foram coletados os frutos já desenvolvidos.

Não se observou diferença significativa entre a proporção de árvores que floriram nas três área de estudo, ou que floriram e não produziram frutos, não sendo possivel afirmar que exista alguma relação entre o tamanho das áreas e o sucesso reprodutivo das árvores contidas nas mesmas.

A exceção aos resultados supra referidos diz respeito ao número de árvores florescendo no mês de janeiro de 2001; é bastante discrepante se comparado às porcentagens de árvores que floresceram e não produziram frutos nos anos anteriores ou que floresceram e produziram frutos (esses dois eventos compreendem a somas dos florescimentos nas áreas 1 e 2).

No fragmento Sumida, $78 \%$ das árvores floresceram, sendo que apenas $9 \%$ dessas produziram frutos. No fragmento Alcídia, $70 \%$ das árvores analisadas floriram, sendo que 11,62 frutificaram. No PEMD $30 \%$ floriram e apenas $7 \%$ frutificaram, tabela 3.

Tabela 4. Número de indivíduos que frutificaram nas três áreas de estudo(Sumida, Alcídia e PEMD) em quatro periodos de amostragem.

\begin{tabular}{cccc}
\hline Ano & Sumida & Alcídia & PEMD \\
\hline 1988 & $21,74 \%$ & $46,67 \%$ & $66,67 \%$ \\
1999 & $43,48 \%$ & $53,33 \%$ & $56,67 \%$ \\
2000 & $43,48 \%$ & $43,33 \%$ & $46,67 \%$ \\
2001 & $9,00 \%$ & $11,62 \%$ & $7,00 \%$ \\
\hline
\end{tabular}


As porcentagens de árvores floridas nas três áreas de estudo coincidem com o fato de que parte das árvores que floresceram foram afetadas por uma sucessão de geadas no final de julho e início de agosto de 2000 , onde os frutos jovens em formação foram abortados. Parece haver uma resposta fisiológica ao insucesso reprodutivo das árvores afetadas pela geada.

Um aspecto que poder ser observado ao analisar a perda de frutos jovens nas áreas dos fragmentos, o que pode estar sendo expressa pela abundância de flores e a aparente maior suscetibilidade das árvores localizadas nos fragmentos a fatores físicos (climáticos), pode estar relacionado ao efeito de borda , pois a maior parte das árvores são emergentes dentro de uma estrutura via de regra alterada se comparada a estrutura vertical do PEMD, o que está relacionado ao histórico de perturbação das áreas, forma, tamanho e localização dos fragmentos.

Observações de campo em visita a outros fragmentos existentes na paisagem estudada, assim como em áreas do PEMD antropizadas, evidenciam a maior suscetibilidade destas áreas a eventos climáticos, pois a maior parte da árvores isoladas e existentes em outros fragmentos de tamanho equivalente aos analisados ou menores, foram severamente atingidas pelas geadas. As árvores localizadas em áreas de borda do Parque foram mais atingidas do que as localizadas no interior do mesmo.

Os dados de fenologia das árvores de Hymenaea courbaril L. mostram uma clara alternância de floração e frutificação entre os quatro anos estudados.

No fragmento Sumida $21,74 \%$ das árvores frutificaram mais de uma vez durente os quatrotro períodos de amostragem, $46,66 \%$ da população estudada no fragmento Alcídia e 50,0\% dos indivíduos da amostragem do PEMD.

Realtivamente poucas árvores frutificaram em todos os períodos; por outro lado a maior parte frutificou em um ou mais anos, fazendo com que o conjunto dos indivíduos que reproduziram a cada ano variasse bastante. Essa alternância ao se analisar o conjunto de árvores pertencentes ao universo amostral deste estudo pode 
estar relacionada a diversos fatores, entre eles variações microclimáticas, ação mais eficaz do polinizador ou a predação, ou mesmo sincronismo natural da espécie.

Numa comparação entre a proporção de árvores que frutificaram, aparentemente existe uma relação entre o tamanho das áreas e a ocorrência dos eventos reprodutivos, como pode ser observado na tabela 09.

Essas constatações tem diversas implicações, tanto ecológicas como genéticas. As implicações ecológicas podem ser quanto ao hábito do polinizador que terá que estabelecer diferentes rotas de vôo a cada ano e enfrentar diferentes distâncias médias de vôo entre árvores. Isso pode influir no potencial fluxo gênico entre as populações contidas no fragmentos florestais, tendo em vista que o polinizador tem de visitar diferentes áreas, devido à alternância no florescimento das árvores contidas nas mesmas. Da mesma forma podemos aplicar para os dispersores, levando-se em conta que os mesmos se deslocam em busca de abundância de alimento (frutos).

As implicações genéticas são claras quando observamos que os indivíduos contribuindo para a formação das coortes de um ano são muito diferentes dos próximos anos, fazendo com que provavelmente o pool gênico varie de ano a ano. Além do que, uma vez que poucos individuos se reproduzem a cada ano, a possibilidade de cruzamentos biparentais é bastante alta, mas estes devem variar a cada ano.

A partir dessas observações, podemos ver que, para uma análise criteriosa do sistema de cruzamento do jatobá, deveriam ser observadas as taxas de cruzamento entre diferentes anos. 


\subsubsection{Interações da espécie com a fauna; implicações na dispersão, predação e polinização de Hymenea courbaril $L$.}

Durante o período de coleta de dados foram registrados direta e indiretamente, a presença de diversos animais próximos às árvores de $H$. courbaril quando as mesmas encontravam-se dispersando sementes. Foram registrados animais se alimentando dos frutos, assim como vestígios nas fezes dos frutos consumidos.

Sob as árvores dispersando frutos, foram observadas fezes e pegadas de várias espécies, como anta (Tapirus terrestris), veado (Mazama sp), cotia, (Dazyprocta azarae), queixadas (Tayassu pecari) e cachorro do mato (Cerdocyon thous) Observouse diretamente a anta, vedado, cotia e queixada alimentando-se dos frutos de jatobá caídos no chão. Também foram observados macaco prego (Cebus apella) na copa das árvores, se alimentando de frutos maduros.

A maior parte desses registros foram feitos nas áreas do PEMD e no fragmento Alcídia. No fragmento Sumida, foram observados apenas vestígios indiretos de predação de frutos, não tendo sido possivel identificar os possiveis agentes. Nessa mesma área foram observadas pegadas de anta (Tapirus terrestris) e de veado (Mazama $s p$ ) nas estradas que circundam o fragmento, sugerindo que os mesmos podem vir a adentrar ao mesmo.

A avaliação da ação efetiva da mastofauna na dispersão e/ou predação dos frutos e sementes do jatobá não fazem parte dos objetivos deste estudo. Porem foram constatadas essas interções, durante o desenvolvimento do mesmo, o que pode permitir que se faça algumas inferências a respeito das possíveis interações entre o componente faunístico e a dinâmica do jatobá assim como o seu impacto sobre a estrutura dos fragmentos de floresta na paisagem estudada.

No que se refere à dispersão e a predação, diversos autores documentaram o papel desempenhado por mamíferos (Redford 1997). O mesmo autor revisa sobre o importante papel na predação de sementes da ação de queixadas, veados e antas., 
onde relata sobre a enorme quantidade de sementes que esses grandes ungulados consomem. Merece destaque nessa análise as queixadas por se movimentarem em grandes bandos influindo nas mudanças da composição e da estrutura da floresta e que hoje são bastante raros. No exemplo do estudo de caso deste trabalho isso é um fato que se constata.

Nas áreas de coleta no PEMD foram observadas diversas vezes a ocorrência desses animais em bandos e se alimentando de frutos e sementes de jatobá e provavelmente de plântulas existentes nessas áreas, o que não fôra observada nas demais áreas de coleta (Sumida e Alcídia) Isso pode estar relacionado apenas à casualidade da freqüência de observações ou pode refletir indícios de que esses animais já não agem com a mesma intensidade nas duas áreas supra mencionadas, seja pelo isolamento das mesmas com relação à área do PEMD, seja pela pressão de caça nessas áreas, ou ainda pela descaracterização dos ambientes. Um indicativo desses fatos pode estar relacionado às alterações nas taxas de recrutamento nas áreas do fragmento Sumida, onde observa-se um número muito grande de regenerantes que podem estar relacionados à alteração nos padrões de predação onde a ausência deste e de outros grupos faunísticos aliados às alterações edáficas .

Redford, 1997 relata o papel desempenhado pelas cotias, que além de serem grandes predadores também são boas dispersoras de sementes, principalmente para sementes grandes que é o caso do jatobá. O mesmo autor menciona que esses animais com população em desequilibrio (aumento na população) podem exercer um efeito negativo sobrepredando as sementes presentes no ambiente. Efetivamente, se considerarmos as cotias como dispersoras as mesmas tem potencial para transportar sementes grandes como as do jatobá em pouco quantidade e a curtas distâncias. Levando-se em conta que esses animais evitam se expor à condições de risco, como a matriz desprovida de cobertura florestal, acabam sendo responsáveis por um provável fluxo gênico a curta distância e dentro de uma mesma área (fragmento).

Com relação a Anta (Tapirus terrestris), constatou-se nesse estudo a dispersão afetiva de sementes de jatobá, apesar de todos os relatos encontrados na literatura não se referirem a Anta como dispersor das sementes de jatobá. Olmos (1997), relata que o papel das antas como predadores e dispersores de sementes começou a ser 
estudado recentemente. Numa ampla revisão o mesmo autor sugere que as antas selecionam alimento de maior qualidade quando disponível, uma hipótese apoiada pelo fato de que concentrações de frutos são ativamente procurados e determinam padrões de forrageamento. Esse aspecto de comportamento encaixa-se ao padrão de oferta de alimento que os frutos de jatobá representam, tendo em vista que os mesmos amadurecem de forma heterogênea numa mesma árvore e entre as árvores, disponibilizando alimento em locais e momentos distintos, fazendo com que os animais tenham de se deslocar para aproveitar a oferta de alimento. (figura 7)

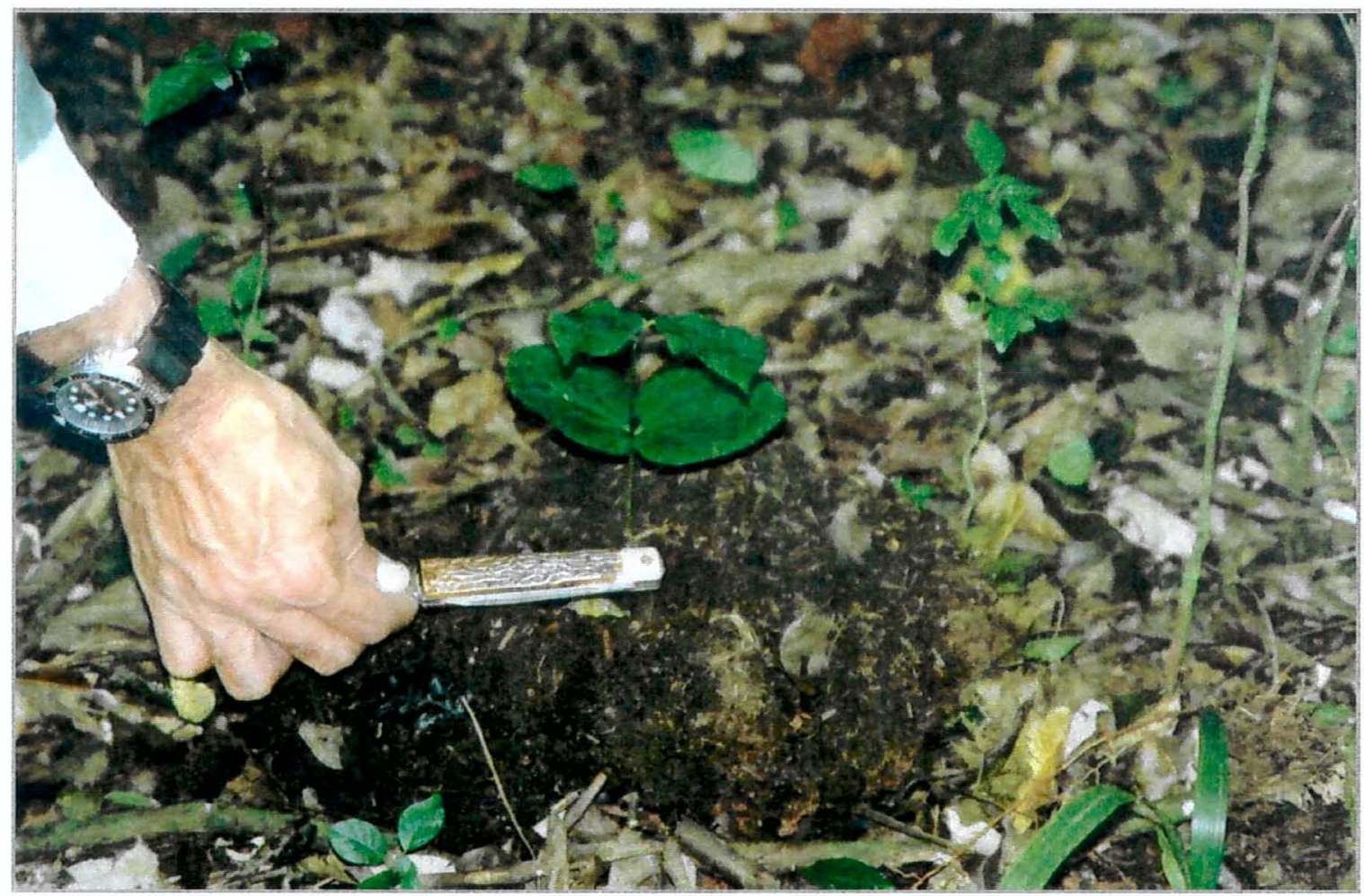

Figura 7 - Plantula de $H$. coubaril geminando nas fezes de Anta (Tapirus terrestris) no iinterior da floresta do PEMD $\left(22^{\circ} 25^{\prime} 33^{\prime \prime} \mathrm{S}, 52^{\circ} 24^{\prime} 42^{\prime \prime} \mathrm{W}\right)$. 
Brisola (1989), num estudo sobre habitos alimentares de Tapirus terrestris e sua atuação como dispersores de sementes no PEMD, observou que a mastigação danifica as sementes grandes e duras do jatobá, que são em sua maioria cuspidas após a remoção da polpa e embora algumas sejam totalmente mastigadas e engolidas. As observações deste estudo confirmam que as sementes foram ingeridas intactas ou sofreram dano que não às inviabiliza-se, vindo a germinar (figura 07).

Olmos (1997) em revisão sobre hábitos alimentares das antas, menciona que ao contrário dos ruminantes a maioria das sementes ingeridas pelas antas não são mortas e sobrevivem à passagem através do sistema digestivo e que as sementes ingeridas permanecem um longo tempo dentro do trato digestivo, variando de 4 a 21 dias. Portando as sementes que sobrevivem efetivamente são dispersas, levando-se em conta que esses animais possuem uma área de uso muito vasta, pode-se inferir sobre o potencial dos mesmos como promotores de fluxo gênico do jatobá e de outras espécies

Olmos (1997), menciona que as antas tem potencial de produzir áreas de acúmulo "seed shadows" muito complexos e remotas, devido à impossibilidade das sementes serem transportadas por muitos quilômetros e ao fato das sementes serem defecadas a intervalos variados, mesmo quando ingeridas ao mesmo tempo, maximizando seu espalhamento. O mesmo autor salienta o aspecto, além dos já mencionados, de que as antas podem dispersar um grande número de sementes ao mesmo tempo podendo chegar a centenas. As plântulas vivas encontradas algumas vezes germinando a partir das fezes de antas mostram que essa tem sucesso em transportar sementes vivas o que se confirmado neste estudo, pelo fato de terem sido registras diversas plantulas sobr ás fezes de anta e em locis ditintos.

Vários autores documentaram o importante papel desempenhado pelas grandes aves e mamíferos terrestres na dispersão de sementes de plantas tropicais. Baseado em seu trabalho no Panamá, afirmam que: "sem dúvida a dispersão por intermédio de animais se tornará critica para o restabelecimento e manutenção 
demográfica de muitas ou da maioria das espécies alógamas da floresta tropical". (Olmos ,1997)

Dentro do contexto de paisagens formadas basicamente por fragmentos florestais, o papel dos dispersores torna-se um ponto crítico na manutenção da diversidade. Tendo em vista que serão os responsáveis por parte da manutenção da diversidade genética das populações contidas nessas áreas através da promoção de fluxo gênico entre e dentro das populações. No caso especifico deste estudo merece destaque o possivel potencial exercido pela Anta, pelas peculiaridades mencionadas anteriormente e se considerarmos sua capacidade de se deslocar entre os fragmentos florestais.

Reis (1996), baseado nos trabalhos de Bawa et al. (1984): Terborgh (1980): Bawa 1990 e Morellato (1991), ressalta a importância de se considerar que os processos microevolutivos de cada espécie acontecem numa determinada comunidade ou ecossistema e, portanto, diversos organismos e componentes abióticos do ecossistema estão envolvidos de forma dialética. Tal aspecto é essencialmente relevante em ecossistemas tropicais, onde, na maioria das espécies de plantas, os eventos relativos à movimentação de alelos são mediados pela fauna.

Vários fatores podem atuar na formação de padrões de distribuição dos genótipos de $H$. coubaril. A densidade e distribuição espacial dos indivíduos adultos podem afetar ao longo do tempo o grau de aleatoriedade dos cruzamentos, tendo em vista que em fragmentos a distância de fluxo gênico tanto via polinização quanto via dispersão de sementes assim como a eliminação de microhabitats especificos. Somados aos fatores climáticos, são fatores que podem levar a uma alteração nos níveis de agregação alélica influindo na produção de flores, nas polinização e na dispersão de sementes.

Portanto, o fluxo gênico via sementes deve ser considerado como de longa distãncia, pela anta, que tem potencial para cruzar a paisagem interligando fragmentos próximos, e também à curta distãncia considerando a ação das cotias. 


\subsection{Análise Genética}

\subsubsection{Variação genética e Sistema Reprodutivo}

Para os 05 locos de microssatélite analisados, as 03 populações estudadas apresentaram niveis elevados de diversidade gênica $\left(H_{\mathrm{e}}\right)$ variando entre 0,821 e 0,872. A heterozigosidade observada $\left(H_{0}\right)$ variou entre 0,789 e 0,895 (tabela 5). A média de alelos por loco foi também considerada alta (12). Os valores de $F_{\text {Is }}$ estimados, baseados nas freqüências gênicas, foram relativamente baixos se comparadas às encontradas para outras espécies tropicais, sendo que para a população Sumida foi negativo, o que indica haver uma existência maior de indivíduos hetrozigotos nesta população, quando comparada com as outras duas analisadas. (tabela 05).

Tabela 05. Estimativa de variabilidade genética em adultos (Ad), em três populações de Hymenaea courbaril, e progênies na Sumida sendo $N$ : número de indivíduos amostrados; $L$ número de locos de microssatélites; $A$ : número médio de alelos; Ho: heterozigosidade observada; He: heterozigosidade esperada (divergencia gênica); f: índice de fixação de Wright, $\mathrm{N}_{\mathrm{e}}$ tamanho efetivo populacional

\begin{tabular}{ccccccccc}
\hline Pop & & $\mathrm{N}$ & $\mathrm{L}$ & $\mathrm{A}$ & $\mathrm{Ho}$ & $\hat{H}_{e}$ & $\mathrm{~F}_{\text {IS }}$ & $\hat{N}_{e}$ \\
\hline PEMD & Ad & 30 & 5 & 11,2 & 0.816 & 0.821 & 0.0066 & 29,80 \\
Alcídia & Ad & 30 & 5 & 13,2 & 0.789 & 0.872 & 0.0965 & 27,36 \\
Sumida & Ad. & 23 & 5 & 11.6 & 0.895 & 0.851 & -0.0537 & 24,31 \\
Média & & & & 12.0 & 0.833 & 0.848 & 0.0176 & \\
\hline
\end{tabular}

Observa-se uma alta riqueza alélica, isto é, alto número de alelos por locos nas populações.(tabela 05) a hetrozigosidade observada foi sempre muito próxima da a heterozigosidade média observada, reflexo dos baixos índices de fixação encontrado. A heterozigosidade esperada (diversidade gênica) pode ser considerada bastante alta 
para uma espécie de polinização e dispersão zoocórica, acima da média observada para espécies arbóreas tropicas (Maltez, 1997). Entretanto deve-se ressaltar que o tipo de marcador molecular utilizado (SSR) permite a obtenção de estimativas de $\hat{H}_{e}$ numericamente superiores àquelas obtidas através de marcadores isoenzimáticos, mais comumente encontrados na literatura. Valores próximos aos observados nesse estudo foram encontrados para Copaifera langsdorffii, usando os mesmo marcador genético em Ciampi (1999).

Esses resultados podem estar relacionados ao número de alelos encontrados, mesmo levando-se em conta que foram utilizados cinco locos, sendo que o número médio de alelos por loco também estão de acordo com valores encontrados para espécies arbóreas tropicais genotipadas com amrcadores microssatélite (Maltez 1997).

É possivel dizer que a espécies, nas populações estudadas, possui alta diversidade genética, provavelmente relacionada aos efetivos mecanismos de fluxo gênico e à polinização cruzada.

A pequena discordância, se bem que próxima a zero, dos valores de $F_{\text {IS }}$ para os locos analisados, obtenção de valores positivos e negativos, podem estar evidenciando a ocorrência de outros mecanismos atuando nas populações estudadas, considerandoas como uma metapopulação, amarrados ao sistema reprodutivo ou seleção diferencial para heterozigotos. Isso pode ser um indicativo de que se deva aumentar a amostragem de locos para uma análise mais minuciosa e segura dos fenômenos envolvidos na definição da estrutura genética dessas populações.

A associação entre as estimativas obtidas para os indivíduos jovens (progênies) e adultos na população Sumida (tabela 06), pode ser interpretada a partir da origem da amostra das progênies coletadas de indivíduos adultos. Não é possível inferir sobre a similaridade entre a estrutura atual dos adultos e dos jovens, tendo em vista que os eventos que deram origem às progênies provavelmente são diferentes dos que deram origem à estrutura dos adultos. Isso supondo que as atuais populações de adultos podem ser consideradas remotas e anteriores ao processo de fragmentação, sendo que os eventos como seleção natural e deriva, fluxo gênico e migração a densidade e 
distribuição espacial dos indivíduos eram diferentes dos encontrados hoje. O mesmo vale para a população Alcídia e para os demais fragmentos da paisagem, considerando que o jatobá é uma espécie valorizada', que já sofrera pressão exploratória no passado e queainda hoje é explorada ilegalmente.

As populações mínimas viáveis podem ser estudadas pelos modelos tradiconais de dinâmica de populações e demografia, contudo, a sobrevivência a longo prazo das populações das populações está diretamente relacionado ao seu grau de variabilidade genética. Em populações fechadas, a presença de um pequeno número de indivíduos mantido sobre diversas gerações levará ao aumento da endogamia , com suas conseguências deletérias. Por outro lado, o número de indivíduos é um parâmetro decisivo na determinação da quantidade de variabilidade genética que pode ser mantida numa população. Este fato, por sua vez, influencia na probabilidade de sobrevivência a longo prazo de uma população, pois a variabilidade genética é requisito básico para as adaptações evolutivas às mudanças ambientais .

Um conceito relevante para estas questões é o tamanho efetivo de uma população. Esta é uma medida do número de indivíduos que estão contribuindo com seus genes para próxima geração, ou seja, o número de indivíduos que efetivamente se reproduz, contribuindo para a variabilidade genética das geraçōes subsequentes. A relação entre o tamanho efetivo e o tamanho total de uma população depende da variância do sucesso reprodutivo; esse, por sua vez, depende do sistema de acasalamento da espécie e da longevidade. Cabe ressaltar que a variação genética numa população não é apenas função de seu tamanho efetivo, mas também do tipo de variação genética considerada e da natureza da seleção atuando nesta variação, o que nos dias atuais representa a intensificação da desestruturação das paisagens naturais onde a fragmentação é um dos aspectos mais intensos assim como as interações antrópicas na matriz que envolvem os fragmentos de habitat.

$\mathrm{Na}$ tabela 05 estão os valores encontrados para as estimativas do tamanho efetivo populacional, dando uma idéia da amplitude da amostragem genética realizada nas populações de $H$. courbaril. Os resultados apontam que a deriva genética para os 2 fragmentos estudados, (Sumida e Alcídia) é similar ao da reserva (PEMD), mostrando que a amostragem foi adequada para apreender a variabilidade genética ds 
populações que, provavelmente os individuos adultos do fragmento são remenescentes à fragmentação. Cabe ressaltar, que o Ne estimado para a população Sumida foi maior que o N.indicando um alto índice de heterozigosidade o que pode estar relacionado aos efeitos antrópicos, os quais podem ter favorecido a persistência na área de indivíduos fruto de uma deriva que favoreceu os heterozigotos.

Tabela 6. Estimativa de parâmetros de sistema reprodutivo, sendo $\hat{t}_{m}$ taxa de cruzamento multiloco, $\hat{t}_{s} t s$ : taxa de cruzamento baseada na média de locos individuais; $r p$ : correlação de paternidade dentro de progênies resultante de cruzamento e $r$ : correlação entre taxa de cruzamento dentro de famílias, para a população Sumida

$$
\hat{t}_{s}, \hat{t}_{m} \text { e } \hat{t}_{m}-\hat{t}_{s}
$$

\begin{tabular}{cc}
\hline & Sumida \\
\hline$\hat{t}_{m}$ & $0,991(0,020)^{*}$ \\
$\hat{t}_{s}$ & $0,977(0,036)$ \\
$\hat{t}_{m}-\hat{t}_{s}$ & $0,014(0,033)$ \\
$r_{p}$ & $0,146(0,041)$ \\
$r_{\mathrm{t}}$ & $0,0058(0,023)$
\end{tabular}

"Entre parênteses : erro-padrão estimados através de 10.000 "bootstraps"

Os resultados referentes às taxas de cruzamento (multilocos e média de locos individuais) estão apresentados na tabela 06. As taxas de cruzamento baseadas nas médias de locos individuais ( $t_{\mathrm{s}}$ ) foram estimadas a partir do modelo de reprodução mista (Ritland \& Jain 1981). E é próxima da unidade considerando seus padrões. A taxa de cruzamento entre individuos aparentados representada pelas diferenças de $t_{m}$ e ts, foi de 0,014 para Sumida (tabela 06), e mostram que nas populações analisadas,, não é comum o cruzamento entre indivíduos aparentados, e que a espécie, em específico nessa população, são predominantemente alogamas. Isso é coerente com os trabalhos de biologia reprodutiva com a espécie (Crestana \& Mariano, 1985) 
A correlação nas estimativas de $r_{p} .0,146$, indicam que há baixa ocorrência de irmãos germanos em famílias maternas para a populção $H$. coubaril. Os valores de $r_{t}$ na população Sumida estão próximos de zero, o que é um indicativo de que não houve auto-fecundação..

Para considerarmos os fragmentos e o PEMD como metapopulações, para uma espécie como o jatobá, deve-se entender como se dá o fluxo gênico entre os fragmentos, tanto por sementes (recolinização de fragmentos pequenos), assim como por pólen, não permitindo que haja a oçorrência de deriva.

\subsubsection{Estrutura Genética e Fluxo Gênico}

O índice de fixação (FiS) foi estimado com 05 locos SSR, considerados todos os adultos amostrados das três áreas de estudo (Sumida, Alcídia e PEMD) mais as progênies da população do Fragmento Sumida

O valor de $\hat{F}_{s t}$ foi de 0.0664 . A estimativa foi significativamente diferente de zero (tabela 07). Esta significância pode ter ocorrido, apesar dos baixos valores observados, devido aos grande número de alelos existentes nos locos microssatélites, o que torna o teste estatístico extremamente sensivel.

O parâmetro $N_{m}$, baseado na estimativa de $\hat{F} s t$ foi de 3,51 ; indicando alta taxa de migrantes; o que pode ser um indício de que as populações ainda não se encontram em processo de diferenciação. 
Tabela 7. Estatística $F$ de Wright e o número de migrantes por geração $\left(N_{m}\right)$ para as três populações naturais de Hymenaea C. (PEMD, Sumida e Alcídia), considerando o intervalo de confiança de $95 \%$ de probabilidade.

\begin{tabular}{ccccc}
\hline & $\hat{F}_{I S}$ & $\hat{F}_{I T}$ & $\hat{F} s t$ & $\mathrm{Nm}\left(\hat{F}_{s t}\right)$ \\
\hline Sob todos os locos & 0,0231 & 0,0880 & 0,0664 & 3,51 \\
Superior (IC 95\%) & 0.155 & 0.2366 & 0.0995 & 3,86 \\
Inferior (IC 95\%) & -0.0594 & -0.0033 & 0.0420 & 2,47 \\
\hline
\end{tabular}

A distribuição da variabilidade genética entre e dentro das populações $(\hat{F} s t 0,066)$, pode ser considerada coerente comparando-se com valores obtidos para 83 outras espécies arbóreas tropicais, (Maltez, 1997). A maior parte da variabilidade encontra-se dentro das populações, havendo pouco divergência entre elas.

As estimativas de diferenciação genética relativamente baixas obtidas neste estudo sugerem um fluxo gênico elevado entre essas populações, o que se confirma pela estimativa de $N_{m}$ via $\hat{F}$ st.

Os resultados obtidos são coerentes, se considerarmos, que se trata da análise de indivíduos adultos, remanescentes à fragmentação eque a espçeis possui vetores de fluxo gênico via polem e sementes a longa distância.

\subsubsection{Análise de paternidade}

Para 113 progênies (49,13 \%do total) analisadas na população do fragmento Sumida, e com base na exclusão de paternidade, foi encontrado pelo menos um provável progenitor paterno. Para $50,87 \%$ dos indivíduos analisados não foram encontrados os prováveis pais (progenitor paterno). 
Das 113 progênies das quais foram detectados os prováveis progenitores paternos, $86,7 \%$ são provenientes da própria população contida no fragmento Sumida; $11,5 \%$ provenientes do Fragmento Alcídia e 1, 8\% provenientes do PEMD.

Os indivíduos identificados como prováveis progenitores localizam-se a uma distância máxima de 7123 metros (PEMD) e 4232 metros (Alcidia) da população Sumida e a distância máxima entre os indivíduos adultos amostrados dentro da população Sumida é de 2075 metros. Por se tratar de análise de progênies provenientes de polinização aberta, a distância de fluxo gênico, para as populações analisadas, é de $7,123 \mathrm{Km}$, tendo em vista que foram identificados dois prováveis pais no PEM (tabela 8 ).

Tabela 08. Probabilidades de paternidade com as quais indivíduos adultos de Hymenaea $C$. do PEMD (P) e Alcídia (A) são considerados progenitores de progênies do Sumida, . Estimativas obtidas a partir de diferentes probabilidades a priori $(P)$ e distância entre os indivíduos e prováveis progenitores em metros.

\begin{tabular}{cccc}
\hline $\begin{array}{c}\text { Indivíduos } \\
\text { (Progênies) }\end{array}$ & $\begin{array}{c}\text { Provável } \\
\text { progenitor }\end{array}$ & $\begin{array}{c}\text { Probabilidade de } \\
\text { Paternidade } \\
(0,5)\end{array}$ & Distância dos pais (m) \\
\hline S15-9 & A1 & 0,999988 & 2100 \\
S11-7 & A5 & 0,999883 & 2357 \\
S4-3 & A9 & 0,999326 & 3320 \\
S7-1 e & A11 & $0,999678 \mathrm{e}$ & 1910 \\
S7-2 & & 0,999488 & 1970 \\
\hline S18-5 & A14 & 0,999957 & 2520 \\
S9-7 & A17 & 0,999919 & 1415 \\
\hline S13-1, & & 0,999999 & 2240 \\
S13-2 & A21 & 0,999956 & 3270 \\
S18-8 & & 0,999754 & 2359 \\
\hline S18-5 & P3 & 0,999997 & 7123 \\
S20-1 & P8 & 0,999949 & 6810 \\
\hline
\end{tabular}


Foi observado ainda que alguns indivíduos da população de $H$. Courbaril da população Sumida apresentaram sucesso reprodutivo muito superior aos de outros indivíduos da mesma população. Foi o caso dos adultos $\mathrm{S} 2$ e $\mathrm{S} 12$ identificados como prováveis pais de 10 das progênies analisadas (4,35\%), \$3 com 08 (3,48\%), S4-\$5 e S6 com $6(2,6 \%)$. Cabe considerar que foram analisados 230 progênies e que foram identificados como prováveis pais em 49,13 \% das progênies, o que possibilita inferir sobre a probabilidade de ter havido fecundação por pólen proveniente de árvores não amostradas e que não pertencem à população Sumida, já que todos os progenitores maternos (plantas adultas) deste fragmento foram amostrados. Isso permite cogitar que o fluxo gênico via pólen seja mais amplo do que o que foi detectado nesse estudo.

Outro aspecto a ser considerado refere-se à alta porcentagem de indivíduos identificados como sendo prováveis progenitores paternos, pertencentes à mesma população. Dos 113 prováveis progenitores paternos identificados $10,6 \%$ (12 indivíduos) foram identificados como prováveis progenitores pertencentes às outras duas populações estudadas (Alcídia e PEMD) e 89,4\% (101 indivíduos) foram identificados como sendo oriundos da própria população Sumida, onde vários individuos foram identificados como sendo progenitores de mais de uma progênie.

As distâncias entre os indivíduos (progenitores maternos) dentro do fragmento Sumida variam entre 40 e 3700 metros, quando relacionadas à proporção de indivíduos identificados como progenitores paternos cuja distância variou entre $123 \mathrm{e}$ 1430 metros dentro do fragmento, demonstram que provavelmente o polinizador(s) forrageam com grande intensidade dentro da área.

Considerando os resultados dos parâmetros genéticos obtidos neste estudo, os quais demonstram ainda não haver problemas com as populações estudadas, o fato de a maior parte dos progenitores paternos terem sido identificados dna mesma população pode representar um problema no futuro como, perda de alelos por deriva genética e endogamia por cruzamento de indivíduos aparentadso se não se mantiver a conectividade entre os fragmentos. 


\subsubsection{Aspectos relacionados a conectividade funcional e estrutural}

Perecin (2000), numa revisão sobre fluxo gênico, descreve que na literatura o termo é usado com vários sentidos. Alguns autores se referem ao fluxo gênico como um evento raro que ocorre entre populações divergentes e isoladas geograficamente, ou se refere a troca de pólen entre plantas no processo normal de reprodução realizado na escala de alguns metros.

A definição da existência de fluxo gênico, assim como sua intensidade, é um fator de suma importância quando se discute o aspecto da fragmentação. Isso tendo em vista que essa medida pode revelar o verdadeiro grau de conectância (conectividade funcional) e sobre a porosidade da paisagem analisada e consequênte sustentabilidade das populações contidas nessas áreas.

Nesse estudo, é possivel estabelecer alguns relações com alguns modelos teóricos para explicar a possivel dinâmica de fluxo gênico na paisagem. Alguns modelos tem sido propostos para tentar explicar como o fluxo gênico ocorre entre populações estruturadas de diferentes maneiras.

No modelo de continente-ilha, o movimento dos alelos ocorreria unidirecionalmente de uma população grande para um população menor e isolada, o que, neste estudo, parece ser um modelo possivel, tendo em vista que a maior parte dos fragmentos existentes na paisagem são pequenos. Os fragmentos com tamanho suficiente para conter populações viáveis seriam fonte de gametas e progágulos e que foi detectado fluxo gênico proveniente das áreas maiores - Alcídia e PEMD. Nesse caso, ao se pensar na paisagem como um todo, o que varia é o grau de isolamento, já que algumas áreas podem estar demasiadamente isoladas, impossibilitando o fluxo gênico $O$ modelo de ilhas considera que o movimento é multidirecional e ao acaso num grupo de populações pequenas. Nesse caso, a situação diagnosticada nesse estudo poderia ser considerada, supondo que todos os fragmentos contivessem populações, nesse caso de Hymenaea courbaril. No caso, o grau de isolamento possibilitaria o fluxo 
gênico entre populações, o que só poderia ser verificado aumentando a amostragem com relação ao número de áreas estudas e com diferentes distribuições na paisagem.

No modelo de alpondras ("stepping stones"), cada população somente recebe migrantes das populações vizinhas a ela. No caso da paisagem estudada, também seria um modelo aceitável, levando-se em conta o gradiente de distâncias existentes, onde possivelmente existem grupamentos de fragmentos próximos o suficiente entre si para que hajam trocas gênicas. em outro caso podem estar distantes o suficiente de outras áreas que possa vir a impossibilitar o fluxo, se considerarmos a distância de 7 , $2 \mathrm{~km}$ como a distância máxima de fluxo gênico via pólen. $O$ modelo de isolamento por distância que considera que há uma população grande e contínua, na qual a troca de alelos ocorre ente os vizinhos próximos, nesse caso fragmentos grandes poderiam ser considerados como as fontes e os pequenos e periféricos o destino(escoadouro) - 0 PEMD seria fonte para o Alcidia e para o Sumida (o que fora detectado).

Porém o modelo que mais se aplicaria ao caso da paisagem do Pontal do Paranapanema, para a espécie jatobá, seria o modelo de alpondras, tendo em vista que a maior parte dos fragmentos são pequenos, com baixos índices de conectividade.

Essas taxas não são fáceis de se estimar no campo. Por exemplo, uma população que vive em um ambiente-escoadouro pode ser considerada como fonte se for amostrada em um periodo subsequente a uma catástrofe natural. Outro problema é que não é fácil determinar o que é um habitat bom para uma determinada espécie.

É possível fazer uma análise generalizada a respeito da estrutura da paisagem estudada e realizar conexões entre os diferentes parâmetros, tanto estruturais quanto funcionais, quando se pensa na conectividade dessa paisagem. Fisicamente a paisagem analisada encontra-se fragmentada, e em muitos casos pode-se concluir que os fluxos biológicos sejam alterados, podendo ser impossibilitados entre as manchas de habitat representadas pelos fragmentos florestais. Dentro deste contexto é apropriado lançar mão do conceito de conectividade (Urban et al. , 2000). No caso especifico deste estudo, estruturalmente a paisagem apresenta índices relativamente baixos, que variam dependendo da escala do observador. Por outro lado, as medidas obtidas para os parâmetros de fluxo gênico indicam que essa mesma paisagem está 
funcionalmente conectada, demonstrando que a ausência de conexões espaciais não implicam obrigatoriamente na ausência de fluxo gênico, conforme pode ser visualizado na tabela 09.

Tabela 09. Medidas de conectividade funcional e estrutural . ( $\mathrm{Nm})$ fluxo gênico aparente via Fst; (F.G) distância em metros do fluxo gênico via pólen dentro do fragmento e entre fragmentos em metros; (IC).;índice de conectividade

\begin{tabular}{|c|c|c|c|c|}
\hline \multicolumn{5}{|c|}{ Conectividade } \\
\hline \multicolumn{2}{|c|}{ Estrutural (IC) } & \multicolumn{3}{|c|}{ Funcional } \\
\hline \multirow{2}{*}{ Sumida } & \multirow[t]{2}{*}{ Alcidia } & \multicolumn{2}{|c|}{$\mathrm{FG}$} & \multirow[b]{2}{*}{$\mathrm{Nm}$ (Fst) } \\
\hline & & $\begin{array}{c}\text { Entre } \\
\text { fragmentos }\end{array}$ & $\begin{array}{l}\text { Dentro do } \\
\text { fragmento }\end{array}$ & \\
\hline $5212^{*}$ & $5200 *$ & $\begin{array}{c}2100 \\
a \\
7123\end{array}$ & $\begin{array}{c}60 \\
a \\
3700\end{array}$ & 3,51 \\
\hline
\end{tabular}

As referências na literatura a respeito da distância de fluxo, principalmente de pólen, se referem principalmente à polinização pôr insetos, sendo que dados a respeito da polinização e conseqüente fluxo gênico via pólen pôr animais, para espécies arbóreas tropicais, ainda são escassos.

Crestana \& Mariano (1985) estudou a biologia floral de Hymenaea stilbocarpa Hayne, detectando sindrome de quiropterofilia. A mesma autora verificou a sobreposição de visitantes diurnos e noturnos às flores, detectando que também os beija-flores e eventualmente alguns insetos podem exercer ação polinizadora a mesma autora comenta sobre o caráter primitivo da quiropterofilia do gênero Hymenaea e afirma que a sindrome de quiropteria ocorreria nas treze espécies do gênero.

Gibbs et al 1991 estudando o sistema de cruzamento em $\mathrm{H}$. stignocarpa identificaram pelo menos 4 (quatro) espécies de morcegos, um nectívoro especializado e outros dois frugívoros como efetivos visitante e potenciais polinizadores da espécie. No mesmo trabalho os autores realizaram polinização controlada, diagnosticando que 
a espécie possui indicativos de mecanismos que privilegiam a alogamia, o que se confiram pelos resultados dos parâmetros genéticos encontrados no presente trabalho.

Gibbs et al 1991 descrevem o comportamento dos morcegos identificados como polizadores: Glossophaga soricina, Platyrhinus lineatus, Corollia perspicillata, phyllostomus hastatus, onde os mesmos foram observados forrageando durante a noite em pequenos bandos e sozinhos se alimentando de néctar e de pólen. $O$ autor também observou uma outra espécie de frugívoro maior que os descritos, mas que efetivamente visitou as flores que comparado aos outros frugivoros observados e mais especializados permaneceu mais tempo em cada flor visitada e visitou menos flores. Isso pode ser um indicativo dos resultados do maior sucesso reprodutivo de alguns indivíduos ( uma pai para várias progênies) no presente trabalho.

As informações a respeito da biologia e comportamento dos eventuais polinizadores têm diversas implicações quando se estuda os efeitos da fragmentação. Nesses estudo onde foram obtidos diversos parâmetros genéticos que permitem inferir sobre a estrutura das populações, assim como a especificidade do sistema reprodutivo , possibilitando calcular taxas de cruzamento e intensidade de trocas alélicas (fluxo gênico)

O conhecimento dos polinizadores é muito importante. $O$ aspecto da conectividade entre ambientes fragmentados tem entre um dos principais pontos a questão do fluxo gênico entre as populações contidas nessas áreas. No caso especifico do jatobá na paisagem do Pontal do Paranapanema é possivel cogitar, levando-se em conta que os polinizadores da espécie são morcegos e que esses animais são capazes de visitar diversas áreas, relativamente distantes (vários kilômetros) em uma mesma noite, isso possibilitaria o fluxo gênico entre populações fragmentadas. Esse comportamento pode explicar a baixa divergência alélica encontrada entre as populações estudadas. No entanto, é preciso enfatizar que possivelmente a estrutura encontrada nas populações analisadas são reflexo da estrutura existentes anteriormente ao processo de fragmentação quando se considera as comparações entre os adultos analisados, sugerindo a hipótese de uma baixa divergência entre populações, mantendo grandes tamanhos populacionais com pouco estrutura genética, devido à grande capacidade de vôo dos morcegos. 
A determinação do padrão de uso do espaço e de deslocamento de uma população é um ponto fundamental na genética da conservação, pois permite o entendimento da propagação dos genes entre populações através da dispersão dos indivíduos ( Wright, 1946), além de manter o pool gênico e evitar o esgotamento de recursos locais (Taylor, 1993). Os movimentos também podem ser considerados como características das espécies, tendo implicações na dinâmica populacional e na estrutura de comunidades. A obstrução dos movimentos poderia levar a extinções locais através dos processos anteriormente discutidos, devido à redução do fluxo gênico. 


\section{CONCLUSÕES}

Se comparados com outros estudos de estrutura genética de populações, sistema reprodutivo e paternidade(Gaiotto, 2001), os 05 locos SSR usados nas análises genéticas efetuadas nesse estudo foram suficientes para responder às perguntas requeridas pela hipótese de trabalho. Foram detectados níveis elevados de diversidade alélica nas populações analisadas de Hymenaea courbaril L., confirmando o elevado conteúdo de informação genética esperado para esse tipo de marcador. assim como uma alta divergência genética dentro da população (metapopulação), como esperado, para uma espécie alogama, longeva e com fluxo gênico à longa distância.

Ao se fazer a análise de paternidade de progênies provenientes de todos os indivíduos adultos da população Sumida, todos os progenitores maternos são conhecidos. A identificação dos prováveis pais permitiu que se obtivesse a distância do fluxo gênico existente entre as populações estudadas (PEMD, Alcídia e Sumida) com grande precisão.

O nivel de diversidade genética em populações é determinado pelo resultado da ação conjunta da seleção natural, da deriva genética e do fluxo gênico. A deriva genética é uma flutuação aleatória na freqüência alélica, levando à perda ou a fixação do alelo. Em populações isoladas o processo de deriva torna-se mais importante e mais rápido, devido à redução do tamanho populacional e do fluxo gênico, podendo resultar em dois casos: na perda de variação genética dentro das populações ou na divergência genética interpopulacional (Futuyma, 1992). No caso das populações alvos deste estudo, as mesmas ainda não apresentam sinais claros de divergência em função do relativo pouco tempo da fragmentação das áreas de estudo. Tomando-se 
como base os parâmetors genéticos, onde evidencia-se a existência de fluxo gênico entre as populações amostradas e não se detectou estruturação dentro das populações contidas nos fragmentos analisados, o que pode a ausência de adultos regenerantes após a fragmentação. merce destque neste trabalho o fato do tamnho efetivo $(\mathrm{Ne})$ estimado para a população Sumida ter sido maior do que o número de indivíduos $(\mathrm{N})$, permitindo sugerir que possa estar havendo uma possível "deriva genética entrópica" tendo em vista que a área é alvo de intensa pertubação.

Os dados obtidos neste estudo se referem ao estudo de populações que não podem ser consideradas representativas da paisagem local. Ao se considerar que já foram mapeados cerca de 345 fragmentos florestais na região do Pontal do Paranapanema (Ditti , 2001) e que, desse total, 13 fragmentos possuem área superior a 300 ha $(3,8 \%)$, 27 fragmentos possuem área entre 100 e 300 há $(7,8 \%)$ e 305 (88 $\%)$ fragmentos possuem área menor que 100 há sendo a maior parte entre 5 e 50 ha. Porém, numa análise mais abrangente, acredita-se que os fragmentos estudados sejam amostras de fragmentos médios (Sumida - < que $1000 \mathrm{ha}$ ) e grandes (Alcídia > qoe 1000 ha).

A análise da estruturação genética de populações de espécies arbóreas raras, dentro deste contexto, pode servir como indicativo de como fundamentar possíveis medidas de manejo dos fragmentos e da paisagem. Tendo em vista que as populações contidas em áreas "médias e grandes", como é o caso dos fragmentos objeto deste estudo, seriam um indicativo de onde possivelmente poderiam estar parindo os propágulos, visando garantir a existência de um minimo de variabilidade genética nessas populações, considerando esses fragmentos como fontes de propágulos.

As populações analisadas neste estudo refletem em parte a estrutura do passado, onde a análise dos indivíduos adultos representa uma parte da diversidade existente antes do processo de fragmentação. Ao mesmo tempo ao quantificar as taxas de fluxo gênico, seja através de medidas indiretas ( $F$ st) seja pela análise de paternidade, se tem uma visão da dinâmica atual dentro e entre as populações. a partir disso pode-se inferir sobre as possíveis conseqüências da estruturação dessas populações na paisagem. 
Assim, pode-se colocar que, apesar de algumas populações pequenas de jatobá estarem isoladas nos fragmentos, o potencial de fluxo gênico via pólen e mesmo sementes, pode minimizar possíveis efeitos de deriva genética e da endogamia. Cabe ressaltar que os valores obtidos para fluxo gênico por diferentes métodos (Fst e análise de patrnidade) tem de ser avaliados com cautela. Os valores obtidos pelas etimativas de fluxo gênico aperente refletem uma análise de eventos do passado e que de fato ocorreram. As análises diretas por via de probabilidade e exclusão de paternidade via pólen referem-se à movimentação de gametas que deram origem a propágulos que não necessáriamente virão a ser recrutados e efetivamente fazer parte do pool gênico das populações.

Sendo assim, as escalas de espaço de tempo são fatores bastante relevantes que nunca devem ser desconsiderados. Com relação à escala de tempo, amostras instantâneas não permitem a compreensão das dinâmicas populacionais, podendo revelar apenas frações de metapopulações. A escala de espaço gera uma controvércia no que se a tamanhos de "reservas "que contenham populações viáveis. As opiniões divergem entre a importância de grandes reserva as quais, aumentariam as chances de sobrevivência de determinadas espécies, resultando em menores taxas de extinção, por outro lado, alguns autores ressaltam que muitas reservas de tamanhos pequenos favoreceriam maior número de espécies e espécies de borda que vivem nas interfaces de habitats (Diamond, 1976)

Metapopulações formam uma categoria delimitada dentro de um contínuo de respostas possiveis à fragmentação, que vai de uma única população até as chamadas populações relictuais. Num habitat fragmentado,considerado um extremo, os indivíduos podem deslocar-se entre fragmentos com a mesma facilidade que dentro de cada fragmento; nesse caso, na verdade há uma única população da espécie em questão. No caso intermediário, os indivíduos movem-se livremente dentro dos fragmentos, mas o movimento entre os fragmentos é mais difícil, embora não impossível. Temos, então, um conjunto de populações bem diferenciadas, porém conectadas, que vem a ser uma metapopulação. No outro extremo, o fluxo de individuos entre fragmentos é impossivel e nesse sistema de populações só podem ser perdidas, via extinção local, neste caso as populações podem ser denominadas relictuais. No estudo de caso deste estudo, 0 
jatobá no Pontal do Paranapanema, acredita-se que o segundo caso se enquadre melhor dentro da realidade da paisagem local.

Para a biologia e genética da conservação é importante poder predizer se, e por quanto tempo, uma determinada espécie estruturada em metapopulação irá persistir em escala regional. Os modelos de dinâmica de metapopulações apresentados são por demais genéricos e incapazes desse tipo de predição. Modelos preditivos para determinada espécie em determinado ambiente fragmentado devem levar em consideração a distribuição espacial das manchas de habitats, a localização e o grau de isolamento dos fragmentos .Para espécies arbóreas muito longevas, tal como o jatobá, essa predição fica mais difícil de ser conservada.

O estudo dos diversos aspectos da fragmentação, nesse caso específico a análise de parâmetros de genética remete par a necessidade de se restaurar ambientes fragmentados o que segundo Metgzer (no prelo) cria uma noção antagônica ente fragmentação e conectividade, onde a restauração ou efetivação da conectividade se constitui na medida efetiva de manejo.

Os dados do presente estudo demonstram que para as áreas estudadas a noção de conectividade é de suma importância, quando se considera que a mesma se define como a capacidade de uma paisagem de facilitar os fluxos de organismos, sementes e grãos de pólen. $O$ aspectos funcional dessa abordagem refere-se à resposta biológica específica de cada espécie à estrutura da paisagem (Metgzer, no prelo). Somente o acúmulo de informaçōes sobre diferentes grupos de espécies, poderá permitir apontar direções mais sutentáveis para o manejo dos fragmentos da paisagem.

A análise dos dados na paisagem onde se efetuou este estudo demonstra que estruturalmente/fisicamente seria possível inferir sobre a desrruptura da continuidade das matas e sobre a influência da mesma no fluxo gênico entre as espécies nesse caso do Jatobá. Porém, pode-se apontar processos que devem estar ocorrendo com as populações de jatobá no Pontal do Paranapanema, e sugerir direções para o manejo das populações na paisagem. 
O aumento da permeabilidade da paisagem, a efetivação dos corredores (diversas categorias) e a proteção efetiva dos fragmentos florestais em linhas gerais seriam medidas de manejo da paisagem no Pontal do Paranapanema. 


\section{REFERÊNCIAS BIBLIOGRÁFICAS}

ALVAREZ-BUYLLA, E.R.; GARAY, A. A Population genetic structure of Cecropia obtusifolia, a tropical pioneer species. Evolution, v.48, n.2, p.437-453, 1994.

ALVAREZ-BUYLLA, E.R.; CHAOS, A.; PIÑERO, D.; GARAY, A. A Demographic genetics of a pioneer tropical tree species: patch dynamics, seed dispersal and seed banks. Evolution, v. 50, n.3, p.1155-1165, 1996.

ALLENDORF, F.W.. Isolation, gene flow and genetic differentiation among populations. Em Schonewald-Cox, C.M.; S.M. Chambers; B. McBryde \& W.L. Thomas (Eds.). Genetics and Conservation. The Benjamin / Cummings Publishing Company, Menlo Park, California. 1983.

AMARAL, P.; VERISSIMO, A.; BARRETO, P. VIDAL, E. Floresta para sempre: Um manual para a produção de madeira na Amazônia. Belém: IMAZON, 1998. 137p.

BAITELLO, J.B.; AGUIAR, O.T. Flora arbórea da Serra da Cantareira (São Paulo). Silvicultura em São Paulo, v.16 A, n.1, p.582-590. 1988.

BARRETT, S.C.H.; KOHN, J.R. Genetic and evolutionary consequences of small population size in plants: implications for conservation. In: FALK, D.A.; HOLSINGER, K.E. (Ed) Genetics and conservation of rare plants. Oxford: Oxford University Press, 1991. p.3-30.

BAWA, K.S. Breeding systemas of tree species of a lowland tropical community. Evolution, v.28, p.85-92. 1974

BAWA, K.S.; WEBB, C.J. Flower, fruit and seed abortion in tropical forest trees: implications for the evolution of paternal and maternal reproductive patterns. American Journal of Botany, v.71, n.5, p.736-751. 1984. 
BIERREGAARD Jr., R.O.; LOVEJOY, T., KAPOS, V.; SANTOS, A dos.; HUTCHINGS, R. The biological dynamics of tropical rainforest fragments - a perspective comparison of forest fragments and continuous forest. BioScience, v.42, p.859866, 1992.

BOSHIER, D.H.; CHASE, M.R.; BAWA, K.S. Population genetics of Cordia alliodora (Boraginaceae), a neotropical tree. 3. Gene flow, neighborhood, and population structure. American Journal of Botany, v.82, n.4, p.484-490, 1995.

BRISOLA, L.M.L. Estudo do hábito alimentar de Tapirus terrestris (Lineu, 1778, Ordem Perissodactyla) e sua atuação como dispersor de sementes no Parque Estadual do Morro do Diabo. B. Sc. Rio Claro, UNESP, 1989.

CIAMPI, A.Y. Desenvolvimento e utilização de marcadores microsatélites, AFLP e sequnciamento de cpDNA, no estudo da estrutura genética e parentesco em pópulações de copaíba (Copaifera langsdorfii) em matas de galeria no cerrado. Botucatu, 1999. 204p. Tese (Doutorado) - Instituto de Biociências. Universidade Estadual Paulista "Julio de Mesquita Filho".

COCKERHAM, C.C. Variance of gene frequencies. Evolution, v.23, p.72-84, 1969.

COLLEVATTI, R.G.; GRATTAPAGLIA, D.; HAY, J.D. Population genetic structure of the endangered tropical tree species Caryocar brasiliensis based variability and microsatellite loci. Molecullar Ecology, 2001. /No prelo/

CONSERVATION INTERNATIONAL DO BRASIL; FUNDAÇÃO SOS MATA ATLÂNTICA; FUNDAÇÃO BIODIVERSITAS; INSTITUTO DE PESQUISAS ECOLÓGICAS; SECRETARIA DO MEIO AMBIENTE DO ESTADO DE SÃO PAULO; INSTITUTO ESTADUAL DE FLORESTAS - MG. Avaliação e ações prioritárias para a conservação da biodiversidade dos biomas mata atlântica e campos sulinos. Brasília: Probio - Ministério do Meio Ambiente, 2000. 
COSTA. L.G.S. Estrutura e dinâmica de techo de mata mesófila semidecidua, na Estação Ecológica de Ibicatú, Piracicaba-SP. Disseratação de Mestrado, Instituto de Biociências, Usp. 1992.

CRESTANA, C.S.M.; MARIANO, I.S Ecologia da polinização de Hymenaea stilbocarpa Hayne, o Jatobá. Silvicultura em São Paulo, v.17/19, p.31-37, 1985.

CROW, J.P.; KIMURA, M. An introdution to population genetics theory. New York: Haveper and Row, cap 07,p.56-62, 1970.

CULLEN, L.; VALLADARES-PÁDUA,C. Pontal do Paranapanema: reforma agrária com conservação da biodiversidade. (no prelo)

DEAN, W. A ferro e fogo: a história e a devastação da Mata Attântica Brasileira. São Paulo: Companhia das Letras, p.34-57, 1996.

DEVLIN, b.;ELLSTRND, N.C. The development and application of a refined method for estimating gene flow from angiosperm patrnity analysis. Evolution, v.44,n.2,p. 248-259, 1990.

DIAMOND, J.M. Island biogeography and conservation: strategy and limitations. Science, v.193, p.1027-1029, 1976.

DITT. E.H., Diagnóstico da conservação e das ameaças a fragmentos florestais no Pontal do Paranapanema, São Paulo. Disseratção (Mestrado) PROCAM Universidade de São Paulo, p.97, 2000.

ELLSTRAND, N.C.; ELAN, D.R. Population genetic consequences of small population size: implications for plant conservation. Annual Review of Ecology and Systematics, v.245, p.217-42, 1993.

ESTRADA, A.; COATES-ESTRADA, R.; MERITT JR., D.; MONTIERL, S.; CURIEL, D.. Patterns of frugivore species richness and abundance in forest ilslands and in agricultural habitats at Los Tuxtlas, Mexico. Vegetatio, v.107/108, p.245-257, 1993. 
FERRARI-LEITE, J. A ocupação do Pontal do Paranapanema. São Paulo: Editora Hucitec, 1998. 111p.

FORMAN, R.T.T. Corridors in a landscape: their ecological structure na function. Ecology, v.2, p.375-387, 1983.

FORMAN, R.T.T. Some general principles of landscape and regional ecology. Landscape Ecology, v.10, p.133-142, 1995.

FORMAN, R.T.T.; BAUDRY, J. Hedgerows and hedgerow networks in Landscape Ecology and Environmental Management., v.8, p.495-510, 1984.

FORMAN, R.T.T.; GODRON, M. Landscape Ecology. New York:John Wiley. v16, p 712, 1986.

FORMAN, R.T.T., GALLI, A.E.; LECK, C.F. Forest size and avian diversity in New Jersey woodlots with some land use implications. Oecologia, v.26, p.1-8. 1976.

FORÉ, S.a; HICHEY, R.J.; VANKAT, J.L. ET AL. Genetc structure afte forest fragmentation: na landscape ecology perspective on Acer saccharum. Canadian Journal of Botany, v.70, p. 165-168, 1992.

FUTUYMA, D.J. Biologia Evolutiva. Ribeirão Preto: Sociedade Brasileira de Genética, 1992, 631p.

GAIOTTO, F.A. Inferências sobre herança quantitativa e estrutura genética em populações naturais de Euterpe edulis Mart. Utilizando marcadores microsatélites. Piracicaba, 2001. 122p. Tese (Doutorado) - Escola Superior de Agricultura Luiz de Queiroz. Universidade São Paulo.

GANDARA, F.B. Diversidade genética, taxa de cruzamento e estrutura espacial dos genótipos em uma população de Cedrella fissilis Vell. (Meliaceae). Piracicaba, 1996, 96p. Tese (Mestrado ) - Escola Superior de Agricultura Luiz de Queiroz. Universidade de São Paulo. 
GENTILE, R. \& R. Cerqueira (1995). Movement patterns of five species os small mammals in a Brazilian Restinga. J. Trop. Ecol., 11: 671-677.

GILPIN, M; HANSKI, I (Ed.) Metapopulation dynamics: empirical and theoretical investigations. London: Academic Press, 1991.

GOVINDARAJU, D.R. Relationship between dispersal ability and levels of gene flow in plants. Oikos, v.52, p.31-35, 1988.

GRANT, V. Gene flow and the homogeneity of species populations. Biologisches Zentralblatt, v.99, p.157-169, 1980.

HAMRICK, J.L.; LOVELESS, M.D. The genetic structure of tropical tree populations: associations with reprodutive biology. In: BOCK, J.H.; LINHART, Y.B. (Ed.) The evolutionary ecology of plants. Boulder: Westview Press, 1998. p.129-146.

HAMRICK, J.L..; GODT, M.J.W.; SHERMAN-BROYLES, S.L. Factors influencing levels of genetic diversity in wood plant species. New Forest, v.6, p.95-124, 1992.

HAMRICK, J.L.; GODT, M.J.W.; SHERMAN-BROYLES, S.L. Factors influencing levels of genetic diversity in wood plant species. New Forest, v.6, p.95-124, 1992.

HAMRICK, J.L.; MURAWSKI, D.A.; NASON, J.D. The influence of tropical trees: procesures and preliminary results. Biotropica, v.18, n.3, p.2001-207, 1986.

HAMRICK, J L.; MURAWSKI, D.A.; NASON, J.D. The influence of seed dispersal mechanisms on the genetic structure of tree populations. Vegetation, v.107/108, p.281-297, 1993.

HANSKI, I. Single species metapopulation dynamics. In: GILPIN, M. ; HANSKI, I. (Eds.) Metapopulation dynamics: empirical and theoretical investigations. London: Academic Press, 1991. p.17-38.

HANSKI, I. Spatial scale, Patchiness and Population Dynamics on Land. Philosophical Transactions of Royal Society of London. v.343, p.19-25, 1994. 
HANSKI, I. Predictive and pratical metapopulation models: the incidence function approach. In: TILMAN, D.; KAREIVA, P. (Ed.), Spatial ecology: the role of space in population dynamics and interspecific interactions. New Jersey: Princeton University Press, 1997, p.21-45.

HARRISON, R.L. Toward a theory of inter-refuge corridor design. Conservation Biology, v.6, p.293-295, 1992.

HARRISON, S. Local extintion in a metapopulation context: na empirical evaluation. In: GILPIN, M. ; HANSKI, I. (Eds.) Metapopulation dynamics: empirical and theoretical investigations. London: Academic Press, 1991. p.73-88.

HILL, M.F.; CASWELL, H. Habitat fragmentation and extinction thresholds on fractal landscapes. Ecology Letters, v.2, p.121-127, 1999.

HOBBS, E.R. Species richness of urban forest patches and implications for urban landscape diversity. Landscape Ecology, v.1, p.141-152. 1988.

INSTITUTO NACIONAL DA REFORMA AGRÁRIA (INCRA) Recadastramento: metodologia de levantamento e processamento de informações cadastrais georreferenciadas. Brasília: Gabinete do Ministro Extraordinário de Politica Fundiária, 1997.p.95.

JANZEN, D.H. Digestive seed predation by a Costa Rican Bairds'Tapir. Biotropica, v.13, p.59-63, 1981.

KAGEYAMA, P.Y; GANDARA, F.B. Dinâmica de populações de espécies arbóreas: implicações para o manejo e a conservação. In: SIMPÓSIO DE ECOSSITEMAS DA COSTA BRASILEIRA: SUBSIDOS A UM GERENCIAMENTO AMBIENTAL, 3, Serra Negra, São Paulo: ACIESP,1994.Vol.2, p.17-24.

KAGEYAMA, P.Y; GANDARA, F.B.; Conseguências genéticas da fragmentação sobre populações de espécies arbóreas. In: SIMPÓSIO BRASILEIRO SOBRE FRAGMENTAÇÃO FLORESTAL, Piracicaba, 1999. Anais. Piracicaba: IPEF. 1999. p. 53-56. 
KAPOS, V. Effects of isolation on the water status of forest patches in the Brazilian Amazon. Journal of Tropical Ecology, v.5, p.173-195. 1989.

KRONKA, F.J.N.; MATSUKUMA, C.K.; NALON, M.A.; CALI, I.H.D.; ROSSI,M.; MATTOS, I.F.; SHIN-IKE, M.S.; PONTINHAS, A.A.S. Inventário Florestal Do Estado De São Paulo: Instituto Florestal, Secretaria do Meio Ambiente São Paulo,. 1993.

LEE, Y.T. \& J.H. LANGENHEIM. 1975. Systematics of the genus Hymenaea I. (Leguminosae, Caesalpinioideae, Detarieae). Univ. California Publ. Bot. 69:1-109.

LEITÃO-FILHO, H.F. A vegetação In: LEITÃO-FILHO, H.F.; MORELLATO, L.P. (Eds.) Ecologia e preservação de uma floresta tropical urbana : Reserva de Santa Genebra. Campinas: Editora da UNICAMP, 1995, p.19-29.

LEPSCH-CUNHA, N. I. Variabilidade genética de duas espécies de baixa densidade na Amazônia Central: Couratari multiflora (J. E. Smith) Eyma e Couratari guianensis Aublet. II. Fenologia e sistema reprodutivo de Couratari multiflora (J. E. Smith) Eyma. Piracicaba, 1996. 131p. Tese (Mestrado) - Escola Superior de Agricultura Luiz de Queiroz. Universidade de São Paulo.

LEVINS, S. A. Some demographic and genetic consequences of environmental heterogeneity for biological contrrol. Bulletim of Entomological Society of America, ., v.15, p.237-240, 1969.

LEVINS, S. A. Dispersion and population interactions. American Naturalist, v.108, p.207-228, 1974.

LEVINS, S. R. Extinction. In: GERSTENHABER, M. (Ed.), Some mathematical Questions in Biology. Rhode Island: American Mathematical Society, 1970. p.77107.

LEWIS, p.; ZAYKIN, D. Genectic data aanalysis: versão 2 para windows 3.1. 2000. (não publicado). 
LITT M, LUTTY J.A (1989) A hypervariable microssatellite revealed by in vitro amplification of a dinucleotide repeat within the cadic muscle actian gene. American ljournal of Human Genetics 444:397-401.

LORD, J.M.; NORTTON, D.A. Scale and the spatial concept of fragmentation. Conservation Biology, v.4, p.197-202. 1990.

MACARTHUR, R.H.; WILSON. E.O. The theory of island biogeography. Princeton: Princeton University Press. Ed. 1967.

MALCOLM, J.R.. The small mammals of amazonian forest fragments: pattern and process.PhD.Thesis.University.of.Florida.,(1991)

MALTEZ, H.M. Estrutura genética de Aspidosperma polyneuron Muell. Arg apocynaceae (peroba rosa) em uma floresta estacional semidecidual no Estado de São Paulo. Campinas, 1997. 132p. Tese (Mestrado) - Instituto de Biologia, Universidade Estadual de Campinas.

MCCULLOUGH, D.R. Metapopulation and wildlife conservation. Washington: Island Press, 1996.

MERRIAN, G. Connectivity: a fundamental ecological characteristic of landscape pattern. In: BRANDT, J.; AGGER, P. (Eds.), INTERNATIONAL SEMINAR ON METHODOLOGY IN LANDSCAPE ECOLOGICAL RESEARCH AND PLANNING, 1, Proceedings, Roskilde: International Association for Landscape Ecology, 1984., p. 5-15.

METZGER, J.P. Structure du paysage et dioversité des peuplements lineux fragmentés durio Jacaré-Pepira (Sud-Est du Brésil). Toulouse, 1995, Mesis(PL.D) Université Paul Dabatier.

METZGER, J.P.; MULLER, E. Characterizing the complexity of landscape boundaries by remote sensing. Landscape Ecology, v.11, p.65-77, 1996. 
METZGER, J.P.; DÉCAMPS, H. The structural connectivity threshold: an hypothesis in conservation biology at the landscape scale. Acta CEcologica, v.18, p.1-12. 1997.

METZGER, J.P. Estrutura da paisagem e fragmentação: análise bibliográfica. Anais da Academia Brasileira de Ciências.V.71,n.3, p..., 1999

METZGER, J.P. Relationships between landscape structure and tree species diversity in tropical forests of South-East Brazil. Landscape and Urban Planning. v.37, p.29-35. 1997.

METZGER, J.P., GOLDENBERG, R.; BERNACCI, L.C. Diversidade e estrutura de fragmentos de mata de várzea e de mata mesófila semidecídua submontana do rio Jacaré-Pepira (SP). Revista Brasileira de Botânica, v.21, p.321-330, 1998.

MORELLATO, L.P.C. Estudo da fenologia de árvores, arbustos e lianas de uma floresta semidecidua no sudeste do Brasil. Campinas, 1991. 176p. Tese (Doutorado) - Universidade Estadual de Campinas.

NILSSON, S.G.; NILSSON, I.N. Species richness and dispersal of vascular plants to islands in lake Möckeln, Southern Sweden. Ecology, v.59, p.473-480, 1978.

NOSS, R.F. Corridors in real landscapes: a reply to Simberloff and Cox. Conservation Biology, v.1, p.159-164,1987.

O'MALLEY, D.M.; BUCKLEY, D.P.; PRANCE, G.T.; BAWA, K.S. Genetics of Brazil nut (Bertholettia excelsa Humb. \& Bonpl.: Lecythidaceae). 2. Mating system. Theoretical and Applied Genetics, v.76, p.929-932, 1988.

OPDAM, P. Metapopulation theory and habitat fragmentation: a review of holarctic breeding bird studies. Landscape Ecology, v.5, p.93-106, 1991.

OPDAM, P., VAN APELDOORN, R., SCHOTMAN, A.; KALKHOVEN, J. Population responses to landscape fragmentation. In: VOS, C.C. \& OPDAM, P. (Ed.), Landscape ecology of a stressed environment. London: Chapman \& Hall, 1993. p.147-171. 
OYAMA, K. Conservation Biology of tropical trees: demographic and genetic considerations. Environment update, v.1, p.17-32, 1993.

PERECIN, B. Diversidade genética em populações naturais de espécies de espinheira santa, Maytenus aquifolia Mart. E M. ilicifolia Mart. Ex Reiss. Piracicaba, 2000. 134p. Tese (Doutorado) - Escola Superior de Agricultura " luis de Queiroz" , Universidade de São Paulo.

REDFORD, K.H. A floresta vazia. In: VALLADARES- PÁDUA, C.; CULLEN-JR, L.; BODMER, R. (Orgs). Manejo e Conservação da Vida Silvestre no Brasil. Brasília: MCT-CNPq/ Sociedade Civil Mamirauá, 1997. p 05-11.

REIS, M.S. Distribuição e dinâmica da variabilidade genética em população naturais de palmiteiro (Euterpes edulis M.). Piracicaba, 1996. 82 p. Tese(Doutorado) - Escola Superior de Agricultura Luiz de Queiroz. Universidade de São Paulo.

RITLAND, K.; EL-KASSABY, Y.A. The nature of inbreeding in a seed orchad of douglas fir as shown by na efficient multilocus model. Theorical and Applied Genetics, v.71, p. 375-384,1985.

RITLAND, K A series of fortran computer programs for estimating plant mating systems. Jornal of Heredity, v.81, p.235-237, 1990.

RIZZINI, C.T. Árvores e madeiras uteis do Brasil: manual de dendrologia brasileira. São Paulo: Edgard \& Blücher, 1971. 294p.

ROLSTAD, J. Consequences of forest fragmentation for the dynamics of bird populations: conceptual issues and the evidence. Biological Journal - Linnean Society, v.41, p.149-163, 1991

ROSS, J. Análise empirica de fragilidade dos ambientes naturais e antropizados. Revista do Departamento de Geografia FFLCH/USP, v.8, p.63-74. 1994.

ROSS, J.L.S.; MOROZ, I.C. Mapa geomorfológico do Estado de São Paulo, São Paulo: IPT, 1997. Escala 1:500.000 
SANTOS, P.S. Fragmentação de habitats: implicações para a conservação in situ. In: ESTEVES, F.A. (Ed.). Oecologia brasiliensis. 616 p, 1995.

SAUNDERS, D.A.; DE REBEIRA, C.P. Values of corridors to avian population in fragmented landscape. In: SAUNDERS, D.A.; HOBBS, R.J. (Ed.), Nature conservation 2: the role of corridors. New South Wales: Surrey Beatty, 1991. p. 221-240.

SAUNDERS, D.A.; HOBBS, R.J. The role of corridors in conservation: what do we know and where do we go? In: SAUNDERS, D.A.; HOBBS, R.J. (Ed.), Nature conservation 2: the role of corridors. New South Wales: Surrey Beatty, 1991. p.421-427.

SAUNDERS, D.A.; HOBBS, R.J.; MARGULES, C.R. Biological consequences of ecosystem fragmentation: a review. Conservation Biology, v.5, p.18-32, 1991.

SCHLITTLER, F.H.M. Floística e fitossocologia da reserva do Morro do Diabo. Rio Claro-SP, 1990. 279p. Tese (Doutorado) - instituto de Biociências/ Univerdade Estadual Paulinia.

SEOANE, C.E.S. Efeitos da fragmentação florestal em populações de Esenbeckia leiocarpa (Guarantã) - Um exemplo de espécie tropical arbórea climácica de distribuição agregada. Campinas-1998. 80p Dissertação (Mestrado em Ciências) Instituto de Biologia, Universidade Estadual de Campinas.

SIMBERLOFF, D. Flagships, umbrellas, and keystones: is single-species management passé in the landscape era ? Biological Conservation, v.83, p.247-257, 1998.

SIMBERLOFF, D.; FARR, J.; COX, J.; MEHLMAN, D.W. Movement corridors: conservation bargains or poor investiments? Conservation Biology, v.6, p.493$504,1992$.

SLATKIN, M. Gene flow in natural populations. Annual Review of in Ecology and Systematics, v.16, p.393-430, 1985.

SLATKIN, M. Rare alleles as indicators of gene flow. Evolution, v.39, p.53-65, 1985. 
SOULÉ, M.E.; GILPIN, M.E. 1991. The theory of wildlife corridor capability. In: SAUNDERS, D.A.; HOBBS, R.J. (Ed), Nature conservation 2: the role of corridors. New South Wales: Surrey Beatty, 1991. p.3-8.

SOUZA, L.M.F.I. Estrutura genética de populações naturais de Chorisia speciosa St.Hill. (Bombacaceae) em fragmentos florestais na região de Bauru (SP) - Brasil. Piracicaba, 1997. 76p. Tese (Mestrado) - Escola Superior de Agricultura Luiz de Queiroz, Universidade de São Paulo.

STACY, E. A; HAMRICK,J.L.; NASON,D.; HUBBELL, S.P.; FOSTER,R.B.; CONDIT,R. Pollen dispersal in low-density populations of three neotropical tree species. The American Naturalist, v.148, n.2, p.275-298, 1996.

TAUTZ D., RENZ M. (1994) Simple sequences are ubiquitous repetitive components of eukaryotic genomes. Nucleic Acids Res. 12:4127-4138.

TAYLOR, P.D.; FAHRIG, L.; HENEIN, K.; MERRIAM, G. Connectivity is a vital element of landscape structure. Oikos, v.68, p.571-573, 1993.

TEMPLE, S.A. Predicting impacts of habitat fragmentation on forest birds: a comparison of two models. In: VERNER, M.L., MORRISSON, M.L.; RALPH, C.J. (Ed), Wildlife 2000: modeling habitat relationships of terrestrial vertebrates. Madison: The University of Wisconsin Press, 1986. p. 301-304.

TERBORGH, J. Keystone plant resource in the tropical forest. In: SOULÉ, M. Conservation biology: an evolucionary - ecologycal perspective. Suderlands: Sinauer Associates, 1980. p.151-169.

TERBORGH, J. Island biogeography and conservation: strategy and limitations. Science, v.193, p.1029-1030. 1976.

TURNER, M. G. Landscape ecology: the effect of pattern on process. Annual Review of Ecology and Systematics, v.20, p.171-197.,1989.

TERBORGH, J. The role of felid predators in neotropical forests. Vida Silvestre Tropical, v.2, n.2, p.3-5, 1990. 
URBAN, D.L.; SHUGART, H.H. JR. Avian demography in mosaic landscapes: modeling paradigm and preliminary. In: VERNER, M.L., MORRISSON, M.L. \& RALPH, C.J. (Ed), Wildlife 2000: Modeling habitat relationships of terrestrial vertebrates. Madison: The University of Wisconsin Press, 1986. p.273-279.

VALLADARES-PÁDUA, C.; CULLEN, L. Distribution, abundance and minimum viable metapopulation of the black lion tamarin, Leontophitecus chrysopygus. Dodo. J. Wildl. Preserv. Trusts, v.30, p.80-88 1994.

VAN DORP, D.; OPDAM, P.F.M. Effects of patch size, isolation and regional abundance on forest bird communities. Landscape Ecology, v.1, p.59-73, 1987.

VELOSO. H.P; RANGEL-FILHO, A.L; LIMA, J.C.A. Classificação da Vegatação Brasileira, Adapatada a um sistema Universal. Rio de Janeiro: Fundação Instituto Brsilerio de Geografia e Estatistica - IBGE, 1991.

VENCOVSKY, R. Variance of an Estimate of Outcrossing Rate. Revista Brasileira de Genética, v.17, n.3, p.349-51. 1994.

VIANA, V.M., TABANEZ, A.A.J.; BATISTA, J.L. Dynamic and restoration of forest fragments in the Brazilian Atlantic moist forest. In: LAURANCE, $W$; BIERREGAARD, R., JR. (Eds.), Tropical forest remnants: ecology, management, and conservation of fragmented communities. Chicago: The University of Chicago Press, 1997. p.351- 365.

WHITCOMB, R.F.; LYNCH, J.F.; OPLER, P.A.; ROBBINS, C.S. Island biogeography and conservation: strategies and limitations. Science, v.193, p.1030-1032. 1976.

WILCOX, B.A. Insular ecology and conservation. In: SOULÉ, M.E.; WILCOX, B.A. (Eds.), Conservation biology: an evolutionary-ecological perspective. Sunderland: Sinauer Associates, 1980. p.95-117.

WILSON, M.F. Dispersal mode, seed shadows and colonization patterns. Vegetatio, v.107/108, p.261-280. 1993. 
WRIGHT, S. The interpretation of population structure by F-statistic with special regard to system of mating. Evolution, v.19. p.395-420. 1965.

WRIGHT, S. The interpretation of population structure by F-statistics with special regard to systems of mating. Evolution, v.19, p.395-420. 1965.

WRIGHT, S.J.; GOMPPER, M.E.; DeLEON, B. Are large predators keystone species in Neotropical forests? The evidence from Barro Colorado Island. Oikos, v.71, p.279294, 1994.

YOUNG, A.; MITCHELL, N. Microclimate and vegetation edge effects in a fragmented podocarp-broadleaf forest in New Zealand. Biological Conservation, v.67, p.63$72,1994$.

YOUNG, A; BOYLE, T.; BROWN, T. The population genetic consequences of habitat fragmentation for plants. Tree, v.11, n.10, p.413-418, 1996.

YOUNG, A; WARWICK, S.I.; M,: ERRIAM, H.G. Genetic variation and structure at three spatial acales for acer saccharum (sugar maple) in Canada and the implication for conservation. Canadian Journal of Forest Research, v.23, p.2568-2578, 1993. 